\title{
SAÚDE PÚBLICA: REPRODUÇÃO OU LEGITIMAÇÃO?
}

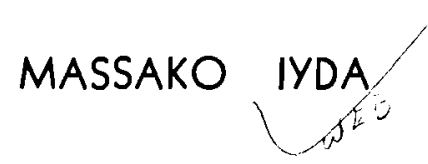

Tese apresentada à Faculdade de Saúde Pública da Universidade de São Paulo, Departamento de Epidemiologia, para obtenção do grau de Doutor em Saúde Pública.

Orientadora : Profa Dra MARIA STELLA FERREIRA LEVY

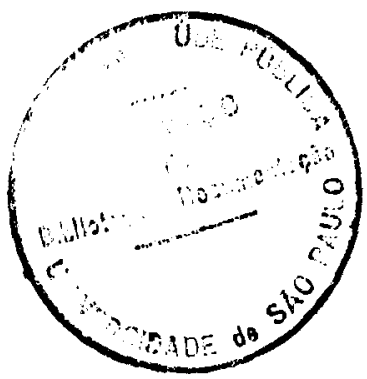


Ao clã dos Iyda

\author{
Aos ex-residentes do atual \\ Departamento de Medicí \\ na em Saúde Pública da \\ Faculdade de Medicina, \\ "Campus" de Botucatu, \\ UNESP e in memoriam de \\ Rubens Belluzo Brandão \\ (Rubão) e Rubens Maria \\ Lopes (Rubeta).
}


Na trajetōria de elaboração de um projeto e de seu desenvolvimento, há muito e muitos a agradecer. Meu reconhe cimento a todos aqueles que me concederam seu tempo, discu tindo minhas idéias iniciais, minhas dúvidas, minhas idas e vindas e, em especial a Maria Cecilia Ferro Donnangelo in memoriam.

Meus agradecimentos aqueles que, nesses anos todos, tornaram possivel a concretização do presente trabalho:

- a Maria Stella Ferreira Levy, pela orientação, mas mais do que isso pela sua atenção carinhosa e pelo estímulo sempre presentes;

- a Cecilia Magaldi, por infinitas razões, profis sionais e pessoais, entre as quais pela construção conjunta e cotidiana deste trabalho e da disciplina de Ciências So ciais Aplicadas à Saúde, desde o meu ingresso no Departamento;

- a Octávio Ianni, por ter me aceito como aluna no seu Curso de Pós-Graduação e pelos conhecimentos transmití dos, que foram essenciais para o presente trabalho e para minhas atividades didáticas;

- aos colegas do Departamento de Medicina em Saúde Pública da Faculdade de Medicina de Botucatu, a Nelson de Souza, seu chefe e, em especial, a Lupércio de Souza Cortez Jr. e Rubens Maria Lopes (in memoriam), pelas discussões que contribuiram para o trabalho; a Ione Morita e Margareth Santilli de Almeida, por terem assumido minhas atividades didáticas neste ano; a Eliana Goldfarb Cyrino, pelo reforço e apoio operacional, conjuntamente com Ione, nessa fase final;

- a Inês Gontijo Antonini e Marcello Fabiano de Franco, pela remessa de material bibliográfico e por terem 
tornado esta trajetória mais amena. Agradecimento especial a Marcello, pelo estímulo altamente criativo e produtivo e, também, pela versão para o inglēs do trabalho;

- a Isabel de Carvalho, Regina Marsiglia Giffoni e Keiko Ogura Buralli pela leitura do texto final e pelas dis cussões ;

- ao Dr. Wilson Pedro Speridião, Tullo Vigenani, Julieta Hitomi Oshiro, pelo empréstimo de material bibliográ fico e pela gentileza com que me receberam;

- a D. Kikita, Maria de Lourdes Rosa Pereira, pela revisão do português;

- a Terue Sadatsune que, com extrema paciência,con frontou textos, obrigando-se a leitura integral do texto, distante de suas leituras microbiológicas;

- a Daisy Pires Noronha, Irene Lerche Eleutério, An gela M. Belloni Cuenca e Sonia G. Gomez Eleutério, do Servi ço de Biblioteca e Documentação da Faculdade de Saúde Pública; a Ana Maria Dias, da Divisão de Documentação da Secretaria da Fazenda; a Elizabeth Haddad, da Seção de Biblioteca da Secretaria do Estado de Saúde; a Glaura M.B. Barbosa Almeida e Elza Numata, da Biblioteca do "Campus" de Botucatu, por te rem, gentilmente, facilitado a consulta do material bibliográ fico e as duas últimas pela normatização final das referências bibliográficas. Agradecimento especial a Daisy pela ama bilidade e atenção nesses anos de Pós-Graduação e pelo auxí lio na organização. das referências;

- a Eunice Solimano Serra e Jony Serra, pela datilografia de inúmeros manuscritos e relatórios; a Ana Paula va roli, pela digitação e impressão da minuta da tese e a Ivone te Aparecida Dorini de Aguiar e Silva, pela datilografia fí nal e pela gentileza;

- a Antonio Pereira Simões, Chefe do Departamento de Pediatria e a Eliana Goldfarb e Antōnio de Pádua Pithon 
Cyrino, pelas condições para impressão deste trabalho;

- a José Carlos Carreira, dos Serviços Gráficos do "Campus" de Botucatu e Paulo Henrique Ferrari, pela disponibilidade e amabilidade, na impressão e reprodução do trabaIho;

- a Ana Angel, da Seção de Pós-Graduação da Faculdade de Saúde pública, um agradecimento especial, pela sua amável atenção nesses anos de Pós-Graduação;

- a Banca Examinadora - Amélia Cohn, Cecília Magal di, Eurivaldo Sampaio de Almeida, Maria Stella F. Levy e octávio Ianni, pela leitura, discussão e sugestões, referentes à minuta da tese;

- ao Conselho Nacional de Pesquisa (CNPq), pela bolsa concedida;

- aos amigos de sempre Águeda, Chicão, Dinah, Edy, Ellen, Isamara, Norminha, Olinto, Regina, Reinaldão, Renzo, Sonia, Teruca e, muito especialmente, a Ana Teresa, Maria Ri ta e as minhas irmãs Júlia Nobuco, Lúcia Mitsué, Diva Tomoko, Laura Kazue, Ana Ioe e Irene Shizue, pelo apoio terno e incondicional. 
Este trabalho procura analisar a Saúde Pú blica como uma prática social, de relação de clas ses sociais, numa formação capitalista tardia e de pendente. Parte-se do pressuposto que o caráter de dependência dá especificidades próprias ao desenvol vimento capitalista no Brasil e à institucionaliza ção da saúde pública. Objetiva-se, especificamen te, analisar a Saúde Pública como parte integrante na constituição de um Estado burguês. A análise en globa o período de 1889 a 1978, compreendendo qua tro fases, correspondentes a rupturas políticas de regimes governamentais e está centralizada no Esta do de São Paulo. Os dados analisados demonstram que, sob o domínio português e, ainda por um longo período, as atividades de saúde ficaram sob a res ponsabilidade de associações privadas, filantrópi cas e/ou religiosas. Ao intensificar o processo de desenvolvimento capitalista e sob o impacto do impe rialismo, a Saúde Pública ganha expressão e adquire uma ārea especifica de atuação estatal, criando es tururas técnico-burocrāticas. Por meio destas, di vulgam-se idéias, estabelecem-se regras e normas legais, destinam-se recursos financeiros e, tambëm, viabilizam os diferentes interesses de classes e frações de classes, localizados dentro e fora do aparelho estatal. Os dados, ainda, demonstram que esse substrato material possibilita a sedimentação da Saúde pública como uma atividade estatal e dáthe a legitimidade para impôr-se, mesmo coercitivamente, frente à sociedade. 
The present investigation made an attempt to analyse Public Health as a social praxis, i.e., as a relationship of social classes inside a dependent capitalist framework. It was assumed that the external dependency of Brazilian society provides particularity to the development of capitalism and to the institutionalization of Public Health in Brazil. The main objective of the study was to analyse Public Health as part of the state, i.e. as one of the means to establish an imposed political order and legitimate power. Four phases were analysed between 1889 to 1978 corresponding to political ruptures of the government and was focused on the state of São Paulo. The data showed that although Brazil became independent from Portugal in 1822 , Portuguese influence remained strong for a long period of time. At that phase, health activities as other social activities were private issues, being carried out by philantropic or religious associations. Upon the development of capitalism and under the impact of imperialism, Public Health increased its role and acquired its own area of state activity. Based on a bureaucratic form of organization, ideology was divulged, rules and health legislation were established, financial resources were allocated and different class or group interests, located inside or outside the state apparatus, were assured to coexist. Through that formal organization the relationship between health bureaucracy and clientele politics was guaranteed. Therefore, public resources were drained on behalf of private interest. It was demonstrated that alongside with it development, Public Health has consolidated itself as a state activity and has its action legitimated even when coercive measures are needed. 
I I QUESTÕES TÉ́RICAS $\ldots \ldots \ldots \ldots \ldots \ldots \ldots \ldots \ldots \ldots \ldots \ldots \ldots \ldots$

1. DO ESTADO $\ldots \ldots \ldots \ldots \ldots \ldots \ldots \ldots \ldots \ldots \ldots \ldots \ldots \ldots \ldots$

2. DO TRABALHADOR À COLETIVIDADE $\ldots \ldots \ldots \ldots \ldots .24$

3. DO ESTADO E DA REPRODUÇÃO DA FORÇADE-TRABALHO NO BRASIL: ALGUMAS NOTAS ........ 33

II I - QUESTÕES METODOLÓGICAS

IV - SAÚdE PÚBLICA: REPRODUCÃO OU LEGITIMACÃO? ....... 40

1. O CARÁter EVENTUAL DA SAÚde PÚBLICA: as COMISSÕES (ATÉ 1889) ................. 40

2. A FORÇA-DE-TRABALHO E A CONEXÃO INTERNACIONAL（1889-1930）

3. A INSTITUCIONALIZACÃO DA SAODE PÚBLI CA: A RACIONALIDADE TẼCNICA (19301945)

4. A CRIANÇA, O TRABALHADOR RURAL E A NECESSIDADE DO CONTROLE DA IRRACIONALIDADE (POLÍTICA) (1945-1964) ........... 118

5. O SONHO DOS SANITARISTAS E O RETORNO À RACIONALIDADE (1964-1978)

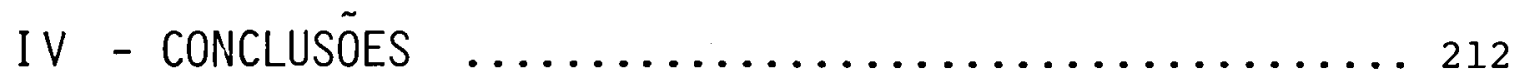
REFERÉNCIAS BIBLIOGRÁFICAS $\ldots \ldots \ldots \ldots \ldots \ldots 215$ 


\section{I NTRODUC, $\tilde{A} 0$}

Este trabalho resulta de um desafio de tentar res ponder algumas questões colocadas no decorrer do tempo.

Como desafio, é uma tentativa de superar o ponto de vista imediato da consciência comum, da Saúde püblica dos mosquitos, das vacinas, do leite; ou da consciência idealis ta, a Saúde Pública como agente de transformação da indigên cia, do trabalho com a comunidade, tentando desenvolver uma consciência mais crítica, que pudesse demonstrar o que a saú de Pública realmente é mas não aparenta, e o que aparenta ser, mas não é.

Não que estas colocações não sejam reais, elas o são, mostrando uma parte da realidade, bastante contínua e duradoura, necessāria, inclusive, para sua afirmação como ārea de atuação estatal. É por sua permanência e com uma par cela de sua essência que ela se afirma e se impõe como verda de, verdade essa que se relativiza nos momentos de crises, de conflitos sociais, resultantes de relações de classes anta gônicas e contraditórias.

São nos momentos de contradições, de conflitos, de insatisfações, de questões não respondidas e de decisões não adotadas que a Saúde pública reaparece, refluindo quando as mobilizações tornam-se menos intensas, como nota WAITZIKIN (1978).

A tentativa de buscar uma consciência critica tor na-se necessária no momento atual, no qual se redefine o pa 
pel da Saúde no Brasil e se mostram o seu caráter social, os interesses de diferentes frações de classes envolvidos, des mistificando seu carāter de neutralidade e demonstrando o que, em sua essência, ela sempre foi: um fenōmeno político. Necessária, também, porque como afirma VASQUEZ

"... tratando de satisfazer as aspirações "práticas" do ho mem comum, desenvolve-se, às vezes, a partir do poder, um trabalho destinado a deformar, castrar ou esvaziar a consciência política ..." ou "... a tendência alimentada a par tir do poder e destinada a destruir o mais leve despertar de uma clara consciência política, mantendo o homem comum e cor rente no mais absoluto apoliticismo. A despolitização cria, assim, um imenso vazio nas consciências, vazio que só pode ser útil à classe dominante, que recheia as consciências com atos, preconceitos, hābitos, lugares comuns e preocupações que, enfim, contribuem fortemente para manter a ordem social vigente ..."

São esses hábitos, lugares comuns que hoje estão presentes, o individual/coletivo, assistência sanitária/assis tência médica, público/privado, centralização/descentralização, municipalização/federalização, questões essas sempre colocadas na relação Estado/Sociedade e, principalmente, mo mentos de mudança dessa relação, inclusive, portanto, na ārea de saúde Pública.

KILBOURNE (1969:1) assinala que "... Public Health concerns the health of the public. Although the terms sometimes implies public responsability in the control of diseases and surveillance of health, in current usage it 
implies equally that the recipient of this

responsability and concern is the public (individuals collectively as they live together). Indeed benefits for the public are generally administered by public (or more precisely, by its elected or selected representatives)".

HOBSON (1965:IX) salienta que hā duas abordagens aos problemas de saúde e doença: "... the first is that concerned with the problem of health and sickness in the individual, and the second, the problem of health and disease in the community as whole." Ao assinalar a diferença entre Medicina Social e Saúde Pública, coloca que "... where as Public Health places the emphasis on the environment and deals with communities Social Medicine derives its inspiration from the field of clinical experience and dealts with individuals".

Em geral, aceita-se esta dicotomia, a divisão da Saúde, quanto ao seu objeto (indivíduofcoletivo), suas ações (médica/sanitária) e a responsabilidade (privada/pública), nu ma fragmentação de objetos, atos, profissionais e responsabi lidades, o que contribui para a alienação, para a divisão dos agentes sociais envolvidos e para reforçar essa visão dicotômica, cujas raizes encontram-se numa concepção de so ciedade harmônica e de um Estado, representante de interes ses gerais.

Neste sentido, este trabalho insere-se numa linha teórica de alguns estudos, que vêm sendo desenvolvidos no Brasil, sobre a relação Saúde e Sociedade, baseados principalmente, nos trabalhos pioneiros de DONNANGELO (1975, 1976). 
Tendo como objetivo geral analisar a Saúde pública como uma prática social, uma relação de classes sociais, além de sua instrumentalização técnica, pretende-se ainda demons trar que:

1 - a institucionalização da Saúde Pública faz parte da constituição de um Estado burguês;

2 - neste processo, dependendo das forças sociais, a Saúde Pública absorve āreas específicas e momentāneas, amplian do-se como órgão burocrático estatal;

3 - esta absorção corresponde à possibilidade de articulação entre interesses püblicos e privados.

Como hipótese norteadora, assume-se que, dadas as especificidades do desenvolvimento capitalista no Brasil, o papel da Saúde pública na reprodução da força-de-trabalho è secundário, sendo seu papel principal, como parte do aparelho estatal, impor um consenso sobre a questão da saúde, se lecionando problemas, organizando-se em torno de uma estrutú ra técnico-burocrata que lhe permite direcionar as formas de acesso, os tipos de serviços, os bens de consumo a serem dis tribuídos. Ao mesmo tempo considera-se que, como aparelho estatal, serve a interesses competitivos de classes e fra ções de classe, na posse de āreas institucionais. 


\section{DAS QUESTÕOS TEÓRICAS}

\section{DO ESTADO}

A relação Estado/sociedade (burguesa, civil) envol ve uma ampla discussão teórica e metodológica bastante com plexa e não resolvida. Recuperar essa discussão envolveria a elaboração de um trabalho teórico de maior profundidade, quando a opção foi analisar uma faceta delimitada daquela re lação, baseando-se em alguns de seus aspectos e que têm sido postos por alguns investigadores na relação saúde e Socieda de.

Neste sentido, colocam-se aqui alguns pressupostos teóricos que se mostraram fundamentais para anālise e com preensão do objeto de estudo, e que estão presentes na anāli se marxista ou não sobre a questão do Estado.

Um destes pressupostos consiste na constituição do Estado, tendo como base as condições materiais da sociedade, ou seja, um Estado emerge das relações sociais de produção que determinam suas formas, conforme assinalado por MARX (1971a:28).

"... as relações jurídicas assim como as formas do Estado não podem ser compreendidas por si mesmas, nem pela dita evolução geral do espírito humano, inserindo-se pelo contrário nas condições mate riais de existência ... na produção social da existência, os homens estabelecem relações determi 
nadas necessárias, independentes de sua vontade, relações de produção que correspondem a um determi nado grau de desenvolvimento das forças produtivas materiais. o conjunto destas relações constitui a estrutura econômica da sociedade, a base concreta sobre a qual se eleva uma superestrutura jurídica e política e à qual correspondem determinadas for mas de consciência social."

Um segundo pressuposto é que, sendo inerente às rẹ lações sociais de produção, o Estado não representa os inte resses gerais das classes sociais mas é a expressão política de uma classe economicamente dominante, conforme ENGELS (1964:137).

"Como o Estado nasceu da necessidade de conter an tagonismos das classes, e como, ao mesmo tempo, nasceu em meio ao conflito delas, é, por regra ge ral, o Estado da classe mais poderosa, da classe economicamente dominante, classe que, por intermé dio dele, se converte também em classe politicamen te dominante e adquire novos meios para repressão e exploração da classe oprimida."

Contudo, a classe economicamente dominante repre senta apenas os interesses de uma fração do capital, como as sinala ainda MARX (1979:29, 30), em oposição, mas não em contradição,com os interesses de outras frações, assumindo uma forma de governo (a monarquia absoluta).

"La que dominó bajo Luis Felipe no fue la burguesia francesa, sino una fracción della ... la llamada 
aristrocracia financeira. Ella ocupaba el trono, dictava leyes en la Camaras y adjudicaba los cargos públicos desde los ministerios hasta los estancos... el incremento de la deuda pública interes saba directamente a la fracción burguesa que gobernava y legislava através de las Camaras. El déficit público era precisamente el verdadeiro objeto de sus especulaciones y la fuente principal de su enriquecimento ..."

Nessa citação, Marx mostra, também, a vinculação da fração dominante com o aparelho estatal através das díví das públicas, assim como, pela administração e legislação.

A necessidade de acomodar esses interesses diferen tes leva à modificação da forma de governo.

"A monarquia burguesa de Luis Felipe só pode suce der uma república burguesa, ou seja, enquanto um setor limitado governou em nome do rei, toda bu guesia governará agora em nome do povo ... um po der que, de maneira geral, só era possível sob a forma de regime parlamentar, pois apenas sob essa forma podiam os dois grandes setores da burguesia francesa unir-se e, assim, pôr na ordem o domínio de sua classe, em vez do regime de uma facção prí vilegiada dessa classe..." (MARX, 1977:25, 46).

No entanto, o Estado não pode ser visto em sua na tureza, como Estado do Capital, de uma classe mas deve apare cer como expressão de uma vontade coletiva, representante de todas as classes, como algo separado das relações sociais de produção e acima das classes, ou na sua aparência. 
Tanto ENGELS (1964) como MARX (1977) mostram que há períodos em que as lutas de classes se equilibram de tal modo que o poder estatal adquire certa independência momentâ nea em face às classes; que as crises econômicas externas e os conflitos internos parecem esgotar as classes envolvidas e nenhuma delas é capaz de deter o poder político, submetendo-se a ser representado militarmente.

Como o Estado passa a ser uma abstração, o repre sentante dos interesses gerais?

ALVES (1987:28) nota que "... O Estado não se re duz às formas de sua objetivação, através de suas institui ções pelas quais se destaca concretamente na vida cotidiana e do ordenamento jurídico, que regula sua manifestação racio nal-formal e burocrática ..."

No mundo cotidiano, o Estado se apresenta com seus atos, decisões, ações, instituições ou seja um sistema. de normas ou regras legalmente sancionadas, sendo que a estrutu ra que o determina permanece oculta. A prática reiterativa e imediata, reproduzindo regularidades e reforçada pela con tinuidade das administrações, impregna a consciência dos in divíduos, transformando-a em uma única forma de realidade existente, natural e independente dos homens. Realidade es sa necessāria, uma vez que não pode ser pura abstração, mas também, não pode dela prescindir para o exercício da domina ção.

Essa abstração decorre do fetichismo da mercadoria (1)

(1) O capitalismo caracteriza-se por ser uma sociedade de proprietários de mercadorias, de coisas (res em latim, dai reificação) a serem tro cadas, vendidas. As relações entre proprietários (dos meios de pró dução e de força-de-trabalho), indivíduos juridicamente livres que estabelecem um contrato, aparecem como relações entre vontades independentes, entre sujeitos juridicamente iguais. 0 fetichismo expres sa essa independência, algo que existe por si só, com vontade própría 
concebendo-se o Estado como algo independente, separado das relações sociais de produção. Assim como não se pode deduzir mercadoria de dinheiro, não se pode conceber o Estado a partir da circulação de mercadorias.

"O fetichismo da mercadoria faz com que o Estado apareça como algo acima das classes. A generalizą ção da mercadoria não pode existir sem que exista - como pré-condição - o desenvolvimento do capital. o capital é uma relação social. A acumulação do capital não exclui o jogo das classes sociais... é - elemento desfetichizador das relações de prodụ ção... O fetichismo se faz acompanhar pelo seu contrário: o desfetichismo. o Estado é a resposta a essa desfetichização. Garantindo o respeito pe las regras de troca, ele garante a possibilidade da exploração e de sua perenidade." (MATHIAs \& SALAMA, 1983:25).

E ainda SAluma $(1980: 127)$ que afirma "... O Estado deve ser deduzido do capital. A ação do Estado se exerce primeiro e fundamentalmente em relação ao capital em geral e, em seguida, em relação aos capitais múltiplos." Neste sentí do, o Estado é o "capitalista coletivo ideal" como afirma ENGELS (1975:93).

"E o Estado moderno, por seu turno, é apenas a or ganização que a sociedade burguesa a si prōpria deu para manter em pé as condições exteriores do modo de produção capitalista, defendendo-se das usurpações tanto dos operários como dos capitalis 
tas individuais. O Estado moderno, seja qual for

a sua forma, é uma māquina essencialmente capitalis ta individual, é o Estado dos capitalistas, o capitalista nacional ideal ...".

Estado este "... que garante a liberdade e a igual dade formais, necessárias à produção do capital ... a especi ficidade do Estado é aparecer garantindo a troca de equivalentes para permitir, na realidade, a troca de desiguais... um Estado é uma abstração que se efetiva na realidade das lu tas de classes sob a forma de regime político ..." (SALAMA, $1980: 128,135)$ conforme esquema abaixo:

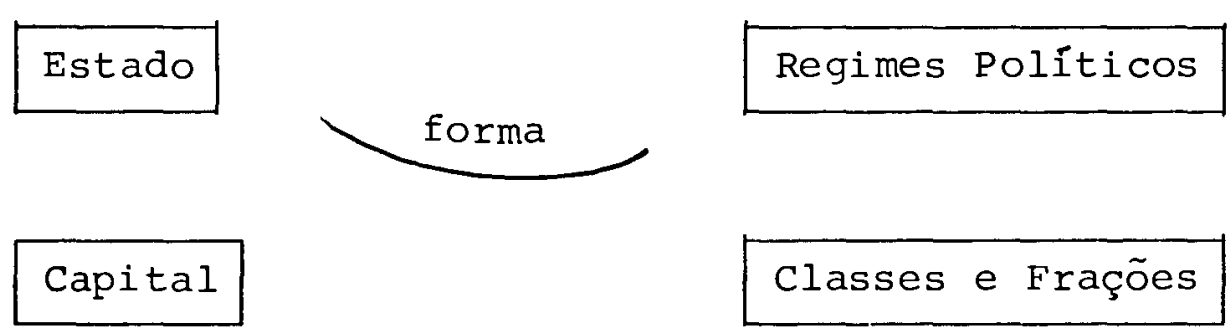

FONTE: MATHIAS \& SALAMA (1983:175).

Portanto, assim como as relações econōmicas se ex pressam como relações de troca, de circulação de mercadorias, ocultando as relações sociais de produção, as relações políticas expressam-se como relações entre indivíduos juridica mente livres e iguais perante um Estado neutro, um Estado de bem estar social, acima das classes.

Como exerce o poder político? Poder este definido como "... capacidade de uma classe social de realizar seus interesses objetivos específicos em oposição a outras clas ses ..." (POULANTzAs, 1971:111). Esta dominação política é exercida via aparelhos de Estado, através de mecanismos coe $\underline{\underline{r}}$ 
citivos diversos, dos quais a utilização da força, da violên cia física, é fundamental.

ENGELS (1964:136) mostra que a divisão da sociedade em classes cria a necessidade de "... instituição de uma força pública, que jā não se identifica com o povo em armas ... impossibilita qualquer organização armada e espontànea da população... Esta força pública existe em todo Estạ do, é formada não só de homens armados como ainda, de acessó rios materiais, os cárceres e as instituições coercitivas de todos os gêneros..." .

WEBER (1964:99) considera o monopólio do uso da vio lência pelo Estado como legítimo. Para o autor, hã três justificativas interiores e,portanto, legitimações básicas pạ ra este domínio:

1 - "A autoridade de ontem eterno, isto é, dos mores santifi cados pelo reconhecimento inimaginalvemente antigo e de orientação habitual para o conformismo. E o domínio do "tradicional" ...

2 - "Há a autoridade do dom da graça (carisma) extraordinário e pessoal, a dedicação absolutamente pessoal e a confian ça pessoal na revelação, heroísmo ou outras qualidades de liderança individual. E o domínio "carismático" ...

3 - "Há o domínio em virtude da "legalidade", em virtude da fé na validade do estatuto legal e da "competência" fun cional, baseadas em regras racionalmente criadas. Neste caso, espera-se a obediência no cumprimento das obriga ções estatutárias ..." 
E este domínio, que constitui a essência da admi nistração burocrātica, um exercício da dominação, baseado no saber racional que, acrescido a uma prática de conhecimento especial dos fatos e de documentos,possibilitam-na a deter - chamado "segredo profissional".

Cabe ressaltar que, para o autor, poder é a " ... possibilidade de que um homem ou um grupo de homens realize sua vontade prōpria numa ação comunitária até mesmo contra a resistência de outros que participem da ação ...".

o uso da força física, porém, como ressalta BoBBIo (1987) não é condição suficiente para definir o poder políti co mas sim sua exclusividade. Mesmo a exclusividade não é elemento suficiente para sua efetividade (o poder, fundado apenas na força, não pode durar) ou para sua legitimidade (po de ser efetivo mas não é legítimo).

Consequentemente, há necessidade de outros mecanis mos coercitivos como a persuasão, a busca de um consenso,que dê legitimidade a esse poder.

A distinção entre os dois tipos de coerção remonta à Idade Média, resultante da relação Estado/Igreja "... na contraposição à potestade espiritual e às suas pretensões, os defensores e detentores da potestade temporal tendem a atri buir ao Estado o direito e o poder exclusivo de exercer a força física sobre um determinado território e com respeito aos seus habitantes, deixando à Igreja o direito e o poder de ensinar a verdadeira religião e os preceitos da moral, de salvaguardar a doutrina dos erros, de dirigir as consciên cias para alcance dos bens espirituais, acima de tudo a sal 
vação da alma ..." (BOBBIO, 1987:80).

Como nota BOBBIO et alii (1986:579) o termo hege monia, derivada do grego egemonia (direção suprema de chefes militares, consequentemente, tendo um carāter de força) tem sido utilizada na literatura política para indicar " ... a supremacia de um Estado-Nação ou de uma comunidade político -territorial dentro de um sistema. A potência hegemônica exerce sobre as demais preeminência não só militar, como tam bém, frequentemente econômica e cultural inspirando-lhes e condicionando-lhes as opções, tanto por força de seu elevado prestígio, como em virtude de seu elevado potencial de intimidação e coerção ..." .

MARX \& ENGELS (1983:72) assinalam esse aspecto ima terial: "... a classe que é a força material dominante da sọ ciedade é, ao mesmo tempo, sua força espiritual dominante. A classe, que tem a sua disposição os meios de produção mate rial, dispõe, ao mesmo tempo, dos meios de produção espiri tual, o que faz com que a ela sejam submetidas ao mesmo tem po e em média, as idéias daqueles aos quais faltam os meios de produção espiritual ...".

O conceito de hegemonia, contudo, ganha maior ex pressão com as análises de Gramsci que parte dos estudos de Lenin sobre a questão da ditadura do proletariado, na qual caberia a este um papel de coesão de direção e organização como:

"... única classe capaz de unir todos os trabalha dores e explorados na luta contra a burguesia ... necessita do poder de Estado, de uma organização 
da violência, tanto para reprimir a resistēncia dos exploradores como para dirigir a imensa massa de população, o campesinato, a pequena burguesia, os semi-proletários, na obra da organização da economia socialista ... de dirigir e organizar uma no va ordem, de ser o educador, dirigente, o chefe de todos os trabalhadores ..." (LENIN, 1978:238, 239).

Em Gramsci, a hegemonia denota uma di reção inteleç tual e moral ou seja, um processo no qual parte da classe do minante, na sociedade civil, exerce uma liderança intelec tual e moral sobre as outras classes, impondo-lhes sua visão de mundo:

"... o desenvolvimento político do conceito de he gemonia representa um grande progresso filosófico, além de político-prático porque implica e supõe uma unidade intelectual e uma idéia em conformidade com uma concepção real que superou o senso coㅇ mum ..." (GRAMSCI, 1978a:30).

A hegemonia, na concepção de GRAMSCI (1978b:224), distingue-se do aparelho coercitivo:

"... conceito de Estado, que comumente é entendido como Sociedade Política (ou ditadura ou aparelho coercitivo para moldar a massa popular ao tipo de produção e à economia de dado momentol e não como um equilíbrio da sociedade Política com a Sociedade Civil (ou hegemonia de um grupo social sobre a sociedade nacional inteira exercida através de or ganizações particulares como Igreja, os sindicatos, 
as escolas), e justamente na sociedade civil em particular operam os intelectuais ..."

mas não prescinde dele para se impor:

"Os intelectuais são os "comissários" do grupo dọ minante para o exercício das funções subalternas da hegemo nia social e do governo político, isto é, 1) do consenso "espontâneo" dado pelas grandes massas da população à orien tação impressa pelo grupo fundamental dominante à vida so cial, consenso que nasce "historicamente" do prestígio (e portanto, da confiança) que o grupo dominante obtém por sua posição e sua função no mundo da produção; 2) do aparelho de coerção estatal que assegura legalmente a disciplina dos grupos que "não consentem nem ativa nem passivamente", mas que é constituído para toda a sociedade, na previsão dos mo mentos de crise no comando e na direção, nos quais fracassa o consenso espontâneo ..." (GRAMSCI, 1978c:11).

A necessidade de intelectuais, ligados às classes sociais para o exercício do poder político, é assinalada por diversos autores:

"com a divisão do trabalho ... expressa-se também no seio da classe dominante como divisão do trabạ lho espiritual e material, de tal modo que, no in terior desta classe, uma parte aparece como os pen sadores dessa classe" (MARX \& ENGELS, 1983:72, 73). GRAMSCI (1978c:3) assinala a presença desta catego ria nas diferentes formações sociais:

"cada grupo social, nascendo no terreno originário de uma função especial no mundo da produção econô- 
mica, cria para si, ao mesmo tempo, de um modo orgâa nico, uma ou mais camadas de intelectuais que the dão homogeneidade e consciência de sua prōpria fun ção e não apenas no campo econōmico; mas também no social e politico ...".

Nota, também, que cada grupo social encontrou cate gorias de intelectuais preexistentes, surgidas e desenvolvi das em estruturas econōmicas anteriores. Essas categorias apareciam "... aliás como representantes de uma continuidade histórica que não fora interrompida nem mesmo pelas mais com plicadas e radicais modificações das formas sociais e políti cas". Dentre estes e como uma categoria depois dos eclesiás ticos "... a categoria dos médicos, em sentido lato, isto é, de todos aqueles que "lutam" ou parecem lutar contra a morte e as doenças ...", lembrando a conexão entre religião e medi cina. Chama a atenção para o fato de que, dada a continuida de histórica e sua qualificação, "... eles consideram a si mesmos como autónomos e independentes do grupo social domí nante ..." (GRAMSCI, 1978c:5, 6) fato este que lhes permite ainda mais recorçar sua imagem como elementos neutros, autônomos com características próprias.

Como o próprio autor assinala, a indução a essa falsa concepção é dado pelo "... critério de distinção no que é intrínseco às atividades intelectuais e não ao conjun to 'do sistema de relações nas quais essas atividades le, por tanto, os grupos que as personificam) se encontram, no con junto geral das relações sociais" (GRAMSCI, 1978c:6, 7). 
das frações médias da burguesia entre as camadas de intelec tuais, que fazem parte do aparelho estatal. GRAMSCI (1978c: 10) nota, inclusive, que o desenvolvimento desigual cria in telectuais que se inserem diferentemente na divisão do trạ balho:

"... trata-se das mesmas camadas que, muito fre quentemente, especializaram-se em "poupança", isto é, a pequena e média burguesia fundiāria e alguns estratos de pequena e média burguesia das cidades ... assim, na Itália, a burguesia rural produz no tadamente funcionários estatais e profissionais li berais, ao passo que a burguesia urbana produz téc nicos para indústria, por isso a Itália setentrio nal produz notadamente técnicos e a Itália meridio nal notadamente funcionários e profissionais ..."

chamando a atenção para sua função político-social de media ção:

"... Este tipo de intelectual põe em contato a mas sa componesa com a administração estatal ou local. ... por isso possui uma grande função político-social jā que a mediação profissional dificilmente se separa da mediação política. Além disso, no campo, o intelectual (padre, advogado, professor, médico, etc...) possui um padrão de vida médio su perior ou pelo menos diverso daquele do médio cam ponês e representa, por isso, para esse camponês um modelo social na aspiração de sair de sua condi ção e de melhorā-la ..." (GRAMSCI, 1978c: 13). 
MARX $(1977: 59,116,120)$, ao analisar o desenvolvi mento capitalista na França e com esse a destruição das ba ses econômicas do campesinato, mostra como ele, é utilizado como uma classe de apoio ao regime napoleônico. Assinalando que os pequenos camponeses por sua condição de classe, por sua natureza de classe.

"... que tem que ser representados. Seu represen tante tem, ao mesmo tempo que aparecer como seu se nhor como autoridade sobre eles, como um poder go vernamental ilimitado que os protege das demais classes e que do alto lhes manda sol e chuva .... A pequena propriedade forma uma base adequada à burguesia toda poderosa e inumerável ... Finalmen te, produz um excesso de desempregados para os quais não há lugar nem no campo nem nas cidades, e que tentam, portanto, obter postos governamen tais como ura espécie de esmola respeitável, provo cando a criação de postos do governo ... aqui, en contra postos para sua população excedente e com pensa sob forma de vencimentos o que não pode em bolsar sob forma de lucros, rendas, juros e honorā rios ... Por outro lado, seus interesses polítí cos forçaram-na a aumentar, diariamente, medidas de repressão e, portanto, os recursos e o pessoal de poder estatal ...".

Assim, sob diferentes regimes políticos, frações médias tendem a preservar seus prōprios interesses, em articulação com aqueles da classe que representam, na posse do 
aparelho estatal "... os partidos que disputam o poder enca ram a posse desta imensa estrutura de Estado como principal espólio do vencedor ..." (MARX, 1977:114).

WEBER (1985:20, 21) nota, também, esta relação as sinalando que no sistema parlamentar baseado na representacão de grupos profissionais corporativos para a burocracia "... aumentaria a oportunidade e tentação de aproveitar-se dos in teresses econômicos divergentes e de expandir o sistema de ajuda mútua de concessão de cargos e contratos, a fim de pre servar o seu próprio poder ... Em estados não parlamentaris tas (como na Alemanha Imperial), os partidos não controlam a concessão de cargos máximos, mas os partidos mais influen tes podem geralmente pressionar a burocracia dominante no sen tido de conceder cargos políticos a seus protegidos, ao lado dos candidatos recomendados por ligações com funcionários efé tivos ...".

Verifica-se, portanto, a complexidade da relação Estado/classes sociais. As oposições existentes entre as di ferentes frações da burguesia, somam-se às contradições de outras classes; oposições e contradições presentes no apare lho estatal, gerando diferentes alianças e/ou conflitos.

E dentro deste contexto de diferentes interesses das frações de classes, que se deve analisar a questão buro crātica, uma vez que "... a relação entre intelectuais e o mundo da produção não é imediata, como o caso dos grupos sô ciais fundamentais, mas é "mediatizada", em diversos graus por todo um contexto social, pelo conjunto das superestrutú ras do qual os intelectuais são precisamente os funcionários" (GRAMSCI, 1978c:10). 
Como se processa a relação Estado-burocracia-clas-

ses?

Com o desenvolvimento das forças produtivas e "a divisão do trabalho na sociedade burguesa, criando novos gru pos de interesses e, por conseguinte, novo material de administração do Estado" (MARX, 1977:114) e com a necessidade de consolidação da dominação, amplia-se o aparelho burocrático:

"a primeira Revolução Francesa, em sua tarefa de quebrar todos os poderes independentes, locais, ter ritoriais, urbanos e provinciais - a fim de estabe lecer a unificação civil da nação, tinha forçosa mente que desenvolver o que a monarquia absoluta começara: a centralização mas ao mesmo tempo, o âm bito, os atributos e os agentes de poder governamental ... Finalmente, em sua luta contra revolu ção, a república parlamentar, viu-se forçada a con solidar, juntamente com as medidas repressivas, os recursos e a centralização governamental ..." (MARX, $1977: 114)$.

o crescimento da burocracia com o desenvolvimento capitalista também, é assinalado por WEBER (1985:17):

"o progresso em direção ao Estado burocrático que julga e administra segundo o direito e os precei tos racionalmente estabelecidos, tem, hoje em dia, estreitas relações com o desenvolvimento do capitą lismo moderno ..."

A incorporação de diferentes frações de classes no 
aparelho estatal burocrático introduz interesses conflitartes e mutantes. O desenvolvimento das forças produtivas, o avan ço científico-tecnológico e divisão do trabalho, assim como a apropriação destes conhecimentos modificam a importância dos diferentes intelectuais e, portanto, sua posição na es trutura de dominação. Ou seja, seu papel no aparelho esta tal está condicionado à importância de seu saber para conti nuidade e reprodução da sociedade.

Como nota Poulantzas $(1980: 64,69)$ "a apropriação da ciência pelo capital se faz certamente na fábrica mas igual mente pelo Estado ... Não se trata de uma simples instrumen talização da ciência ou de sua manipulação ao serviço do cá pital. O estado capitalista arregimenta a produção da ciên cia que se torna uma ciência de Estado, imbricada, em sua textura intrínseca nos mecanismos de poder ...". Ressalta, ainda, o papel fundamental dos intelectuais afirmando: "... baseada num campo que implica a especialização característica de suas funções e do trabalho intelectual, a burguesia é a primeira classe da história que tem a necessidade para se firmar como classe dominante, de um corpo de intelectuais or gânicos. Estes, formalmente distintos dela, embora arregi mentados pelo Estado, não têm um papel de simples instrumento (como o caso dos padres no feudalismo) mas um papel de organização da hegemonia ...".

Necessários porque portadores de uma racionalidą de, que tem como pressuposto que as técnicas fundamentais na ciência podem resolver os conflitos de classes e evitar os antagonismos, racionalidade essa, portanto, que tem a função 
de obscurecer estes conflitos.

"A relação poder-saber se traduz por tēcnicas par ticulares de exercício de poder, por dispositivos precisos, inscritos na trama do Estado, de distanciamento permanente das massas populares dos cen tros de decisão: por uma série de rituais de for mas de discurso, de modos estruturais de tematizą ção, de formulação, de tratamento dos problemas pe los aparelhos de Estado de maneira tal (monopoliza ção do saber) que as massas populares (nesse sentí do trabalho manual) ficam de fato à parte disso.. ." (Poulantzas, 1980:67).

A posse desses conhecimentos tēcnico-científicos dá aos intelectuais-burocratas à legitimidade necessāria para estabelecer um consenso.

Esta legitimidade possibilita a capacidade de oㅁ tenção e controle de recursos ou seja, contratar força-detra balho, fornecer serviços, adquirir e distribuir bens e ele var sua capacidade operativa, necessārios a sua existência e reprodução.

Contudo, o controle desses recursos deve articular -se com os interesses externos e nessa articulação, a racionalidade técnica, o domínio da razão, subordina-se à "irracio nalidade" política, o domínio da paixão.

"Executivo, parlamento, exército, magistratura, di ferentes ministérios, aparelhos regionais, munici pais ou centrais, aparelhos ideológicos, eles mes 
mos divididos em circuitos, redes e trincheiras di ferentes, representam com frequência, conforme as diversas formações sociais, interesses absolutamen te divergentes de cada um ou de alguns componentes do bloco do poder ... Muito mais que com um corpo de funcionários e de pessoal de estado unitário e cimentado em torno de uma vontade política unívoca, lida-se com feudos, clãs, diferentes facções, em soma com uma multidão de micropolíticos diversificados ..." (POULANTZAS, 1980:153).

Dividida, fragmentada, mas ao mesmo tempo, homogeneizada e unificada em torno do Estado-Nação, a burocracia tem um importante papel, como demonstram CLOWARD \& PIVEN (1974), na diminuição da influência das classes populares na esfera pública.

Influência esta a que o Estado se contrapõe e, nes te sentido, a utilização de mecanismos coercitivos não deve ser vista apenas em seu aspecto negativo, de repressão, de contenção e exclusão mas em seu aspecto positivo de constru tor, de organizador das relações sociais de produção. Na bus ca da hegemonị, o Estado promove uma série de medidas positivas para a classe trabalhadora, imposta pelas lutas de classe, o que não exclui o aumento da exploração.

E dentro dessas considerações anteriores, que deve ser vista a questão da reprodução das relações sociais. E o papel do Estado nesta reprodução, inclusive da força-de-trabalho que extrapola a simples qualificação desta força mas envolve toda uma sērie de medidas, em relação ao consumo co- 
letivo, entre as quais a saúde.

E se no processo de desenvolvimento capitalista, há uma priorização de determinadas frações de capital, ocorre, também o não favorecimento de outras. Este fenômeno tem con seqthências fundamentais nas diferentes condições da classe trabalhadora e na sua possibilidade de obter uma melhor qua lidade de vida e de saúde.

\section{DO TRABALHADOR A COLETIVIDADE}

A Organização Mundial da Saúde - oMs - define saú de como "... o completo bem-estar, físico, mental e social ...", englobando nesta definição vários aspectos, afirmando que saúde é um bem, uma qualidade inerente ao homem.

Esta qualidade assume em determinado momento histó rico um valor econômico e fundamental para sobrevivência do homem, e associa-se à sua capacidade de pôr em movimento um conjunto de energias de uma determinada maneira, num determi nado modo de produção, donde a posse desta qualidade - ter saúde - deve ser redimensionada.

E neste redimensionamento que a Saúde Pública, coㅇ mo uma prática social, relações de classes sociais, "o cole tivo", origina-se nos paises centrais, visando a recompor as energias consumidas no processo produtivo, recomposição esta que permite a reprodução social e o desaparecimento dos agen tes sociais. Neste sentido, a Saúde Pública, como prática social, resulta da contradição fundamental entre capital/tra 
balho, da divisão do "coletivo" em classes antagônicas, cons tituindo-se elemento importante na reprodução capitalista, sejam em nivel infra ou supra-estrutural.

Esta constatação generalizadora pouco significa sem que se recupere como a saúde, medida como capacidade de trabalho, cria valor excedente.

E atravēs de relações sociais, do processo e da divisão social do trabalho, que se constrói o objeto da saú de Pública, encoberto, ideologicamente, pelas inúmeras desig nações como: coletividade, indigência, carência, ou seja, um grupo de individuos que, aparentemente, não possuem ou aos quais falta algum atributo essencial necessārio àquilo que a sociedade considera à integração social. Se este atributo essencial, numa sociedade capitalista, é o trabalho e através dele os homens participam do processo de produção e distrí buição e têm acesso às mercadorias, pode-se afirmar, a prin cípio, que esta massa de individuos, parte do coletivo, tem como característica o não-trabalho, impedindo-a de ter acesso aos bens de consumo e serviços necessários à sua sobrevivência ou de ter saúde, em grau suficiente para integrar-se no processo produtivo e/ou distributivo. Como se adquire es ta incapacidade de obtenção dos meios de subsistência na so ciedade capitalista?

Na análise marxista do desenvolvimento capitalista, verifica-se a transformação do dinheiro em capital comercial e deste em capital produtivo; este mesmo movimento do capi tal é acompanhado pela transformação do trabalho. No início, - capital comercial compra a força-de-trabalho que, neste 
momento, possui ainda os meios de produção, mas jā não de tém a matéria prima. Portanto, o capital ainda não dispõe de uma mão-de-obra livre, estando sujeito não só às formas de produção pré-capitalistas como à sua população, caracterí zada pela alta natalidade e mortalidade e por um processo migratōrio incipiente, fatores limitantes, não só para a re produção da mão-de-obra como para sua circulação no mercado.

Ambos, capital comercial e trabalho artesanal e do méstico, passam a constituir entraves ao desenvolvimento das forças produtivas e é com a transformação destes em capital produtivo que se verifica a concentração dos meios de produ ção e de mão-de-obra, previamente liberada para circulação no mercado.

Esta concentração de indivíduos, desprovidos dos meios de produção, absorvidos ou não pela produção capitalís ta, não se faz acompanhar de uma estrutura urbana adequada, gerando precárias condições de habitação e de subsistência e, consequentemente, favorecendo o aparecimento e a rápida trans missão de doenças e uma maior mortalidade, ameaçando a pró pria viabilidade capitalista, que necessita de um afluxo cons tante da força-de-trabalho. Esta situação agrava-se, ainda mais, dada a intensidade de exploração, que reduz não só a expectativa de vida da força-de-trabalho como sua própria reprodução biológica, pela incorporação maciça de mulheres e crianças.

MARX (1971b) e, posteriormente, ROSEN (1980) citam inúmeros trabalhos desenvolvidos por médicos, assinalando as consequências do processo produtivo na saúde dos trabalhạ 
dores. KAY (apud Rosen:92), em 1832, notava que mais da me tade da população de Manchester eram "... tão carentes ou tão aviltados que precisavam da assistência da caridade pú blica para trazer sua prole ao mundo". THACKRAY (apud Rosen: 93), num tratado pioneiro de medicina ocupacional, em 1831, ressaltava o estado de "... milhares de crianças, muitas en tre seis e sete anos de idade, arrancadas de seus leitos ain da de madrugada para correr para as fábricas e lá serem man tidas, com um único intervalo de quarenta minutos, até horas avançadas da noite". GASKELL (apud Rosen:94), em 1833, acha va que as condições sobre as quais os operārios viviam e tra balhavam afetavam sua saúde; "... a vida, concluiu ele, ape sar de não necessariamente encurtada pela ocupação manufatureira sofre a queda de um aspecto que é de extrema importân cia e que tem o poder de tornā-la deliciosa - a posse da saú de. E, daqueles que trabalham na fäbrica, pode ser dito que vivem numa vida próxima à morte."

Observa-se, pelas descrições, que ao capital inte ressava um afluxo, uma quantidade de força-de-trabalho, não importando a sua qualidade e é aqui que residem os limites da Saúde Pública que se pretende reger por uma lógica qualitativa mas deve atender a uma lógica quantitativa, uma quantidade mínima para produzir.

Nesta lógica, deve atender, tambēm, aos interesses das outras classes a fim de que esta quantidade mínima não possibilite a rāpida disseminação e transmissão de doenças, que não obedecem as fronteiras classistas e cujo controle é desconhecido. E é este aspecto que, ainda, constitui a tare 
fa fundamental da Saúde pública, o controle de determinados tipos de doenças, passíveis de serem transmitidas às classes dominantes e não todas ou quaisquer doenças, que em nada afe tam as outras classes e se as afetam, não trazem consequên cias tão graves como para a classe trabalhadora. Proteção às classes capitalistas e disponibilidade de classes trabalhado ras, as classes sociais, eis a ārea de atuação da saūde pū blica.

A disponibilidade de mão-de-obra para produção é recolocada, constantemente, no desenvolvimento do capitalis mo. MARX (1971b:132) assinala que, ao produzir a acumulação do capital, a classe trabalhadora "... produz em proporções crescentes os meios que fazem dela uma população supérflua ou um exército industrial de reserva, que excede às necessidades médias da expansão do capital. Esta é a lei da popula ção peculiar ao modo de produção capitalista".

Com o desenvolvimento das forças produtivas, o prọ cesso de acumulação sofre mudanças periódicas que interferem na totalidade do capital ou mudanças simultâneas e em diferen tes ramos de produção. Este movimento altera a composição orgānica do capital, expandindo ou contraindo sua parte va riável, que está sujeita a oscilações; ou o capital variável põe em movimento maior quantidade de força-de-trabalho sem recrutar novos trabalhadores (trabalho intensivo e extensivo) ou mobiliza quantidade de forças-de-trabalho inferiores (menos qualificadas) ou mão-de-obra incipiente (mulheres, jo vens, crianças), expulsando as de nível superior (mais quali ficadas) ou mão-de-obra madura (homens e adultos) criando uma 
população ociosa.

"O trabalho excessivo de parte da classe trabalhadora empregada engrossa as fileiras do exército de reserva, enquanto que a forte pressão que este exerce sobre aquela, através da concorrência, com pete ao trabalho excessivo e às exigências do capi tal. A condenação de uma parte da classe trabalhạ dora à ociosidade forçada, em virtude do trabalho. excessivo de outra parte, torna-se fonte de enriquecimento individual dos capitalistas e acelera ao mesmo tempo a produção de um exército indus trial de reserva numa escala correspondente a pro gresso da acumulação de capital".

As relações sociais não se limitam à esfera da pro dução, em nível infraestrutural. De um lado, a realização da mais-valia só se concretiza com a distribuição e circula ção das mercadorias e posterior consumo e de outro, para que a produção capitalista se realize, ela necessita de mecanismos externos, em nível supraestrutural.

Como coloca OFFE (1984:18, 20) "... é necessário dẹ finir, através de uma regulamentação política quem pode e quem não pode tornar-se trabalhador assalariado ... Daí,por um lado, a tendência de considerar delituosos e reprimir mo dos de subsistência que constituíam uma alternativa de traba lho assalariado (da proibição da mendicância aos atos de re pressão do tipo da lei anti-socialista) e, por outro, a transmissão de normas e valores, organizada pelo Estado cu ja ob servância assegura a passagem para a relação de trabą 
tho assalariado ...".

E necessário que a classe operária "... por educa ção, tradição e uso, reconheça as exigências daquele modo de produção como sendo leis da natureza evidentes" (MARX, 1971b: $854)$.

Consequlentemente, na estrutura social, além dos trabalhadores diretamente ligados à produção da mais-valia, constatam-se outros tipos de trabalhadores. PEREIRA (1977: 22), referindo-se "... aos portadores individuais da mercado ria força-de-trabalho efetiva ou ativa, assinala as seguin tes categorias ...": 1) trabalhadores produtivos ou seja produtores (diretos) da mais-valia global; 2) trabalhadores improdutivos ou seja trabalhadores não produtores da maisvalia global, cabendo distinguir, entre eles, duas catego rias: a) os envolvidos "infra-estruturalmente no processo de realização da mais-valia produzida (comerciários, por exemplo) e b) os assalariados dos aparelhos repressivos e ideológicos do Estado que, contribuem como tais, para a pro dução e para a realização da mais-valia (e, portanto, para a acumulação do capital) através da produção e reprodução de condições não-naturais (supra-estruturais dominantes) necessārias à produção e à realização da mais-valia); 3) os portadores (assalariados) da função do capital".

Assinalada a existência de diferentes trabalhado res, assim como de um exército industrial de reserva, cabe ressaltar a preșença de uma superpopulação relativa, como ob serva MARX (1971b:743). "... Além das diferentes formas em que o trabalhador está desempregado ou parcialmente emprega- 
do, a superpopulação relativa assume três outras formas: flu u tuante, latente e estagnada...".

E flutuante quando os trabalhadores são atraídos ou repelidos "... em quantidade maior, de modo que no seu conjunto aumenta o número de empregados, embora em proporção decresce com o aumento da produção ..." (MARX, 1971b:744)cons tituem também a população flutuante meninos e rapazes que, ao atingirem a idade adulta, são despedidos, sendo absorvida ape nas uma pequena parcela. A forma latente é gerada pela pene tração do capitalismo na agricultura, quando diminui a procu ra absoluta da população trabalhadora rural e parte dela, em bora expulsa, não é absorvida na indústria, encontra-se na iminência de se transferir para a cidade; mas este fluxo só é possível dada a existência, no campo, de uma superpopulação supérflua sempre latente. A forma estagnada é composta de trabalhadores com ocupação totalmente irregular, trabalhadores à domicílio.

Assinala, ainda, a existência de uma outra forma que "... vegeta no inferno da indigência e do pauperismo.Pon do de lado os vagabundos, criminosos, prostitutas, o rebotalho do proletariado, esta camada social consiste em três ca tegorias: primeira, os aptos para o trabalho, cujo número au menta em épocas de crises; segunda, os órfãos e filhos de indigentes; terceira, os degradados, desmoralizados e incapazes de trabalhar (incapacidade à divisão do trabalho, os que ultrapassam a idade normal, os mutilados, enfermos e viū vos)..." (MARX, 1971b:746). 
Esta população supérflua mas necessāria não pode ser vista como resultante do processo de acumulação, mostran do sua outra face, a miséria. E, portanto, esta última deve aparecer como um atributo individual, encobrindo seu caráter social.

Com estas considerações, pode-se concluir que, no processo de desenvolvimento capitalista, sua acumulação gera o trabalho produtivo e improdutivo, assim como, o não-trabalho ou seja, cria uma massa de trabalhadores assalariados, ten do acesso, embora diferencial, aos bens e serviços que possi bilitam sua sobrevivência através de um salário regular, e outra massa de trabalhadores, embora necessária ao capital, não teria esta mesma situação: trabalho, salário e acesso aos bens e serviços.

Contudo, a relação trabalho assalariado/acesso a bens e serviços não é verdadeira e, mesmo o trabalho assalariado não permite aquele acesso de maneira satisfatória. Is to se verifica, na medida em que, como assinalam MARX (1971b); BRUNHOFF (1978) e OFFE (1984), ao capital interessa apenas remunerar o valor da força-de-trabalho diária e efetivamente dispendida e não sua paralisação por motivo de doença ou sua reprodução, o que representaria um custo a mais.

Nestas circunstâncias nem o trabalho nem o salärio constituem elementos suficientes para uma grande parcela da classe trabalhadora e suas famílias terem acesso aos bens e serviços que possibilitem conservar ou preservar ou mesmo manter a saúde. Mesmo porque este acesso atua num processo já de desgaste da força-de-trabalho não mais recuperável, num 
processo produtivo, cuja função, segundo MACCACARO (1973:79) é "... conservar, consumindo, consumir, conservando a força -de-trabalho". Exemplo disto, está nos corpos heterogêneos das diferentes classes; em alguns trabalhadores produtivos industriais que, submetidos duramente às condições ambien tais de trabalho, têm sua capacidade pulmonar reduzida deslo cando-se para o trabalho agrícola pouco qualificado "para re cuperar a saúde" perdida; contudo, já não contam mais com a mínima capacidade física mesmo para enfrentar a atividade agrícola, também poluidora e paga por produção (2). Desqualificado profissionalmente e, portanto, salarialmente, resta - lhe engrossar as fileiras dos trabalhadores pobres e indi gentes, objeto da Saúde pública, cabendo ao Estado, como ele mento, aparentemente, externo ao capital, criar mecanismos de gestão desta classe trabalhadora.

3. DO ESTADO E DA REPRODUÇ,̃̃O DA FORC,A-DE-TRABALHO NO BRASIL: ALGUMAS NOTAS

Embora conservando os elementos essenciais da pro dução e, portanto, de um Estado capitalista, a formação do Estado onde o capitalismo foi implantado do exterior, como o caso dos países colonizados e onde o próprio capitalismo im planta-se tardiamente e desenvolve com características específicas, coloca questões mais complexas.

(2) Comunicação pessoal de Dora Elisa Rodrigues Tolosa, da disciplina de Medicina do Trabalho. 
Uma das questões refere-se não à sua origem mas à institucionalização e consolidação de um Estado burguês, que se forma a partir da desintegração e crise de um Estado colo nial. Estado este, sob forma de monarquia com uma estrutura centralizadora e burocrática, necessária ao tipo de relações econômicas dominantes.

Se, nos países centrais, o Estado deriva do Capi tal, nos países colonizados, esta relação colônia-metrópole modifica esta relação, è de uma economia mundial constituída, que deriva o Estado, como assinalam MATHIAS \& SALAMA (1983).

Como demonstram estes autores, numa primeira etapa "... a conquista,' a pilhagem e a exploração necessitam de um poder no território ocupado" (MATHIAS \& SALAMA, 1983:41). Nu ma segunda etapa, a busca de uma autonomia e da detenção de uma parcela maior do excedente produzido dão origem aos movi mentos insurrecionais, que resultam numa autonomia política relativa e na implantação de um Estado-Nação, que se relacio na com o Estado-Nação dos paises centrais.

PEREIRA (1970) estabelece, em termos típico-ideais, três etapas de desenvolvimento capitalista e suas conexões entre centro e periferia e que estão resumida no quadro a se guir. 


\begin{tabular}{ll}
$\begin{array}{c}\text { Etapas do desenvol } \\
\text { vimento capitalis } \\
\text { ta }\end{array}$ & $\begin{array}{l}\text { Nexos entre sub } \\
\text { sistemas cen- } \\
\text { trais e perifé- } \\
\text { ricos }\end{array}$ \\
\hline CAPITALISMO & $\begin{array}{l}\text { Nexos comer- } \\
\text { ciais-legais } \\
\text { e monopolis- } \\
\text { tas }\end{array}$ \\
\hline
\end{tabular}

$\begin{array}{ll}\text { CAPITALISMO } & \text { Nexos comer- } \\ \text { LIBERAL OU } & \text { ciais puramen } \\ \text { CONCORRENCIAL } & \text { não-monomicosolis } \\ & \text { tas }\end{array}$

\begin{tabular}{ll}
\hline & \\
CAPITALISMO & $\begin{array}{l}\text { Nexos comer- } \\
\text { ciais mais in }\end{array}$ \\
MONOPOLISTA & vestimentos mo \\
OU NEOCAPI- & "poristas na \\
TALISMO & peria"
\end{tabular}

FONTE : PEREIRA (1970:43)
Natureza do Estado e das
ideologias

1. Nação-Estado em constituição no "centro"

2. Colonialismo na "periferia"

3. Estado racional-legal em consti tuição no "centro"

4. Liberalismo em constituição

1. Nação-Estado constituida no"cen tro"

2. Nação-Estado em constituição na "periferia"

3. Estado racional-1 egal constituí do no "centro"

4. Vigência da ideologia liberal

1. Colapso da Nação-Estado em cons tituição na "periferia" (neocolonialismo)

2. Ideologias pós-1iberais: neocapitalista e socialista

3. Redefinição da atuação do Estado no "centro" e na "periferia"

a) planificação indicativa (sociedade afluente)

b) planificação flexível (socie dade "sob" o Estado do Bem -estar)

Esta articulação entre países centrais e dependen tes cria uma sērie de relações e conflitos internos e/ou ex ternos bastante complexa e dá origem a um capitalismo cujas características são bastante peculiares. O impacto das rela ções capitalistas mundiais sobre uma área econômica, cujas condições objetivas para implantação do capitalismo estão au sentes, gera inümeras contradições. Porém, sob o mesmo im pacto, os países dependentes incorporam técnicas, idéias, ti po de organização que não correspondem ao desenvolvimento de suas forças produtivas internas. 
Esta articulação, também, modifica o caráter de intervenção pública quanto à reprodução da força-de-trabalho, na qual tem-se enfatizado o papel importante da saúde. O de senvolvimento capitalista, não reproduzindo, ipsis litteris, - modelo central, implica em que tanto o Estado como a repro dução da força-de-trabalho colocam-se de diferentes maneiras. 


\section{QUESTẼES METODOLÓGICAS}

Tendo em vista os objetivos anteriormente assinala dos e a complexidade do objeto analisado, optou-se por utilizar uma metodologia histórico estrutural, buscando uma abor dagem mais qualitativa embora considerando aspectos quantita tivos que servissem para fundamentar alguns fatos.

Tentou-se analisar as forças atuantes no período analisado e seguir alguns princípios de metodologia histórica, procurando identificar, como ressaltado por GRAMSCI (1978a: 189) "... os movimentos orgânicos (relativamente permanentes) dos movimentos que se podem chamar de conjuntura (e que se apresentam como ocasionais, imediatos)". Esta distinção, co mo assinalado pelo autor, é de grande relevância uma vez que "... verifica-se uma crise que, por vezes, se prolonga por dezenas de anos. Esta duração excepcional significa que na estrutura se revelaram (se amadureceram) contradições insanā veis e que as forças políticas positivamente atuantes para conservação e defesa da prōpria estrutura se esforçam ainda por curar, dentro de ditos limites, e por superar".

Em decorrência, tambēm, do tipo de abordagem ao ob jeto de estudo buscou-se uma periodização que marcasse rela ções de forças políticas existentes e sua interferência na solução das questões de saúde. Considerou-se a demarcaçãode datas em que ocorreram rupturas políticas, significativas na tentativa de solucionar os conflitos e acomodar os diferen tes interesses. A periodização, contudo, deve ser vista com 
ressalvas, uma vez que as propostas, as soluçōes são proces sos dinâmicos das classes sociais envolvidas e nestes proces sos, aquelas são, constantemente, recolocadas.

O período analisado estendeu-se de 1889 a 1978 e englobou quatro fases: 1) 1889 a 1930 ; 2) 1930 a 1945 ; 3) 1945 a 1964 e 4) 1964 a 1978. Compreendeu, ainda, um perío do anterior a 1889, uma vez que muitos dos elementos consti tutivos do primeiro periodo encontravam-se presentes antes desta data. Utilizando-se como critério as formas de governo, poder-se-ia classificar a primeira e terceira fases como democracia, ainda que com restrições e a segunda e quarta co mo ditadura.

Pretendeu-se situar a ārea de estudo no Estado de São Paulo. Contudo, dado o tipo de organização administratị va do Brasil, legalmente federativo embora caracteristicamen te unitário e centralizado, a anālise extrapolou esta área. Consequlentemente, conforme as formas de governo, esta análise é desigual com maior ou menor atenção para o Estado de São Paulo e maior ou menor aprofundamento nos períodos.

Os dados provêm das seguintes fontes:

1 - estudos realizados em diferentes áreas do conhecimento, publicados sob forma de livros, revistas, monografias, relatórios de atividades;

2 - documentos oficiais, compreendendo Mensagens do Executivo ao Legislativo, Decretos, Leis, Atos e notícias publi cadas no Diário oficial do Estado;

3 - entrevistas sistematizadas com cinco sanitaristas, abor- 
dando sua visão sobre Saúde Pública, sua inserção na área, opiniões sobre a organização e estrutura da secretaria de Saúde;

4 - informações eventuais e dispersas, fornecidas por diferentes sanitaristas em reuniões e encontros sobre temas de Saūde Pública. 


\section{SAUUDE PÚBLICA:- REPRODUÇÃO DA FORÇA-DE-TRABALHO OU LEGITIMAÇÃO?}

1. O CARÁteR EVENTUAL DA SAÚdE PÚBLICA:- AS COMISSÕES (ATÉ 1889)

Estudar a saúde Pública no Brasil, tendo como refé rência a questão Estado/Sociedade, é uma questão bastante cọn plexa. Essa complexidade torna-se maior pois, embora se pos sa servir das leis gerais do desenvolvimento capitalista, em seus aspectos econômicos e político-ideológicos, este desenvolvimento tem especificidades próprias, no Brasil, interferindo também na prōpria saúde Püblica.

Trata-se, assim, de analisar este objeto - a Saúde Pública - dentro de uma formação social, uma "... estrutura concreta, organizada e caracterizada por um modo de produção dominante e pela articulação à volta deste modo de um conjun to de modos de produção que a ele estão submetidos ..." (AMIN, 1976:12). Essa complexidade é mais ampla, dada a articula ção dessa formação social com outras via comércio a longa dis tância estabelecendo-se relações de dependência. Em suma,ca be considerarem-se os contornos específicos da sociedade bra sileira e nesta, a constituição da saúde Püblica.

Inserindo-se, tardiamente, no capitalismo mundial

e mantendo com os países centrais, uma relação de dependência, - Brasil percorre uma longa caminhada na dissociação entre trabalho e meios de produção. Dissociação ainda não total 
mente concretizada e, portanto, afeita apenas a pontos específicos e em diferentes graus.

O Brasil surge sob influência do feudalismo portụ guês em sua fase de transição para o capitalismo ou seja na fase mercantil do capitalismo. Sua articulação com os paî ses europeus dar-se-á através do comércio, contribuindo, de um lado, para a acumulação primitiva dos países europeus, via Portugal e do tráfico negreiro, e por outro para a constitui ção de economias regionais a ele ligadas.

A condição de colônia implica numa série de barrei ras para um desenvolvimento autônomo, uma vez que grande par te do excedente produzido é exportado, permanecendo, no país, apenas parcela dele que serve para a sustentação de um apare lho estatal, cuja finalidade principal é o escoamento da pro dução e sua fiscalização. Cabe evidenciar que algumas caraç terísticas das áreas de colonização, como a brasileira, apre sentam-se como obstáculos para o estabelecimento de relações capitalistas, que pressupõem, de um lado, o aumento de rique zas e de outro a existência de uma mão-de-obra livre, como assinala MARX (1971b:885):

"... nas colônias, a propriedade do dinheiro, dos meios de subsistência, de māquina e de outros meios de produção não transformam um homem em capital, se lhe falta o complemento, o trabalhador assalariado, - outro homem que é forçado a vender-se a si mesmo voluntariamente. Descobrir que o capital não é uma coisa mas uma relação social entre pessoa efe tiva por coisa..." 
Trata-se, portanto, do estabelecimento de relações sociais específicas, em condições que não existiam no país. O Brasil caracterizava-se por ser uma colônia onde eram co muns :

"... grandes extensões de territórios, podendo cą da colonizador transformar pedaços de terra em sua propriedade privada e meio individual de produção, sem impedir o que vem depois de fazer a mesma coi sa ..." (MARX, 1971b:887).

não havendo, nestas condições, dissociação entre trabalha dor e seus meios de produção.

E evidente que da maneira como se deu a ocupação de alguns espaços regionais, e com base na grande propriedade fundiāria, foi possível alcançar um certo grau de produti vidade, permitindo o desenvolvimento esporádico da região. Contudo, este desenvolvimento deu-se sob relações escravocra tas dominantes por quase três séculos $(1532$ - 1852) e que acompanharam os diferentes ciclos econômicos regionais: do açúcar (1550 - 1700), das minas (1700 - 1775) e parcialmente, do café $(1820-1870)$.

Pode-se afirmar ainda, que, até o século XVIII, as relações monetārio-mercantis praticamente inexistiam no Bra sil. Grande parte da riqueza social era medida em termos de posse da terra e número de escravos ou controle sobre trabalhadores estabelecidos nas propriedades.

A decadência das atividades econômicas, embora pre judiciais às oligarquias regionais, não as afetava profundamente, uma vez que a principal base econômica, a renda 
terra, não desaparecia e, inclusive, a parcela da mão-de-cbra empregada podia ser reaproveitada pelo estímulo a formas não -capitalistas de produção, por meio de concessão de terra a ser explorada sob forma de foro ou parceria, graças a qual, parcela dos trabalhadores, sem a propriedade dos meios de produção, tinha ainda acesso aos meios de subsistência, ainda que mínimos.

Assim sendo, não existiam ainda condições favorá veis ao desenvolvimento capitalista, no Brasil: uma parcela da mão-de-obra estava ligada à economia agro-exportadora, di reta ou indiretamente, e outra grande parcela à economia de subsistência ou seja, relações escravocratas e relações nãocapitalistas de produção.

E evidente que nem toda população inseria-se nes tas relações. Parte dela era lançada em situação de invalidez, miséria, de vagabundagem ou de roubo, o que è evidencia do pela existência de mecanismos de controle para esse tipo de indivíduos, mecanismos estes correspondentes às relações econômicas prevalentes. Predominantemente era a Igreja, atra vés das ordens religiosas, que assumia essa população com con trole e subvenção estatais.

Convém lembrar que às relações econômicas correspon dem relações ideológicas e políticas, transplantadas pela cô roa portuguesa para o Brasil. A colonização ou a conquista fez-se por meio do aprisionamento de índios e escravos, legi timada pelas ordens régias e pela evangelização; eram os co lonizadores e religiosos portugueses que se ocupavam das at vidades econômicas dominantes. Estes últimos participaramin 
tensamente destas atividades, em todo o Brasil até 1755; ao pretenderem "... assentar um imenso território temporal da Igreja Católica constituíam-se em importantes empresas comer ciais" (PRADO JR., 1956:73).

Se, de um lado, o escravo era assunto privado do senhor, assim como o eram os homens livres que viviam em suas terra, por ligações pessoais, de agregação, compadrio, por outro, às ordens religiosas ou às próprias famílias cabiam assumir os índios empobrecidos, os mamelucos, os invälidos, os doentes. Contudo, a assunção era bastante precária, in clusive pela falta de excedente destinado a esta tarefa e, inclusive, à evangelização.

Em 1803, o vigário de são Miguel, informava ao go vernador da Capital de são Vicente (são Paulo) sobre a "... impossibilidade d'elle poder existir com a insignificante porção que os moradores oferecerão a sua subsistência, e não devendo ser obrigados a contribuir com mais pela pobreza a que se veem reduzidos" (SPOSATI, 1987:65).

A emancipação política, em 1822, cujas bases foram lançadas pelo governo metropolitano e que somente transfere os poderes governamentais da metrópole para o Brasil, não destrói as relações não-capitalistas. A constituição de uma Nação ocorre sem sequer se ter iniciado o processo de forma Ção de uma burguesia e a soberania dá origem a um Estado, fun damentado nas relações escravocratas, cujo poder, apesar da feição burguesa, é evidentemente absolutista.

A Constituição de 1824 estabeleceu um governo uni tário, dividindo o país em províncias, com presidentes nomea 
dos pelo Imperador; adotou como forma de governo a monarquia hereditária e um sistema de representação, bas eado num sena do vitalício e numa Câmara de Deputados, eleitos pelos repre sentantes das províncias. Teriam direito ao voto aqueles que tivessem uma renda superior a $100 \mathrm{mil}$ réis por ano.

Trata-se, portanto, de um regime monārquico altạ mente centralizador e elitista, expressando os interesses das oligarquias regionais.

Enquanto o Estado burguês, em países centrais como Inglaterra e França, fundamenta-se na aliança entre a burgue sia comercial e industrial contra a nobreza feudal, a classe dos proprietārios, no Brasil são os proprietários rurais que constituem a Nação brasileira contra a burguesia mercantil daqui e do Reino (PRADO JR., 1957) e que se servem de princí pios filosóficos e políticos, como liberdade econômica e so berania nacional, para romper com a dominação portuguesa.

Verifica-se, portanto, a criação legal de um Estạ do Nacional, constituído de oligarquias latifundiārias regio nais. A constituição da Nação brasileira processa-se no fí nal da fase mercantilista e início da fase liberal ou concor rencial do capitalismo internacional, sob predomínio da In glaterra. Parece que não é sem razão que, no Brasil, desenvolvem-se as condições infra e supraestruturais para o iní cio da constituição de uma sociedade burguesa, quando a se gunda Revolução Industrial altera a produção de mercadorias e a produtividade pela introdução de motores a vapor e o ca pitalismo internacional busca novos mercados para seus produ tos manufaturados e de fornecimento de matērias primas. En 
tre as condições infra e supraestruturais, destacam-se:

1 - o estabelecimento da Lei no 601, em 1850, conhecida como Lei das Terras, como assinala IANNI (1976:7), "... a le gislação do Império cuidava para que as terras não estivessem demasiado disponíveis a quaisquer interessado.Hou ve preocupação em encarecê-las para evitar que os trabalhadores livres viessem a tornar-se facilmente proprietā rios, fugindo assim à condição de vendores de força-detrabalho ...". Em 1850, esta condição é legalizada para que seu acesso só fosse permitido não mais como uma con cessão, pelo menos para uma parcela da população, mas através do poder de compra.

"... o governo fixara para terras virgens um preço artificial, independente da oferta e procura. 0 imigrante teria que trabalhar longo tempo como aslariado até obter dinheiro suficiente para comprar terra e transformar-se em lavrador independente. As sim constituía um fundo extorquido do trabalho ... o governo utiliza esse fundo para importar pobres da Europa ..." (MARX, 1971b:892).

2 - Inicia-se processo de constituição, no Brasil, de uma mão -de-obra livre proveniente do Exterior (1). A própria

(1) As relações escravocratas, a desvalorização do trabalho manual, a possibilidade de reprodução em terras devolutas parecem ter sido obs táculos para incorporação da mão-de-obra nacional no processo capitā 1 ista, pois como assinala MARX (1971b:854) "não basta que haja, de um lado, condição de trabalho sob a forma de capital e do outro seres humanos que nada têm para vender a lém de sua força de trabalho. Tampouco, basta forçá-los a se venderem livremente. Ao progredir a produção capitalista, desenvolve-se uma classe trabalhadora que, por educação, tradição e costume aceita as exigencias daquele modo de produção como leis naturais e evidentes ...". 
Lei das Terras incorpora uma prática já utilizada pela Coroa, de importação de mão-de-obra subvencionada. Entre 1847 e 1857 instalam-se, no Estado de São Paulo, as primeiras colônias sob regime de parceria, como utilizadas em Minas Gerais. No entanto, esta experiência fracassa, pela intensa exploração da mão-de-obra que, ela própria custeando suas despesas iniciais de deslocamento, acabase ligada à propriedade. A partir da década de 1870, in troduz-se o colonato, regime de trabalho, que combina o trabalho assalariado e o fornecimento de moradia, de āreas de plantio e criação.

3 - Efetiva-se a abolição do tráfico negreiro, processo que se iniciou formalmente em 1821, sob imposição da Inglater ra, e que se prolonga até 1850, quando o número de escra vos entrados decai de 23.000 para 3.000 (PRADO JR., 1956: 155).

4 - Discute-se a questão da abolição da escravidão, processo iniciado, timidamente em 1871 e que se prolonga até 1988.

Alēm destes fatos, observa-se que as relações mer cantis tornam-se mais monetarizadas, a produção assume um ca ráter mais mercantil, inclusive parte da produção de bens de consumo necessários ao trabalhador; ou seja, cria-se um mer cado interno para a incipiente indústria nacional e local, estende-se a rede ferroviāria, fluvial e marítima, favorecen do a circulação de mercadorias. A propriedade privada e a introdução de uma mão-de-obra livre são ao mesmo tempo pres supostos da formação de uma burguesia nacional e consequên cia do capitalismo liberal, ao qual essa burguesia se vincu- 
lava, através dos financiamentos.

Porém, a constituição de relações capitalistas é regionalmente localizada, gerando outras regiões tributárias onde se reproduzem relações ainda não-capitalistas e não se constituem entraves para produção capitalista.

Como se apresenta a questão da saúde, neste regime monárquico? Como uma questão do domínio privado, familiar ou local e no máximo com um tipo de organização bastante pre cária e deficiente, as Comissões de Homens Bons (na Colônia), ou Probos (no Império), com funções filantrōpicas e/ou fisca lizadoras, nas quais os proprietários rurais participavam co mo meio de obter prestígio social.

Não que não houvesse problemas sanitários graves. A Tabela 1 mostra os coeficientes de mortalidade por algumas doenças, entre 1860 a 1900, Rio de Janeiro. Constatam-se ele vadissimos coeficientes de mortalidade por tuberculose em to do período. Todos os coeficientes mostram uma tendência de crescente, com alguns surtos de febre amarela. Na virada do século, a mortalidade por tuberculose ainda predomina, segui da pela malāria, varíola e febre amarela. 
TABELA 1 - Coeficientes de mortalidade por tuberculose (todas as formas), febre amarela, varíola e malária, por 100.000 habitantes. Rio de Janeiro, 1860 1900 .

\begin{tabular}{|c|c|c|c|c|}
\hline ANO & TUBERCULOSE & FEBRE AMARELA & MALĀRIA & VARIOLA \\
\hline $\begin{array}{l}1860 \\
1861 \\
1862 \\
1863 \\
1864 \\
1865 \\
1866 \\
1867 \\
1868 \\
1869 \\
1870 \\
1871 \\
1872 \\
1873 \\
1874 \\
1875 \\
1876 \\
1877 \\
1878 \\
1879 \\
1880 \\
1881 \\
1882 \\
1883 \\
1884 \\
1885 \\
1886 \\
1887 \\
1888 \\
1889 \\
1890 \\
1891 \\
1892 \\
1893 \\
1894 \\
1895 \\
1896 \\
1897 \\
1898 \\
1899 \\
1900\end{array}$ & $\begin{array}{r}1.221,86 \\
1.061,28 \\
1.140,09 \\
1.046,70 \\
924,22 \\
959,17 \\
957,48 \\
1.063,54 \\
961,12 \\
996,68 \\
974,33 \\
937,23 \\
796,17 \\
813,79 \\
781,16 \\
798,52 \\
759,69 \\
766,13 \\
790,96 \\
745,64 \\
715,14 \\
658,19 \\
650,18 \\
624,88 \\
565,20 \\
528,47 \\
561,62 \\
527,66 \\
499,51 \\
526,19 \\
512,27 \\
540,30 \\
485,53 \\
459,67 \\
450,20 \\
504,57 \\
536,08 \\
482,56 \\
499,13 \\
497,14 \\
500,25\end{array}$ & $\begin{array}{r}807,03 \\
156,12 \\
7,41 \\
4,23 \\
2,95 \\
-- \\
-- \\
-- \\
1,61 \\
143,51 \\
585,33 \\
3,74 \\
45,88 \\
1.567,20 \\
342,99 \\
516,36 \\
1.341,82 \\
105,13 \\
423,38 \\
338,58 \\
545,33 \\
83,24 \\
27,82 \\
484,94 \\
251,04 \\
124,82 \\
391,81 \\
35,69 \\
187,50 \\
521,11 \\
167,26 \\
1.012,45 \\
956,86 \\
178,79 \\
1.026,97 \\
169,08 \\
588,25 \\
31,34 \\
207,50 \\
137,39 \\
63,12\end{array}$ & $\begin{array}{c}-- \\
-- \\
-- \\
-- \\
-- \\
-- \\
-- \\
244,60 \\
243,23 \\
314,65 \\
368,71 \\
273,03 \\
449,30 \\
246,59 \\
362,89 \\
310,74 \\
274,76 \\
343,10 \\
266,27 \\
256,05 \\
207,95 \\
190,36 \\
287,10 \\
162,02 \\
211,78 \\
313,66 \\
244,94 \\
240,47 \\
496,94 \\
287,77 \\
501,81 \\
459,35 \\
254,65 \\
399,82 \\
361,53 \\
462,14 \\
226,89 \\
309,33 \\
251,10 \\
187,00\end{array}$ & $\begin{array}{r}85,93 \\
112,51 \\
174,97 \\
-- \\
-- \\
-- \\
-- \\
-- \\
55,07 \\
17,93 \\
176,96 \\
56,15 \\
414,28 \\
697,72 \\
238,32 \\
145,07 \\
65,23 \\
38,40 \\
783,04 \\
68,48 \\
9,06 \\
41,13 \\
292,89 \\
411,96 \\
26,18 \\
1,12 \\
44,34 \\
874,75 \\
42,92 \\
147,19 \\
83,98 \\
896,12 \\
81,88 \\
11,70 \\
18,20 \\
385,51 \\
85,01 \\
7,09 \\
12,51 \\
262,19 \\
108,27\end{array}$ \\
\hline
\end{tabular}

FONTE: RODRIGUES $(1967: 112)$. 
E evidente que, sendo a capital do país, centro ad ministrativo e político, esse quadro de mortalidade tornava -se aí mais evidente; contudo, é de se supor que as doenças grassassem em todo território nacional

Em 1820, constata-se um aumento de número de leprọ sos no Vale do Paraíba, zona cafeeira do Estado de São Paulo, "... uma região densamente povoada e de todas a mais próspera pelo desenvolvimento agrícola" (R. NETTO, 1942:18, 21);em 1846, ocorre uma epidemia de febre amarela em Salvador,Bahia (LABRA, 1985). Contudo, poucas medidas efetivas eram toma das, inclusive em 1837," ".. a verba de 1 conto de réis para vacina baixara para 400\$000" (R. NETTO, 1942:21).

Do mesmo modo, órgãos responsáveis pelo controle de doenças não faltaram. Segundo o Visconde de Uruguai (apud MASCARENHAS, 1973:434), "... os serviços de saúde pública no Império de 1828 a 1850 ficaram a cargo dos municípios que nada fizeram senão organizar alguns regulamentos para tentativas de saneamento do meio; de 1850 a 1889 , a centralização fez-se pela criação de órgãos centrais de saúde pública, se guidos, posteriormente, de órgãos provinciais e municipais, subordinados a um ōrgão central, tendo as municipalidades di reito de legislar sobre a saúde pública".

Para elaboração dos regulamentos constituíam-se as

(2) Nos casos de epidemias, fora o isolamento para algumas doenças, sustentada pela teoria do contágio, as medidas de prevenção com base em teorias sobrenaturais consistiam em dias de oração e penitências. Em 1768, o Morgado de Matheus mandou "... fazer separar os doentes em todas as vilas e rogar ao Reverendo Vigário Capitular que ordenas se preces públicas em todas freguesias da Capitânia" ( R. NETTO, 1942: 15). Dias de oração e penitências também eram frequlentes, nos séculos XVIII e XIX, nos Estados Unidos, como assinala TESH (1982). 
comissões: "... em 1854, o Presidente José Antonio Saraiva Maria havia nomeado uma Comissão de Médicos incumbida de apresentar bases para o regulamento da higiene preventiva, mas a comissão entendera que esse regulamento só deveria ser confeccionado depois de se constituir, em Santana, um lazare to para 200 morféticos. E como para isso não se dispusesse de verba ..." (R. NETTO, 1942:24).

Quanto ao direito das municipalidades de legislar, essa função parece precāria, mesmo considerando-se legalmente o período de descentralização política, entre 1820 a 1850.

SPOSATI (1987:66), analisando a Irmandade de Misericórdia, nota que "... quem a ela pertencesse possuía um status diferente. Tal honraria possibilitava que o paulista no se desvencilhasse do exercício da vereança ou de outros cargos públicos. Estes, não remunerados, exigiam ainda uma dedicação que obrigava a permanência no povoado e impediaque se tocassem "os negócios" mata adentro, no estilo paulistano". E possivel que esta "aversão" aos negócios públicos permanecesse ginda, no final do Império.

A existência de uma legislação sanitāria não efetí va sua aplicação, como mostra a mesma autora:

"... os fiscais da câmara, também, deveriam realizar inspecções e sugerir medidas adequadas, como por exemplo, em relação aos cortiços. Uma das sí tuações urgentes em são Paulo era solucionar a pre cariedade das moradias. Contudo, como consta de jornal da época, os fiscais temiam que as medidas mais efetivas comprometessem seu compadrio com os 
vereadores e que isso levasse a perda do seu empre go ..." (SPOSATI, 1987:77).

observando a existência de interesses associados no aparelho de Estado; dos fiscais, na preservação de seus cargos e dos vereadores, na sua política clientelística.

A normatização não se efetiva, também, porque a ex pedição de leis e normas para o estabelecimento de uma organização sanitária ocorre sem a implantação de estrutura admi nistrativa sanitária adequada, fato este comum na saúde Pú blica brasileira. As vezes, a própria ação a ser desenvolvida é uma atitude de um indivíduo, exercendo a atividade no domicílio e, submetido às regras formais, administrativas que orientam sua ação:

"O Instituto Vacínico, criado em 1838, ainda estạ va sem "organização regular" e por isso não havia prestado os bons serviços a que se destinava, fun cionando no domicílio do Dr. Comissário Vaccinador e Inspetor de vacinação, sem que fosse auxiliado por indivíduos de competência" (R. NETTO, 1942:23). Em 1886, ARRUDA (1936:100), inspetor de higiene da Província de são Paulo, aponta entre as necessidades da Pro víncia: "... montar e manutenir-se a repartição de hygiene que installada desde março do ano passado, continua a funcio nar em um escriptório médico manutenido a custa particular do Inspector de Hygiene que the fornece desde o papel, penna e tinta e até o aluguel da casa, acrescendo que mesmo assim a municipalidade exige que sejam pagos os direitos desse con sultōrio médico onde, cumulativamente e a expensas particula 
res, está desempenhando uma repartição pública, sem pagar aluguel".

Como nota R. NETTO (1942:24), os recursos eram mí nimos para o exercício da função sanitária:

"... no último ano da monarquia, reservara-se 597 contos ou apenas 0,4 웅 do total para a higiene pú blica, quando os minjistérios da guerra e da marí nha deviam absorver 19,6\%, as vias férreas 35\% e a imigração estrangeira 7\%."

Estes fatos, contudo, não devem ser vistos, negatí vamente, como uma demonstração de ineficiência, da crônica falta de recursos dos órgãos públicos. Muito pelo contrārio, devem ser vistos em seu carāter positivo, na sua contribui ção para implantação de uma legislação sanitária, de uma es trutura burocrática e na preservação dos vários interesses que o aparelho estatal incorpora. Observa-se que as ações e os indivíduos são absorvidos, posteriormente, na estrutura organizacional, preservando, também, os interesses particula res, pelo regime jurídico de trabalho.

Essa "organização embrionária", já regida por uma série de normas legais, não desaparecerá na República.

2. A FORÇA-DE-TRABALHO E A CONEXÃO INTERNACIONAL (1889$1930)$

A República, em 1889, representa mais uma etapa na 
constituição de um Estado-Nação, mas não destrōi as oligar quias regionais e nem os resquícios monárquicos, centralizadores. Estabelecendo uma série de direitos e liberdades bur guesas (a Constituição, a Assembléia de duas Câmaras, amplia ção de direitos eleitorais), processo inerente à expansão e consolidação de uma sociedade de classes combina os interes ses das diferentes oligarquias regionais, sob a hegemonia da burguesia cafeeira (mineira e paulista), interesses estes em oposições e que se expressam nos conflitos entre uma centra lização estatal e descentralização regional, que marcam este período e que o Estado Novo tentarā solucionar.

A Constituição de 1891 adota um sistema federativo, constituído de estados autônomos; um sistema de representação composto de Câmara de Deputados e Senado Federal, eleitos por sufrágio universal; segundo FAUSTO (s/d:9) "... ela representa uma vitória dos grandes Estados ... deu-lhes ampla autonomia para contrair empréstimos externos, constituir for ças militares próprias e uma justiça eleitoral. Garantia a supremacia regional da oligarquia paulista e mineira, sem es facelar o Poder Central ...".

Como nota RODRIGUES $(1967: 23,24), "$... Os nossos legisladores e constituintes da época, tomando como paradig ma os Estados Unidos da América, estruturam o Brasil e deram - Ihe uma Carta Magna, inspirada naquele país amigo. Entretan to, as origens e a formação dos Estados Unidos foram comple tamente diversas das que determinaram a nossa República .... O Estado è uma entidade autônoma e soberana para resolver e decidir sobre todos os assuntos internos, ficando a atribui 
ção federal limitada aos assuntos que digam respeito à rela Ção entre os Estados ou à alçada internacional. Este espírí to que se procurou outorgar ao Brasil com a Constituição de 1891, magnífico do ponto de vista da concepção, falhou na ba se, isto é, a situação de fato das então chamadas Províncias do Brasil" onde "... cada Estado reger-se-á pela Constitui ção das leis que adota, respeitados os princípios constitucionais da União..." .

E este poder central, sob hegemonia da burguesia cafeeira, que iniciará a incorporação da Saúde como uma área de atividade estatal, sua forma de organização, os momentos e os locais de sua atuação.

Em momentos "normais", a saūde não se caracteriza por ser uma área específica, tanto que os recursos a ela des tinados encontram-se englobados em "Socorros Públicos", mos trando ainda seu carater filantrópico e emergencial. A exis tência de recursos, contudo, serve às duas finalidades: a subvenção das entidades filantrópicas e a política clientelís tica, como mostra MASCARENHAS (1949:18):

"... as verbas, consignadas de 1892 a 1930, na ru brica de Socorros Püblicos... criadas, inicialmen te, para o combate as epidemias foram desvirtuadas. Tornaram-se ... propriedade de deputados estaduais. Cada deputado tinha uma certa proporção dessa ver ba e a distribuía pelos hospitais de sua zona elei toral sem controle algum por parte das autoridades sanitárias. Presumimos, sem poder afirmar com se gurança, que parte das verbas dessa rubrica era 
encaminhada às Prefeituras Municipais para obras de saneamento. Em alguns casos, eram utilizadas en carácter provisório para pagamentos de funcionários dos serviços sanitários. Em vésperas de eleições, essas verbas eram aumentadas quer diretamen te, quer indiretamente através de suplementação, o que mostra o cunho político das mesmas ...".

Em caráter emergencial, deslocam-se recursos de ou tras fontes, como nota R. NETTO (1942:25), "Rodrigues Alves ... tentou, às vésperas da República facultar os incipientes serviços de higiene e saúde de são paulo a autoridade e os recursos necessários para torná-los satisfatoriamente efica zes. Para isso, fez retirar $25.000 \$ 000$ dos créditos de imi gração, sempre folgados afim de distribuí-los do seguinte mo do:

\footnotetext{
Hospital de isolamento de contagiados .. 6:000\$000 Instituto Vaccinogenico ........... 3:000\$000 Laboratório de Análises Químicas ..... 2:000\$000 Hospedaria dos Imigrantes ......... 2:000\$000 Gratificação aos Inspetores de Higiene e outros empregados da reparti ção ......................6:000 6000

Melhor acomodação da mesma repartição .. 6:000\$000 Constata-se, portanto, que, mesmo na República, ape sar do quadro de morbidade e de alta mortalidade, as ques tões de Saúde Pública eram tratadas como ārea nãó específica e seus recursos, destinados à assistência médica-hospitalar ou outras. As doenças e suas conseqthēncias são solucionadas
} 
predominantemente, fora do âmbito público, em nível privado, pelas famílias e entidades filantrópicas, estas mantidas pe las contribuições de proprietários rurais e/ou auxílios e subvenções governamentais.

Neste sentido, a Saúde Pública, como uma área espẹ cífica de atuação não se institucionaliza, apesar das tentativas de organização e não se institucionaliza, inclusive,por ausência de uma feição própria, fundamentada num saber específico, combinando atividades assistenciais (sociais ou médi cas) e fiscalizadoras. E apesar das leis, decretos, normas, ela não ganha muita expressão, nas diversas Constituições desde 1824 até 1964, tendo alguns de seus aspectos incorpora dos à legislação trabalhista, após 1930.

Internacionalmente, contudo, em meados do século XIX, ou antes, a questão do controle de doenças transmissí veis, cujas medidas impediam a circulação, torna-se um pro blema econômico e político. Em 1851, realizava-se, em Paris, - 10 Congresso Internacional de Saúde com 12 delegados, cujo debate fundamental girava em torno da teoria da causalidade de doenças, opondo-se os miasmäticos e os contagionistas (HOBSON, 1965:5).

TESH (1982:328) assinala como a ideologia liberal suprime a teoria do contágio, encontrando sua sustentação for te oposição entre médicos liberais e novos industriais. Nota que :

"Lacking sufficient scientific evidence to the theory, they dressed up contagionism in symbolic garb that linked it to the ancien regime.Contagionism 
they implied, was the province of vapid mentalities of people with no sense of progress, leftovers from prescientific era who revered authority for its own sake. They called quarantines ineffective and wasteful, and charged that closing was mere mindless bureaucracy. In constrast, they presented the atmospheric or anticontagionist hypoteses as a new idea, consistent with the ideals of progress, individualism and freedom that guided the Industrial Revolution."

Gualtier, escrevia, em 1833, "... quarantine is useless and the injury it inflicts on the commercial relations and maritime intercourses of the country is an absolute and incompensated evil ..." (apud TESH:328) (3).

No Brasil, "... O Decreto 1558 de 07 de outubro de 1892, assinado por Floriano Peixoto estabelecia que a carne de charque, entre outros artigos, era ... suspeita ou suscetivel de reter ou transmitir contágio levou a uma série de reclamações, pelos incovenientes que provocara ao comér cio internacional ..." (GARCIA, 1984:86). A chamada "guerra da quarentena" entre Brasil, Argentina e Uruguai, em 1893, correspondeu em grande parte às lutas internas entre diferen tes setores da burguesia do Brasil" (GARCIA, 1984:29).

(3) Portanto, parece incorreta a afirmação de BLOUNT (1972) de que os partidários da saúde pública paulista recorriam a argumentos econômi cos, ao conträrio, que os americanos e europeus cujos argumentos eram mais humanitários. TESH (1982) mostra que as medidas de contro le de doença sempre se associaram a interesses econômicos e políticos, em diferentes épocas, tanto nos Estados Unidos como na França. 
Em 1895, sob pressões internacionais da burguesia externa que controlava o comércio exportador no Brasil, e in ternas da burguesia cafeeira, as restrições impostas pelo de creto acima referido são anuladas. São estes mesmos interes ses que resultam na criação de una Diretoria Geral de saúde pública, subordinada ao Ministério da Justiça e Negōcios In teriores e no saneamento dos principais portos. Como nota FAUSTO (s/d:9) "... burguesia cafeeira não foi simplesmente beneficiária da ação do Estado mas forjou as instituições estatais e transformou-as no instrumento de seus interesses."

O aparecimento, em 1899, da peste bubônica, em Santos, marca a chegada, na América, da pandemia mundial que havia começado no Extremo Oriente, em 1894. De Santos, a doença alastrou-se para o Rio de Janeiro em 1900 e em ambos os Estados, essa situação possibilitou a instalação de laboratōrios de produção de soros e vacinas, Butantã e Mangui nhos (STEPHAN, 1976), incorporando-se a alguns institutos e serviços de saúde já existentes.

Entre 1898 a 1910, ocorrem, no Brasil, as primei ras campanhas sanitárias em todos principais portos brasilei ros (Santos, Rio de Janeiro, Recife) (4), integrando-se a um vasto programa de saneamento marítimo em nível mundial e sob imposição do imperialismo internacional.

E evidente que estas Campanhas, através de medidas de saneamento dos portos, de extinção dos cortiços, resultaram em alterações dos coeficientes de mortalidade, que já vi nham decrescendo (v. Tabela 1) mas, como nota costa (1985:

(4) Para Recife, v. MELlo, M.A.B.C. (1985). 
64), apesar das Campanhas Sanitārias, "... a dita mortalida de causada pela varíola continuou a dizimar contingentes pon deráveis da população e a significar uma ameaça à força-detrabalho a um mal incontrolável mesmo entre as classes domi nantes", como provavelmente a malāria, a tuberculose, doen ças que ainda, em meados do século xx, continuaram a ter im portância fundamental.

O que parece relevante na Saúde Pública brasileira é que não é na reprodução da força-de-trabalho, em âmbito da produção, que reside sua primordial função, mas, essencialmen te, na circulação e distribuição de mercadorias, inclusive da mercadoria força-de-trabalho estrangeira. A imigração estrangeira contava com significativa subvenção governamental, como mostra a Tabela 2 .

TABELA 2 - Total de imigrantes e porcentagem de imigrantes subvencionados, Brasil 1888 a 1915.

\begin{tabular}{lcc}
\hline Periodo & $\begin{array}{c}\text { Total de } \\
\text { imigrantes }\end{array}$ & $\begin{array}{c}\text { \% imigrantes } \\
\text { subvencionados }\end{array}$ \\
\hline $1888 / 1890$ & 152.240 & 63,4 \\
$1891 / 1900$ & 719.595 & 79,4 \\
$1901 / 1910$ & 420.447 & 40,1 \\
$1911 / 1915$ & 356.045 & 36,0 \\
\hline
\end{tabular}

FONTE: CARDOSO (1977:25).

Observa-se que, entre 1891/1900, ocorre maior en trada de imigrantes e, consequentemente, maior subvenção, de caindo, paulatinamente até sua extinção. Imigração essa que contribuiu, entre 1890 a 1940, com o valor estimado de 10,0\%, 
conforme LEVY (1974) para o crescimento populacional. Por a tro lado, desde 1870, as taxas brutas de mortalidade vinham decrescendo, enquanto as taxas brutas de natalidade permane ciam altas, possibilitando um elevado crescimento vegatativo, Tabela 3 .

No Estado de São Paulo, observa-se uma taxa de cres cimento de 3,6\% ao ano, entre 1872 a 1900, contando, também, com o excedente de mão-de-obra de regiões economicamente de menor produtividade, conforme observa FURTADO (1971).

TABELA 3 - Taxas brutas de crescimento de natalidade e morta lidade, Brasil, 1870 a 1970/1.000 habitantes.

\begin{tabular}{lccc}
\hline Periodo & $\begin{array}{c}\text { Taxa Bruta } \\
\text { de } \\
\text { Natalidade }\end{array}$ & $\begin{array}{c}\text { Taxa } \\
\text { Bruta } \\
\text { Mortalidade }\end{array}$ & $\begin{array}{c}\text { Taxa Bruta } \\
\text { de } \\
\text { Crescimento* }\end{array}$ \\
\hline $1870-1875$ & 46,33 & 31,12 & 15,21 \\
$1875-1880$ & 46,66 & 30,19 & 16,47 \\
$1880-1885$ & 46,77 & 29,10 & 17,67 \\
$1885-1890$ & 46,55 & 28,00 & 18,55 \\
$1890-1895$ & 46,32 & 26,84 & 19,48 \\
$1895-1900$ & 46,33 & 25,71 & 20,62 \\
$1900-1905$ & 46,53 & 24,61 & 21,92 \\
$1905-1910$ & 46,69 & 23,61 & 23,08 \\
$1910-1915$ & 46,61 & 22,69 & 23,92 \\
$1915-1920$ & 46,46 & 21,87 & 24,59 \\
$1920-1940$ & 44,37 & 24,94 & 19,43 \\
$1940-1950$ & 44,37 & 20,60 & 23,77 \\
$1950-1960$ & 43,32 & 13,43 & 29,89 \\
$1960-1970$ & 37,73 & 9,43 & 28,30
\end{tabular}

* Somente o crescimento vegetativo (Natalidade-Mortalidade). FONTE: MADEIRA apud POSSAS (1978:82). 
Consequentemente, dada a essa disponibilidade de mão-de-obra, è pouco provável que se colocasse como fundamen tal a reprodução da força-de-trabalho. são interesses predo minantemente comerciais e financeiros (internos, regionalmen te localizados e externos) e os investimentos neles envolvi dos, que determinam as Campanhas e não interesses propriamen te produtivos.

Na zona rural, o próprio regime de colonato combinava salārio em dinheiro e em espécie, fornecendo ao colono habitação e áreas de cultivo e de criação. Esse regime era necessārio para funcionamento da produção cafeeira em duplo sentido, de um lado, o fornecimento de moradia favorecia um certo grau de estabilidade dos colonos; por outro lado, per mitia a regeneração da força-de-trabalho e o desenvolvimento de uma prole, tanto em área rural como urbana, como indica a existência de colônias e vilas operārias (5).

E evidente que a produtividade do trabalho era um elemento importante e neste sentido, o saneamento terrestre através do controle de doenças debilitantes como a ancilosto míase e a malāria, teve sua importância e principalmente, nas zonas cafeeiras do Estado de são Paulo. Contudo, mais do que isso parece que o intenso fluxo migratório, o regime especial de trabalho vigente, e a permanência de relações não capitalistas nas áreas rurais brasileiras, tiveram um papel fundamental no crescimento da população brasileira e, dada às condições específicas do desenvolvimento capitalista, pos

(5) Neste aspecto, cabe ressaltar os obstáculos para estabelecimento de relações tipicamente capitalistas, analisadas no item 1. 
sibilitaram a ampliação de uma mão-de-obra excedente.

Cabe notar, inclusive, que as relações capitalis tas de produção não eram predominantes, mesmo nos raros cen tros urbanos, onde o processo de industrialização era ainda incipiente e compunha-se de pequenas empresas de produção de bens de consumo não duráveis e destinados a mercados locais. Mesmo, as indústrias existentes no interior de são Paulo (e provavelmente em outras regiões) estavam ligadas aos interes ses comerciais e financeiros de grandes empresārios, não dis pondo de māquinas próprias, utilizando-se de um sistema de arrendamento (IYDA, 1979).

Com as considerações acima, quer-se assinalar que a não ser em pequena escala, não há generalização de relações capitalistas, mesmo no setor industrial.

Neste sentido, as Campanhas Sanitárias tiveram uma outra face, a de estabelecer, dentro dos princípios prevale centes de ordem e progresso, uma área específica de atividade estatal e sua organização, em nível nacional. Tratava-se de estabelecer um consenso sobre a legitimidade dessa ação estatal, legitimidade essa dada pela utilização de meios ra cionais, científicos. E, sem dúvida nenhuma, tanto Oswaldo Cruz como Emilio Ribas, foram fundamentais na construção des ta legitimidade, pelo prestígio científico que gozavam nos meios intelectuais e coerência com os ideais republicanos ${ }^{(6)}$.

(6) Emílio Ribas fundou, em 1888, um Club Republicano, "... moço de idéias adiantadas e espírito democrata não se fez esperar a sua ação em favor da Democracia. E assim que, a 29 de julho de 1888, como distincto republicano que era convocou com outros amigos e correligionários uma reunião, à qual compareceu representantes de três partidos militantes e fundou o Club Republicano..." (Arq. Hyg., 1936:42). 
A ação do primeiro ganha maior expressão nacional, não somen te em virtude das circunstâncias econômicas e políticas em que ocorrem as Campanhas Sanitárias (movimentos contra o cus to de vida, de tentativa de golpe militar), como também, pe lo fato de ter tentado implantar um modelo de organização em nivel nacional, por meio das Missões Científicas, utilizado pelos colonizadores europeus, na África, Ásia e América, e que consistia no envio de missões para obter material ou rea lizar estudos e regressar ao centro, deixando um embrião, uma reprodução da organização existente na Metrópole (GARCIA, 1984) (7). Uma alternativa semelhante a esta, era seguida pela Fundação Rockfeller:

"A Fundação motivara o interesse dos Estados por determinados problemas. Propunha-lhes modelos de organização e operação. Fazia demonstrações orien tadas para se constituírem em normas teóricas e prática. Não descuidava da legislação necessária. Introduzia tecnologia e financiava os primeiros pas sos para deixar a totalidade dos custos e necessidades, geradas pelo modelo nas mãos do governo" (FRANCO-AGUDELO, $1984: 121$ ).

E estes modelos estavam estritamente vinculados aos interesses econômicos, de ocupação de áreas:

"... Como os colonizadores europeus, grande parte dos primeiros trabalhos de saúde pública no estran geiro feito por americanos, inclusive a pesquisa

(7) Oswaldo Cruz desenvolveu em fins do século passado, estágio de estu dos e de aperfeiçoamentos em Paris (FONSECA FILHO, 1974). 
científica, era relacionada diretamente não apenas aos negócios, mas também às necessidades militares do imperialismo ..." (CLEAVER, 1984:51; FEE, 1987). Segundo GARCIA (1984:51, 53):

"... em 1900, o Departamento Médico do Exército dos Estados Unidos nomeou duas comissões para estụ dar as doenças tropicais, a primeira nas Filipinas e a segunda em Cuba... Entre 1898 e 1901, Gorgas, médico do Exército, havia tentado erradicar a fe bre amarela, sem êxito, com base na limpeza do por to de Havana, de acordo com o pensamento da época. .. Em março de 1901 , Gorgas mudou a estratégia, ao levar em conta a quarta comissão norte-americana que havia confirmado a teoria de Finlay, segundo a qual o mosquito transmitia a febre amarela, conse guindo em seis meses a erradicação da doença ...".

No Brasil, Emílio Ribas, nomeado diretor do Serviço Sanitário do Estado em 1898 e encarregado de acabar com epidemia de febre amarela, principalmente em Jaú e Campinas, começou, em dezembro de 1902 , "... uma experiência seguindo as pegadas da Comissão Norte-Americana de Cuba, presidida por Reed; mosquitos infectados por terem picado doentes no Inte rior, foram trazidos à Capital ..." (MASCARENHAS, 1973:432).

Esta experiência teve apoio do governo central: ". .. - Presidente Rodrigues Alves autorizou (Pereira) Barreto, Ribas e Adolfo Lutz, diretor do Instituto Bacteriológico, a realizar uma série de experiências de inoculação em seres hụ manos a fim de confirmar a descoberta da Comissão Reed" (STEPHAN, $1976: 84$ ). 
No Rio de Janeiro, Sales Guerra convidado a assumir a Diretoria Geral de Saúde Pública, "... recomendou Os waldo Cruz, com quem havia estudado as novas descobertas de Reed. Oswaldo Cruz esboçou para (Rodrigues) Alves um plano de ação ambicioso contra as três doenças epidêmicas no Rio, passiveis de controle imediato:- a febre amarela, a varíola e a peste ... e ao assumir o cargo de Diretor mandou um de legado a Havana para observar o trabalho das autoridades ame ricanas em Cuba" (STEPHAN, 1976:86).

Estabelecia-se, assim, O que LABRA (1985:25) denominou a conexão internacional, favorecida pela criação, em 1902, da Oficina Sanitāria Panamericana - OPS - "... como um mecanismo para que os Estados Unidos pudessem implantar certas medidas relativas ao saneamento marítimo ..." como as sinala GARCIA (1984:37) ficando as empresas industriais-fí nanceiras, como a Fundação Rockfeller, responsáveis pelo sa neamento terrestre nas Campanhas contra Doenças Debilitantes (Ancilostomiase e Malária). Esta conexão marcará a Saúde Pública no Brasil e a organização dos seus serviços saūde.

FONSECA FILHO (1974) assinala que as primeiras e as diferentes Missões do Instituto Oswaldo Cruz atendiam às solicitações de entidades püblicas e privadas, entre as quais o próprio Ministério das Relações Exteriores.

Em 1906, a Missão desloca-se para Itatinga (SP) pa ra possibilitar "as obras de construção de usina hidro-élētri ca empreendida pela Companhia Docas de Santos, suspensas de vido a epidemia de impaludismo que grassava entre trabalhado res ...", realizando, no Brasil, a primeira campanha anti-ma 
lária, e posteriormente, em Xerém (RJ) para possibilitar os trabalhos de prolongamento de abastecimento de água; em Mi nas Gerais, para o prolongamento das linhas da Estrada de Ferro Central do Brasil até Pirapora. Na mesma época, Arthur Neiva é encarregado de importante campanha contra malária "que estava prejudicando a construção da Estrada de Ferro No roeste do Brasil, no Estado de São Paulo" (FONSECA FILHO, 1974 : 19).

Em 1910, Oswaldo Cruz, a convite dos dirigentes da Estrada de Ferro Madeira-Mamoré, associada a "Port of Pará", empresa americana, inicia a campanha contra febre amarela, no Parā, que jā havia experimentado uma epidemia, em 1850, com elevada mortalidade, como assinala FRAIHA (1972). Relata, ainda, o autor que, quando esses dirigentes decidiram recorrer a Oswaldo Cruz, este apresentou ao governador as condi ções que deveriam ser indispensavelmente observadas, entre as quais, "a adoção pelo Estado, dos regulamentos sanitários em vigor do Distrito Federal e dos que regem os serviços sa nitários dependentes da União; criação de uma Comissão Sanitária de Profilaxia da Febre Amarela, sendo esta comissão in teiramente autônoma ... execução das medidas coercitivas de que cogitam os aludidos regulamentos, por via administrativa e pela Comissão de saneamento" (FRAIHA, 1972:35, 36). Alēm destas condições, estabeleciam-se, por leis e decretos esta duais, os recursos financeiros e materiais indispensáveis, contribuindo para a eficácia das campanhas.

Tanto na lei que instala o Serviço de Profilaxia de Febre Amarela, no Pará, quanto no decreto que cria a co 
missão, estabelecem-se que "em caso de antagonismo

entre leis estaduais e federais vigorarão sempre estas ..." e "... para acorrer às despesas com o serviço de profilaxia de febre amarela ... fica o Governador do Estado, autorizado a abrir os créditos necessários e a fazer operações de crédito, se achar conveniente ..." (FRAIHA, 1972:47, 49).

Em 1919, quando se reorganiza o serviço de profila xia rural, "o governo, visando a que fossem executadas as instruções do Ministério do Interior na forma estabelecida, condicionou a liberação das verbas à obediência as diretrizes do Centro, mediante declaração prévia desse compromisso por parte dos Estados ... Para os Estados que contratassem a assistência da Fundação Rockfeller, a União se comprometia a entrar com um auxílio de $25 \%$ das despesas ..." (LABRA, 1985: 104) que, como mostra FRANCO-AGUDELO (1984), possibilitava a essa Fundação a exigência de manter a direção e o controle sobre o programa empreendido.

Em 1919, a "... Sociedade de Medicina e Cirurgia da Bahia elevou veementemente seu protesto contra o que con siderou intromissão indevida da Diretoria Geral de saúde, ex pressando "... a tutela que a saúde püblica federal nos quer impor é inadmissível e fere nossos brios ... Não obstante,no mesmo ano, houve um surto de febre amarela nesse Estado, so licitando-se ajuda federal. O Ministério do Interior, atra vés da Diretoria de Saúde, impôs uma série de restrições "in sólitas, inéditas e descabidas aos passageiros provenientes da Bahia, instituindo passaportes sanitários e quarentenas aos viajantes... medidas que, aliás, há muito tempo Oswaldo 
Cruz tinha extinto" (LABRA, 1985:107).

São estas medidas coercitivas, extintas em 1919 que marcam, também, os mecanismos utilizados e incorporados na organização sanitāria, como em qualquer órgão estatal no con trole de massas populacionais.

GARCIA (1984) chama a atenção para o fato de que a origem do Saneamento estatal americano surgiu nos serviços de hospitais da Marinha e que os diretores da organização Panamericana de Saúde (de 1902 a 1947) provinham desses ser viços ou do Public Health Service. Ora, esse fato imprime às campanhas sanitárias o enfoque conceitual e organizacional da corporação militar. Como assinala MANHEIM (1962:264, 265) o verdadeiro pioneiro na história das modernas técnicas sociais "... foi o exército dos Estados absolutistas porque foi a primeira grande instituição que não só previu os métô dos racionais de criar artificialmente um comportamento uni forme das massas por meio da disciplina militar e de outros recursos para superar o medo, mas também, usou estes métodos para educar grandes massas (em sua maioria das classes mais baixas) a agir e, se possível, a pensar, de determinada for ma".

E evidente que a criação deste comportamento uni forme incorpora-se em elementos ideológicos de "combate ao inimigo, às doenças" e cria uma identidade universal como se as doenças atingissem indiferencialmente todos os indivíduos, gerando um espírito de união, um consenso que dā legitimida de às ações, inclusive, a possibilidade de utilização da coerção física. 
GAMBETA (1984) demonstra este fato, ao analisar o saneamento da cidade de Santos, cidade portuária que cres ce entre 1886 a 1900, em 223\%. Ligada ao interior do Estado, em 1868, por uma rede ferroviāria, experimentou, em 1889 uma epidemia de febre amarela e em 1899, a entrada da peste bubô nica. Cidade-acampamento de muitos imigrantes, sem infraestrutura habitacional, vê proliferar as "casas de cômodos", nela amontoando a população trabalhadora. Em 1891, o governo contratou um engenheiro sanitário da Universidade de cor nell para projetar o saneamento geral de Santos. Em 1893, é formada uma Comissão Sanitária com "... um poder paralelo se não preponderante à Intendência Municipal" (GAMBETA, 1984: 22) para extinção dos cortiços, altamente prejudiciais à saụ de, estabelecendo o conflito entre as duas instâncias.

Para a Comissão Sanitāria, a extinção dos cortiços não deveria ser protelada. A troca de ofícios com a Intendên cia Municipal de Higiene, em fevereiro de 1892, o deixa claro. Assim dirigia o Intendente à Comissão Sanitária:

"Quase diariamente, com a solicitude que vos des pertam a salubridade desta terra e a responsabilidade do cargo que dignamente exerceis, requisitais de mim a demolição de cortiços, realmente imprestáveis, e manifestais o desejo de que a extinção destes casebres se torne efetiva imediatamente após - prazo conceđido por ocasião da intimação. Penso convosco que há necessidade absoluta de eliminardo perímetro urbano estas construções viciosas, antihigiênicas e altamente nocivas à saúde daqueles 
mesmos que os habitam; no entanto, sou forçado a confessar tambēm que, rigorosamente possível uma ou outra demolição, nem todas são possíveis, por que uma vez desalojadas as famílias que moram nes tes cortiços, não terão recurso de achar casa para habitarem de acordo com os recursos de que podem dispor. Não ignorais as dificuldades que aqui exis tem no que diz respeito a casas de aluguel para as classes pobres, de modo que demolindo os cortiços em que elas habitam pratica-se o ato violento de enxotá-las para a rua, uma vez que nem temos cômodos provisórios, em forma de galpões, para abrigar temporariamente estas famílias." (GAMBETA, 1984: 24)

Dois dias depois o Chefe da Comissão Sanitária lhe responderia:

"Compreendeis facilmente que a Comissão Sanitāria não pode nem deve contemporizar e tão pouco ter con templação, pois de outra forma será iludir a confiança que nela deposita o Governo do Estado, que, com louvável intuito, enviou-a para esta cidade. (...) Penso ser preferível que os seus moradores sejam obrigados a residir em outro (lugar), mesmo acumulados, observados certos preceitos higiênicos, do que permanecerem em verdadeiros focos de infec ção constantes e permanentes." (GAMBETA, 1984:24,25) Na medida em que o fundamental era o saneamento dos portos, diante dos impasses, prevalecia o organismo estadual, 
apoiado no Código Sanitário e em nome da salubridade.

"... com o sabor de "dever cumprido" assim relata um zeloso inspetor sanitário: ... Quando intimidava a demolição de algum cortiço e não era cumprida a minha resolução no fim do prazo determinado, era aplicar a multa e imediatamente fazia demolir por uma turma de operários, garantida a boa marcha do serviço com a presença de praças, requisitadas às autoridades competentes." (GAMBETA, 1984:22)

Observa-se que, quando as medidas legitimadas pela ciência, não eramsuficientes, contrapondo-se às reais condi ções de vida, provocando resistências, estas só são removí das à base da utilização de uma coerção maior. Do ponto de vista imediato, soluciona-se o problema localmente, gerando os mesmos problemas em outras āreas e a utilização dos mecanismos de controle. As medidas, impostas pela Comissão Sani tária "obrigação de residir em outro (lugar) mesmo acumulados, observados certos preceitos de higiene", disseminam a pobreza acumulada como recomenda o engenheiro sanitarista america no e resulta, conforme Simonsen, "... na preferência da classe operária pelas casinholas de madeira em pleno campo, livre da ação disciplinadora da higiene e ... do fisco." (apud GAMBETTA, $1984: 26$ )

Contudo, em 1920, com o saneamento terrestre, na Campanha da Ancilostomíase, esta população foi novamente al vo de atenção profilātica.

"Lá vem o Doutor da Comissão Sanitária subindo o Morro de são Bento com seus auxiliares fazendo lis 
tas de moradores, exigindo amostra de suas fezes, receitando vermífugos, impondo uso de calçados, convencendo ou reprimindo." (GAMBETA, 1984:26)

Esta forma de institucionalização da saúde Füblica integra-se a um quadro mais amplo do novo regime governamen tal, a República. Ela não representa apenas uma nova forma de governar, mas tambēm, novas bases de legitimação. Apesar de federativo, o regime republicano preserva traços centrali zadores e autoritārios do regime monārquico, motivo das frequentes discussões quanto à presença do governo federal nas atividades governamentais locais. Como uma nova forma de re gime, correspondente ao desenvolvimento econômico que se ini cia em meados do século XIX, a República não pode buscar seus fundamentos ideológicos nos princípios religiosos, mas naqueles que representam a ordem econômica em desenvolvimento. Princípios estes que jā predominavam nas formações sociais eu ropéias e norte-americanas e especificamente, o positivismo, onde se encontram os ditames da ordem e estabilidade social, necessários ao regime político.

Segundo SIMON (1986:129) "... as idéias de Comte encontraram um solo fërtil no Brasil. Suas primeiras manifes tações datam de 1850, em teses de doutoramento da Escola de Medicina e da Escola Militar mas só a partir de 1870 , a dis cussão dos temas positivistas deixa a academia para interferir na política."

Assim se expressa IANNI (1983:66, 67):

"Da mesma forma que o catolicismo havia sido a dou trina básica dos governantes durante o período mo 
nárquico (1822-89), o positivismo passa à catego ria de doutrina principal no período republicano. Ao mudar a composição de forças do bloco do poder, modifica-se também a ideologia dominante. E inegável que o positivismo influenciou bastante $\circ$ pen samento orgânico das classes dominantes, ao longo da primeira fase da república (1899-1930) ... favo receu o militarismo e o forte predomínio do apare tho estatal em amplas esferas da vida social ... a repressão contra os movimentos sociais rurais e ur banos - Canudos, Contestado, protestos contra a va cina obrigatória e outros - foi a contrapartida an tipopular e antidemocrātica da ordem e progresso." E para esta "ordem e progresso" que passa a haver uma necessidade de uma referência unificadora e identificado ra em relação à saúde. Do mesmo mesmo que, a partir da Repú blica, tenta-se criar uma identidade social em torno da Na ção, elemento constituinte da sociedade burguesa e que, legalmente, inicia-se com a Independência, o mesmo processo ocorre com a Saúde Pública, o Estado, responsável pela saúde da população; do senhor de escravo e das ordens religiosas para uma entidade mais abstrata.

Tratava-se, em resumo, de constituir uma esfera da ação estatal, a Saúde Pública, sua área de atuação e sua es pecificidade, a autoridade legalizada e as formas organizacio nais, e um corpo de funciónários, a burocracia sanitária, elementos constitutivos da estrutura social capitalista. Não se tratava apenas de organizar o âmbito da saúde pública pa 
ra coagir as "classes populares", mas também de oferecer às outras classes as representações e, mesmo, os mecanismos de controle social.

Ao buscar esta ārea de administração estatal, prọ curou-se-ā, tambēm, a formação de intelectuais para o exercí cio das funções, destacando-se o papel dos Institutos Oswaldo Cruz (RJ) e Higiene (SP).

E, na sua contribuição para constituição de relạ ções políticas, das idéias sanitārias, de sua organização mais do que no controle de doenças, que a Saúde pública se impõe. Em 1957, ALMEIDA (1957:211) dizia:

"Hoje, no Brasil, por incrível que pareça, ainda

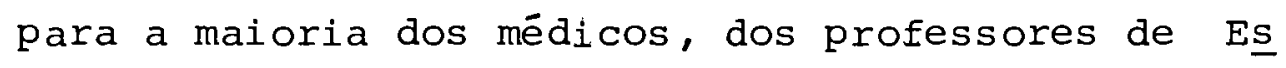
colas de Medicina e até de Escolas de Saūde Pūblica, saúde pública significa, apenas, fiscalização sanitária, quarentena, isolamento, comando sanitą rio, e por isso também assim pensam os leigos e a imprensa."

ressaltando que, no controle de doenças, ela se mostrava ine ficaz :

"... da saúde pública, no seu conceito atual, que já erradicou as pestilências, dominou as epidemias, está controlando as endemias em muitos países e haverá de erradicá-las, que reduziu a mortalidade, diminuiu a morbidade e a invalidez, que recupera a saưde, que duplicou a vida média do homem em pou cas décadas, nos países mais adiantados. Desta 
saúde pública que, infelizmente, meus senhores, o interior do Brasil ainda desconhece a não ser em poucas āreas privilegiadas." (ALMEIDA, 1957:208)

Contudo, é esta a Saúde Pública que se impõe. Até hoje predominam o efeito e os mecanismos destas ações coleti vas que, não só nos paises centrais, como no Brasil, conseguiram controlar algumas doenças epidêmicas importantes do ponto de vista do capital, no final do século passado e no início deste, e considerada como uma "revolução da saūde pú blica", como assinala TESH.(1982).

Se, como afirma a mesma autora, o Public Health Act não é uma vitória médica e sim de classes, a mesma afi $\underline{r}$ mação se aplica às Campanhas Sanitárias.

Os conflitos internos entre as diferentes frações da classes no início da República, prolongam-se, na década de 20, agudizados pela Primeira Guerra Mundial. Associados aos debates sobre a organização político-social entre republicanos, as oligarquias regionais não hegemônicas, os anarquistas e, posteriormente os comunistas, as reformas dos ser viços de Saúde Pública ocupam o centro de atenção e de debā tes. Nestes debates, como mostra LABRA (1985), não só se identificam forças divergentes, envolvendo representantes de entidades médicas, Sociedade de Medicina e Cirurgia, e órgãos oficiais, como também, está incluída a questão da autonomia das administrações locais, como bem mostrou o protesto da Sociedade de Medicina e Cirurgia da Bahia, em relação às ações da Diretoria Geral de Saủde.

A descentralização republicana é meramente executí 
va, uma vez que os recursos orçamentários, provenientes de taxas de importação, de selo e de consumo, estabelecidos pe la Constituição de 1891, beneficiaram apenas os estados economicamente mais poderosos, como nota FAUSTO (s/d). Conseqlientemente, grande parte dos estados dependia do governo fe deral, não se concretizando os ideais republicanos de autonomia estatal.

Uma maior interferência do governo federal encontra rá maior aceitação após 1920, em virtude da crise econômica cafeeira desde o início do século e agravada com a primeira guerra mundial. E a partir desta data que se inicia, segundo GOMES (1982a:151) "... ○ longo processo pelo qual a po breza começa a ser identificada como incômoda e até perigosa e associa à valorização do trabalho e a uma esfera de maior atuação no Estado no mercado de trabalho ..."

O liberalismo, de que se serviram os independentes para libertar-se de Portugal, "... sempre foi sensivel às pressões dos interesses privados pelo aumento da capacidade regulamentadora do poder público" (GOMES, 1982a:152). E ao longo do tempo, "o abandono do liberalismo é comprovado pela política imigratória tarifária e no início do século, de vạ lorização do café."

Contudo, as idéias liberais deveriam ser ajustadas às condições específicas do desenvolvimento econômico tardio do Brasil, alēm das condições internacionais que marcam este

(8) $\bar{E}$, também, nessa década que se delineia a fragmentação de uma políti ca social dirigida aos trabalhadores em geral e aos trabalhadores ur banos ativos, via previdência social. Sobre a previdência social nó Brasi1, v. MALLOY (1976, 1986); COHN (1980); TEIXEIRA (1980); BRAGA \& PAULA (1981). 
período (Primeira Guerra Mundial, a Revolução Russa, os movi mentos nacionalistas da França).

Assiste-se, na década de 1920, como também no pe ríodo de 1934 a 1937, à crítica ao liberalismo representado pela República, que pretendia "construir o progresso sem co gitar do homem em sua dimensão espiritual e subjetiva" (daí a importância da educação) e ao liberalismo internacional que não atentava para as especificidades nacionais, não integran do o homem à sua terra, a sua gente ..." (GOMES, 1982b:113) Em 1922, assiste-se a uma série de movimentos sócio-culturais (o tenentismo, a semana de arte moderna) que procurarão valo rizar aspectos nacionais.

As crises econômicas, as greves, os movimentos so ciais são vistos como resultantes deste regime liberal-repu blicano, onde havia um território e um povo, mas não havia um governo. Na realidade, os conflitos políticos das oligar quias regionais, com predomínio dos Estados mais ricos no aparelho estatal, contrastavam com uma organização política de caráter nacional. Como assinala CUNHA (1963:16) a "... nação é entendida como um equilíbrio ou armistício entre gru pos locais de poder. O poder desses grupos, reconhecido na Monarquia, amplia-se na República a ponto de livremente con trairem os Estados empréstimos no estrangeiro, de cobrarem impostos e manterem suas próprias Forças Armadas. As instituições político-governamentais nacionais são, não raro, sim ples emanações dos poderes estaduais." A revolução de 30 quebrará essa oligarquia num dos seus sustentáculos o café, criando o Departamento Nacional do Café, com poder suficien 
te para se impor a todos estados produtores, garantindo ao regime com essa intervenção o apoio das oligarquias regionais mais pobres.

Por outro lado, os movimentos grevistas marcam a presença reivindicatória das classes trabalhadoras urbanas, tornando necessária a tentativa de harmonizar a relação capi tal/trabalho.

O liberalismo, voltado para ideais vagos e doutrinários, não resolvera os problemas centrais do país e, as propostas apresentadas por diferentes movimentos sócio-cultụ rais, representavam para alguns "fantasias teóricas", como assinala o Deputado Gama Rodrigues, citado por MASCARENHAS (1949:94) na defesa de sua oposição à Reforma Sanitária Estą dual de 1925:

"O fim é fazer a educação sanitária do povo ... Na minha fraca opinião, é uma dessas fantasias teóricas que se podem aproximar daquilo que, em tempo, foram as repúblicas escolares de triste e ridícula memōria ..."

A grande questão, a partir da década de 20 , era or ganizar o mercado de trabalho, valorizando o trabalho para a continuidade da ordem e do progresso e, conseqtentemente, com batendo os distúrbios, como a pobreza e a doença. É, dentro deste quadro geral, que à Saúde Pública caberá um novo papel. Se até 1925, e assim o demonstram as reformas e a estrutura administrativa do Serviço Sanitário de 1891, 1896, 1906, 1911 e 1918, predominavam na organização institucional os serví ços laboratoriais, e os hospitais de isolamento e de doentes 
mentais (v. MASCARENHAS, 1949) que eram bases fundamentais no controle de doenças específicas, a partir da década de 20 , - Serviço Sanitário começa a ampliar suas atividades, com a proteção à infância, a inspeção de amas de leite e a profila xia geral.

E, embora incorporando as Campanhas Sanitárias co mo seu método de ação fundamental, a saúde Pública buscará, como todo regime político da época, novo mecanismo de contro le social - a educação - integrando valores liberais de cons tituição do Estado burguês, que se inicia após a década de 20, "quando o governo passa a sobrepor-se à ordem estabelecí da pelos senhores rurais, impondo uma ordem pública, seja em matéria de polícia, seja de educação, saúde pública e comuni cação ..." (CUNHA, 1963:35)

Contudo, se a educação nos países capitalistas cen trais representava um valor liberal para a prática da cidada nia, da democracia, no Brasil, ela servirá de base para a construção do trabalhador dentro de "democracia" social, num regime ditatorial corporativista, como se verá posteriormente.

E não é sem razão que MASCAREnHAs (1949:117) assinala que a reforma de 1931 consiste num retrocesso com rela ção a 1925 e que representa "... reflexos de duas escolas com pontos de vista diferentes." A reforma de 1925 resultava de "... três anos de estudos, recebendo influência das discussões prolongadas durante meses, na Câmara de Deputados e Senado estaduais, o Decreto no 4891, de 13 de fevereiro de 1931, foi elaborado sem discussões püblicas, saindo abrupta- 
mente, conhecido apenas pelas autoridades sanitárias que o elaboraram, do Secretário do Interior e do Interventor Fede ral que quiçá nada mais fez do que apôr sua assinatura no mesmo ..."

Mas é pelo Código Sanitário de 1918 e pela Reforma de 1925, que a Saúde Pública cria e impõe sua área de atuaÇão e sua autoridade no aparelho estatal. E a partir de en tão, incorporará, além do controle das doenças transmissí veis, a higiene do trabalho, do alimento, do escolar, a le pra, a fiscalização domiciliar, da medicina e farmácia, am pliando, ainda mais, nas reformas de 1931 e 1938, para in cluir a tuberculose, a sífilis e doenças venéreas, assistência dentária e a febre amarela. Neste momento, demarca-se, com maior nitidez, o público e o privado, a saúde pública e a assistência médica privada de carăter liberal, liberalismo, diga-se de passagem incipiente, ligada ao setor püblico, através dos auxílios e subvenções estatais que manterá a maioria dos serviços médico-hospitalares, com o caráter fí lantrópico, dominantesna época e onde se desenvolve grande parte da atividade da medicina liberal.

A reforma de 1925 reflete os conflitos divergentes existentes quanto à organização social e, inclusive, sanitária e ela receberā críticas "... de uma corrente que se obs tinava em não transformar a rotina dos serviços de saúde pú blica do Estado ...", corrente esta cujo porta-voz era o De putado Gama Rodrigues. "... ilustre clínico de grande nomeada região do Vale do Paraíba ..." (MASCARENHAS, 1949:94). Fenômeno que se reprođuz, também, no Rio de Janeiro, em tor no da Reforma de 1924, participando da discussão elementos da 
Sociedade de Medicina e Cirurgia do Rio de Janeiro, a Acade mia Nacional de Ciência, e dos órgãos públicos, como demons tra LABRA (1985).

A originalidade desta reforma estadual estā na in trodução de Inspetoria de Educação Sanitária e de centros de Saúde e da Inspetoria de Higiene dos Municípios, suprimindo as Delegacias de Saúde. A primeira incumbiria de "... promo ver a formação de uma consciência sanitária da população em geral e dos serviços de profilaxia geral e específica ..." (MASCARENHAS, 1949:92) e seria constituída de 5 centros de Saúde, na Capital, ficando os postos de higiene municipais responsāveis por aquela ação, no interior. Como assinala o mesmo autor, essas unidades teriam "... caráter essencialmen te de assistência sanitäria e estranho, conseqủentemente, a toda clínica que não tiver o objetivo profilático ..." (:92)

Pela reforma, caberia à Inspetoria de Higiene dos Municípios, "... promover a salubridade pública, de modo a abranger todos os problemas sanitários que interessarem a es ta circunscrição; organizar e executar com estes objetivos serviços locais de higiene a expensas do Estado e do respectivo município; nos termos do decreto o serviço de higiene ora previsto, instalado no município, desligará o município da delegacia de saúde da respectiva zona ..." (MASCARENHAS, 1949:96). Portanto, previa-se uma maior autonomia local. Se gundo o mesmo autor, na administração Paula Souza (1922 a 1925), "... só existiam no interior, alēm das delegacias de saúde, postos não permanentes de combate intensivo ao tracoma, à verminose e à malária. o serviço sanitário começou a 
instalar ... postos de higiene de caráter permanente. Segun do relatório desse Diretor Geral, referente ao ano de 1922 ... a Rockfeller Foundation entrou em acordo com o Governodo Estado para auxiliar a instalação de postos de higiene perma nente, estes postos deveriam ser em número de nove em 1924 e, paulatinamente, deveria atingir, até 1928, vinte e um pos tos. Esta instituição norte-americana auxiliaria financeira mente na organização destes postos municipais, contribuindo com 53\% das despesas de cada posto no primeiro ano; em cada ano essa contribuição iria diminuindo, até atingir a $10 \%$ no ültimo ano ..." (MASCARENHAS, 1949:97)

Porém, o grande mérito da Reforma de 1925 é que ela procurará construir no aparelho estatal o espaço da burocra cia sanitäria (9) inclusive a formação de quadros, tendo o centro de saúde e a educação sanitária como eixo central de um processo de descentralização e sob influência de princípios liberais. Nesta construção, a saúde Pública não abandona mas adere a idéia de polícia sanitária, no sentido ori ginal do termo grego"politeia", "constituição ou administra ção do Estado" (ROSEN, 1980:148). Como observa o mesmo autor, a administração pública, ramo da ciência da polícia, "...forneceu a base a partir da qual o conceito de polícia mé dica pode se desenvolver ..." (ROSEN, 1980:151) e significava um programa de ação voltada à saūde que visava mais um au mento de poder do que melhoria de condições de vida da popu lação.

(9) Na defesa da Reforma de 25, "o senador Reynaldo Porchat, entre outras coisas alegou: a reforma foi idealizada por técnicos de reconhe cido valor ..." (MASCARENHAS, 1949:94). 
Contudo, dadas às circunstâncias brasileiras, esta polícia sanitária não deveria ter o caráter policialesco e fiscalizador do Império, mas um caráter educativo, dentro dos princípios liberais vigentes ou seja, impor-se pela per suassão.

A influência de princípios liberais decorre, inter namente da República, reforçados pela formação exterior de grande parte desta burocracia sanitária. Assim como, a par tir da República, a burocracia militar passa a ser treinada em centros europeus (Alemanha, França), a burocracia sanitá ria do Estado de São Paulo, em constituição, receberá seu treinamento basicamente sob influência americana desde seus primórdios e tendo seu espaço institucional limitado dentro da Faculdade de Medicina, buscará então através da criação de Instituto de Higiene, sua autonomia. Em 1918, o governo estadual estabelece convênio com a Fundação Rockfeller para ministrar cursos de higiene aos estudantes de medicina em moldes modernos, sendo enviados para cá dois sanitaristas, Darling e smillie. O primeiro foi chefe dos Laboratórios da Missão Gorgas no Panamá, Maláia e zonas tropicais, tendo si do diretor do Laboratōrio de Higiene, de 1918 a 1920 . O con vênio possibilitou a criação deste laboratório, subordinado à cadeira de Higiene da Faculdade de Medicina e, em 1924, transforma-se em Instituto de Higiene.

No mesmo ano, 1918, indicados pelo International Health Board of the Rockfeller Foundation, fazem parte da primeira turma da Johns Hopkins school of Higiene and Public Health (proposta e subvencionada por aquela Fundação) os Drs. 
Francisco Borges Vieira e Geraldo Paula Souza que "... were brought from São Paulo, Brazil, where the International Health Board was intending to open a school of public health for Latin America; they were to be two of the first faculty of the Brazilian School." (FEE, 1987:76) Em 1927, Paula Souza e Borges Pereira escrevem ao Dr. Strode, solicitando auxílio da Fundação Rockfeller para defender a autonomia do Instituto. E, em 1930, Paula Souza sugere a transformação do Insti tuto em organização internacional (10).

Na aprovação da Reforma de 1925, "o Legislativo re duziu o número de Centros de Saúde de 5 para 1 permanecendo apenas o Centro de Saúde Modelo. Pretendendo economia, au mentou de 11 para 42 o nümero de funcionários solicitados pạ ra o Centro de Saúde Modelo:" (MASCAREnHAS, 1949:95). Propos tos na República, os centros de Saúde serão implantados no Estado Novo.

3. A INSTITUCIONALIZAÇÃ̃O DA SAÚdE PÚBLICA: A RACIONALIDADE TÉCNICA (1930 - 1945)

Os anos 30 marcam a perda de hegemonia da burgue sia cafeeira e a incapacidade das oligarquias regionais de assumir o poder. A crise mundial de 1929 afeta, profundamen te a burguesia cafeeira que neste mesmo ano, conta com umá grande produção agrícola. Estas crises econômicas, somadas aos conflitos entre a burguesia e outras frações, que já se

(10) Faculdade de Saúde Pública - USP - "Histórico do Instituto de Higiene" - (datilografado). 
desenvolviam nas décadas anteriores, se expressam nas eleições de 1930 (11)

Diante desta crise econômica e política, inaugurase uma nova etapa da sociedade brasileira, que se caracterizará pela centralização do poder, que passa a ser o árbitro dos diferentes interesses e como tal, o governo federal am pliará sua área de atuação e controle, inclusive na área de s aúde.

Como mostra GOMES (1982b:120), "a construção do projeto ideológico do Estado Novo evidencia que a busca de legitimação da autoridade se dá de uma forma e por motivos completamente distintos daqueles que fundaram a legitimidade dos regimes anteriores. A competência da autoridade reside exatamente no abandono dos problemas políticos e no fato de se concentrar em uma série de objetivos englobados e defini dos como medidas responsáveis pelo bem estar social. A ques tão social assume a dimensão simbólica de emanação dos males brasileiros e a bandeira identificadora do cerne do projeto político-ideológico do Estado Novo."

A República perdera sua legitimidade ao ignorar as massas, cabendo ao novo regime integrá-las, dentro de precei tos liberais, a um novo ideal não de democracia política mas de justiça social.

Como nota GOMES (1982b:126) "a nova democracia tí nha o ser humano como alvo de suas preocupações não desejan-

(11) São por estas características deste momento de crise de hegemonia, em que nenhuma fração da classe burguesa consegue domínio político e a classe trabalhadora encontra-se ainda em constituição, que alguns autores assinalavam a revolução de 30 como uma "revolução por alto" ou bonapartista. 
do nem sua desintegração como ocorria no liberalismo nem a sua estatização, como ocorria no totalitarismo." Ao regime cabia uma forma de integração, divergente dessas experiências e essa integração dar-se-ia pelo trabalho, como valorização do homem.

"Pelo trabalho o homem conquista a prosperidade eco nômica, a cultural intelectual, o respeito e a proteção do Estado. A ordem política se destina a assegurar a paz, a concórdia, o bem estar, a felicidade dos que trabalham pelo bem comum ... O trabalho - outrora forma de escravidão - é hoje um meio de emancipação da personalidade ... Viver ho nestamente do trabalho é o maior dever do cidadão e sua mais alta virtude, no Estado Moderno... " assim afirma Andrade, um dos ideólogos do Estado Novo (apud GOMES, 1982b:126, 127).

A "democracia" a ser implantada não era para pre servar a liberdade política mas, distribuir a justiça social. "... O que há de eterno no ideal democrático é esta aspiração de justiça social. Mesmo o problema da liberdade, exagerado pelos filósofos do liberalismo, passava a segundo plano diante do problema da justiça: "... pois a liberdade só se legitima quando é justa ... o problema fundamental é o obter justiça melhor e mais perfeita do que a que tem sido ministrada e não de conquistar uma liberdade que jā lhe foi concedida pela graça da lei, inspirada na doutrina liberal ..." (Andrade, apud GOMES, 1982b:129, 130).

Neste sentido, o próprio sentido de política passa a ser revista e o Estado passa a se constituir "... no que deve ser: uma técnica de construção do povo ...", que, como 
nota CUNHA (1963:6) "... precisamente quando o Estado assu miu feições mais marcantes do exercício de poder, a administração pública passou a ser entendida como técnica, ou que toda ação do Estado se pudesse exercer através de uma organi zação de caráter técnico ...".

CAMPELLO DE SOUZA (1983:84) mostra os mecanismos de centralização utilizados, a partir de 1930, com a "progressiva ocupação do espaço organizacional e decisório das agências burocrātico-estatais ...", das quais o Departamento Nacional de Saúde - D.N.S. - é um deles. A ocupação do espa ço é demonstrada pela Constituição de 1934, que inclui "... um capítulo especial sobre os funcionários públicos, enumeran do todos os princípios e normas que lhe dizem respeito, inclusive a votação de um Estatuto do Funcionalismo Público (1934), estabelecendo os princípios de organização da função pública ..." (RODEE et alii, 1959:323).

CAMPELLO DE SOUZA (1983:85) observa que "... sem qualquer modificação radical na estrutura sócio-econômica en caixavam-se no sistema político novos grupos e interesses, devidamente captados e burocratizados;... a implantação de Estado centralizado e forte significou ... uma redefinição dos canais de acesso e influência para articulação de todos os interesses velhos e novos com poder central ..."

o novo regime busca a unificação, intervindo nos estados, implantando rede de órgãos burocráticos, via inter ventorias e DASP (Departamento Administrativo do Serviço Pú blico), ambos sujeitos ao Presidente da República.

Este último substitui o Conselho Federal de Servi- 
Ço Público, em 1937 e como nota GRAHAM (1968:4) resulta do modelo americano:

"For some thirty five years Brazilian leaders in the public administration field have been trying to initiate fundamental change in their nation's administrative system by imposing concepts and techniques borrowed from American experience. They have attented to create a "modern" public personnel system wich will replace favoritism and patronage with rational recruitment practices and they have devoted considerable time and effort toward putting into practice ideas and techniques from the economy and efficiency movement in the United States ...",

influência esta assinalada, tambēm, por CUNHA (1963).Este mes mo autor mostra que o DASP, instalado em 1938, centralizou a reforma administrativa, tendo poderes para elaborar o orça mento dos órgãos públicos e o controle contábil da execução orçamentária. A multiplicação dos novos aparelhos burocrátí cos, encarregados de reformar as atividades de educação, sậ de e agrícola, acentuou sua importāncia na montagem de uma estrutura de poder e a possibilidade de absorver as novas for ças sociais surgidas nas décadas de 20 e 30 (as classes médias urbanas, o proletariado).

CAMPELLO DE SOUZA $(1983: 88)$ ressalta que "... em São Paulo e no Rio Grande do Sul, estados política e cultural mente mais complexos e resistentes à sujeição do centro e que, além disso possuiam fortes milicias estaduais, o gover- 
no federal viu-se obrigado a estabelecer um sistema de rodí zio de interventores, provavelmente em virtude de tensões que este mecanismo ocasionava, e também, para evitar um rápido encastelamento das novas máquinas políticas ...", ou também, em decorrência dos conflitos de interesses, que marcam o pe ríodo de 1930 a 1938 (Revolução Constitucionalista, Constitui ção de 1934, formação do Partido Integralista).

Consequlentemente, este sistema de rodízio repercu tia nos órgãos estatais, obstando qualquer tentativa de orga nização mais autônoma em relação ao poder central. Uma das dificuldades, na organização sanitária, que se segue à ges tão de quatorze anos de Emílio Ribas, foi a troca dos respon sáveis:

"... a permanência média, no período anterior a 24 de outubro de 1930, foi maior, sendo 740 dias. A média para nomeados entre 20 de outubro de 1930 a 26 de julho de 1948, foi de 203,81 dias..." (MASCARENHAS, $1949: 28$ )

A princípio, o sistema de interventoria, na ārea de saūde, parece ter sido mais direto, sem intermediação de quadros locais. BARROS BARRETO (1942) (12), ele próprio Delegado de Saúde, em São Paulo, em 1931, ao analisar a organi zação dos serviços de saúde nos Estados, mostra a ligação do Departamento Nacional de Saúde - D.N.S. - e as Delegacias

(12) Barros Barreto foi, em 1914, Diretor de Higiene do Estado do Rio de Janeiro; bolsista da Fundação Rockfeller, na Johns Hopkins Universi ty - Area de Higiene Industrial em 1924; assistente de Diretor Geral do Departamento Nacional de Saúde entre 1926 a 1929; Diretor do mesmo Departamento, entre 1935 a 1939 e 1941 a 1945 e Vice-Diretor da OPS, em 1942. (Arq. Hig., 1960; LABRA, 1985). 
Estaduais para o progressivo aprimoramento dos serviços locais sob bases uniformes.

$$
\begin{aligned}
& \text { "Hoje, Amazonas e Piauí têm médicos do D.N.s. na } \\
& \text { direção das suas repartições sanitārias, para as }
\end{aligned}
$$
do Acre e do Pará devem ir outros médicos ... Na Paraíba, aquele cargo de assistente do diretor foi preenchido por técnicos federais de 1935 a 1938. As sim, tambēm, vai se sucedendo em Pernambuco que, de 1931 a 1937, teve como diretor de saúde um sani tarista do D.N.S. ... Sergipe ... há um mês o cargo está ocupado por um técnico do D.N.S. porque assim o recomendou o Sr. Presidente da República... Em São Paulo, implantaram-se normas modernas, quando na superintendência dos serviços de saúde,o atual diretor geral do D.N.S. ... as mesmas diretrizes gerais, fixadas para outros Estados, inspiraram a reforma de 17 de junho de 1938 ..."(BARROS BARRETO, 1942:205).

Em 1939, em 13 Estados, os diretores de saúde ou assistentes de diretores eram técnicos do D.N.S. Em 1941, retoma-se a "... iniciativa de mesma estreita vinculação,que se vai assegurando pela mesma forma ou pela atuação eficiente das Delegacias Federais de Saúde."(BARROS BARRETO, 1942: 206)

A partir de 1930 e, dentro desta estratégia fede ral, a Saúde Pública ocupa um maior espaço institucional e, inclusive como assinala CUNHA (1963:50) "... por pressão dos intelectuais e militares na criação de novos serviços ... num 
período de dificuldades financeiras ... em que a administra ção federal não se propõe a grandes esforços de aprimoramento ..." Esta pressão resulta, em 1931, na criação do Ministério de Educação e Saúde e, em nível estadual, da Secretaria de Educação e Saúde Pública. Em 1935, esta é reorganizada e aquele em 1937, como resultado de "... um dos raros esforços do Legislativo para reformar a administração" (CUNHA, 1963:70), num período de intenso desgaste da organização constitucional, de desmoralização do congresso pelas classes dominantes, divididas entre interesses econômicos di vergentes dos grupos agrícolas, grupos financeiros e comer ciais, como mostra o mesmo autor.

RODRIGUES (1967:28) nota que "... inegavelmente, a Constituição de 1934, entre todas as outras dispensou especial carinho à Saúde pública dando-lhe a devida importância como responsabilidade de governo ... Mais duas constitui Ções vieram a reger os destinos do nosso país depois de pro mulgada em 1934 mas, em nenhuma delas, nem mesmo na atual com suas reformas, vamos encontrar estabelecidos tão amplos cuidados com a saúde pública do país ... A Constituição de 1946, inexplicadamente continua bastante suscinta no que se refere à Saúde Pública ... A própria organização de combate às endemias rurais, que na Constituição de 1934, se destacava como artigo especial, ficou englobada com outros problemas..."

Contudo, a Saúde Pública procurará sedimentar sua ampla área de atuação e neste processo, provavelmente, a bu rocracia sanitária como parcela da burocracia pública compos ta por frações da classe média e outras frações será extrema 
mente beneficiada, em virtude de sua larga adesão a Resolu u ção Constitucionalista de 32, como nota CUNHA (1963:53).

"... Nunca o funcionalismo público granjeou tantas simpatias, o que explica porque, no final desta ar rancada contra-revolucionária ou seja, na Constitui ção de 1934, seja ele especialmente beneficiado..."

A nova estrutura da Secretaria de Saúde, surgida após o Estado Novo, teve pouca duração, incluindo novas fun ções como a fiscalização do leite e laticínios, a higiene e assistência dentária, profilaxia de impaludismo e defesa contra febre amarela.

Mas, se a partir de 30, a saúde Pública assume maior peso institucional com proliferação de unidades, como se verá, outras āreas tambérn o fazem, correspondendo a uma ampliação da esfera governamental, e a incorporação de novos interesses, além daqueles da burocracia sanitária, resultante de uma maior divisão social do trabalho.

Assim nem bem constituído, do Departamento de Saū de, tanto em nível federal como estadual, desmembram-se algu mas áreas que lhe eram especificas, como nota RODRIGUES (1967: $114,115)$.

\footnotetext{
"Instituia-se, então, a uniformidade de ação, en globando todas as atividades que, direta ou indire tamente tinham influência na prevenção, manutenção ou recuperação da saūde do povo. o Departamento Nacional de Saúde Pública iria, durante anos, exe $\underline{\underline{ }}$ cer sua ação normativa e executiva, até começarem
} 
a ser desintegradas do seu bojo atividades que por direito deveriam continuar na sua alçada ... Sur preendente é observar o paradoxo de terem sido des membradas as atividades de saúde pública da organi zação onde estavam entrosadas, espalhando-as por vārias Secretarias de Estado da administração fedẹ ral, exatamente quando a Saúde Pública, até então, subordinada ao Ministério da Justiça, passava com a Educação, a ter Secretaria própria."

Esta fragmentação de órg̣ãos, ligados à problemátí ca de saúde pública, representa, contudo, um aumento de me diação estrutural e que obscurece, ainda mais, os determinan tes das condições de saúde.

Essas mediações, entretanto, tornam-se necessārias do ponto de vista político, servindo para abrigar os diferen tes interesses na área de saúde, não só da burocracia pública na sua tentativa de progressiva ocupação do espaço organi zacional e, em consequência de maior autoridade e de recur sos, como também, dos interesses privados, devidamente articulados a ela e que resultam das novas condições sócio-econô micas brasileiras.

Ao mesmo tempo em que se assiste a uma fragmentação dos órgãos originalmente da saúde Pública, tem-se, na própria Secretaria, a concentração de alguns departamentos jun to à autoridade máxima, o secretario. Assim se, na estrutura de 1938, todas atividades referentes à saúde pública con centram-se no Departamento de Saúde, (Organograma 1), em 1943, parte dessas atividades passa a subordinar-se àireta 
mente ao Secretário e especificamente a Saúde Mental, a Medi cina Social, o Instituto Butantã e o Departamento de Profila xia de Lepra e a Repartição de Transportes, (Organograma incorporando-se, a partir de 1948, o Departamento Estadual da Criança, demonstrando que algumas atividades, embora tẹ nicamente justificada sua subordinação à burocracia sanitā ria, saem do seu âmbito de autoridade legítima para, provavel mente, servir a interesses politicos, destruindo a pretensa racionalidade técnica.

A destruição desta racionalidade técnica encontra fundamento na sua própria constituição dentro do aparelho de Estado, que ao abrigar interesses diferentes, conflituosos põe em jogo a própria legitimidade da burocracia, como ór gão técnico.

Uma análise histórica da incorporação de problemas, que constituirão áreas tradicionais de Saúde Pública, mostra a relação do privado/público e como o aparelho estatal vai incorporando-os, desenvolvendo atividades, destinando-lhes re cursos iniciais e estruturando-se em organizações burocráti cas mais complexas.

Como já foi assinalado anteriormente, a tuberculo se, a lepra e a mortalidade infantil já aparecem no cenário nacional como fenômenos relevantes no século anterior, fican do a responsabilidade de seu controle basicamente para san tas Casas.

Ao adquirirem maior transparência com as aglomera ções urbanas, dão origem a movimentos civis, que congregam médicos e leigos, basicamente, mulheres que se dedicam à $f_{\underline{i}}$ 
ORGANOGRAMA 1 - Secretaria de Educação e Saúde, 17 de junho de 1938.

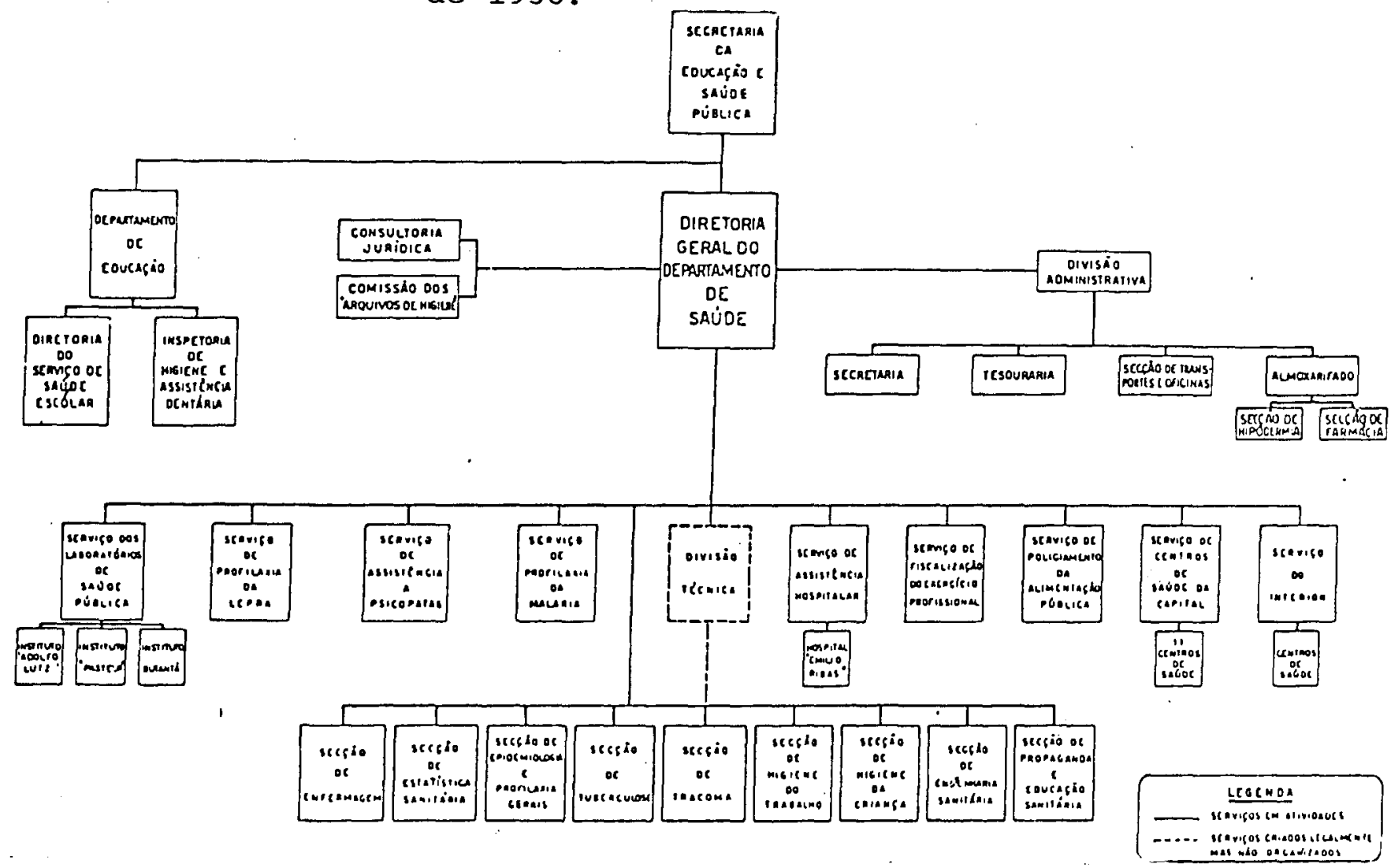

ORGANOGRAMA 2 - Secretaria de Educação e Saúde, 31 de dezem bro de 1943.
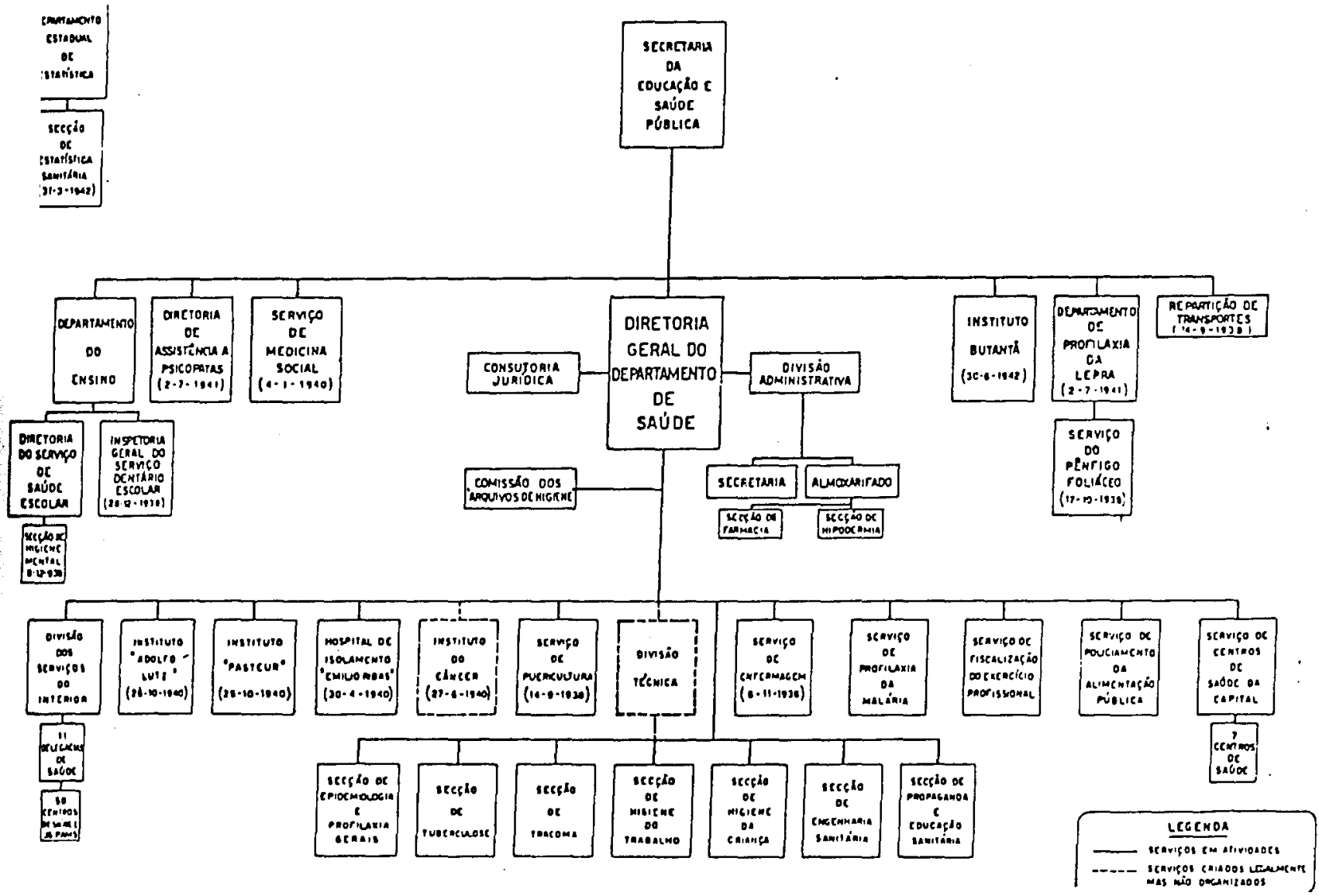

FONTE: MASCARENHAS (1949) 
lantropia, em associaçōes ou ligas. Estas ligas (contra le pra, contra tuberculose, de proteção à infância), servindose da divulgação e propaganda, arrecadam recursos da popula ção em geral ou criam taxas de contribuição, buscam auxílios governamentais fundando sanatórios, leprosários ou casas de proteção aos órfãos.

Observa-se que a estratégia utilizada, seja no Bra sil ou no exterior, é a mesma.

WAKSMAN (1964:112, 113) descreve que "...numerosos grupos de médicos e leigos, em vários países, organizaram as sociações para prevenção da consunção e de outras formas de tuberculose. Uma das sociedades foifundada em Londres, em 1898. Seu objetivo era divulgar para o grande público a na tureza contagiosa e as medidas sanitárias e de prevenção que deveriam ser adotadas. Em 1904, havia 38 sociedades desse gēnero, nos Estados Unidos e nesse mesmo ano, a "National Association for the Study and Prevention of Tuberculosis" foi organizada. Uma campanha para venda de selos especiais na época do natal foi iniciada por um funcionário postal da Dinamarca e foi levada a efeito nos Estados Unidos. A ini ciativa permitiu enfrentar alguns problemas financeiros da novel Associação ..."

No Brasil, a origem de ligas remonta ao período im perial, quando são fundadas inúmeras obras filantrópicas de cuidado às crianças órfãs, leprosos, alienados, doentes e in válidos pelas elites paulistanas e pela Igreja, como mostra SPOSATI (1987), cujos resquícios persistem na República, o que não é raro na transição de um regime para outro. Em ge 
ral, como é demonstrado pela autora acima, nestas associaçōes, sempre havia um representante governamental ou era pre sidida pelo próprio governador da Província.

Em 1929, a Associação de Socorro aos tuberculosos, que lança o selo da Tuberculose, é presidida pela Sra. Cle mentino Fraga, diretor do Departamento Nacional de Saúde. Em 1933, a Secretaria de Educação e Saúde cria e regulamenta "... uma Comissão de Assistência Social do Estado composta de senhoras e cavalheiros sob a presidência do Diretor Geral do Serviço Sanitário ..." (MASCAREnHAs, 1949:129)

Existe, portanto, uma ligação entre as entidades civis e o aparelho de Estado que, num primeiro momento, exer ce certo controle através da notificação e da fiscalização dos problemas levantados. A possibilidade de obtenção de re cursos, necessários à sua existência, faz com que a burocracia estatal incorpore, paulatinamente, o controle geral.

A lepra, tornada de notificação compulsória em 1911, é assumida pelo governo estadual, em 1917, através de um acordo com a Santa Casa para sua profilaxia geral. Em 1925, é criada a Inspetoria de Profilaxia de Lepra cujas fun çôes eram:

$$
\begin{aligned}
& \text { "I - estudo da infecção; } \\
& \text { II - promover no Estado a profilaxia da mesma; } \\
& \text { III - fiscalizar todos os serviços que se organí } \\
& \quad \text { zarem com o mesmo fim profilātico; } \\
& \text { IV - } \text { organizar plano de construção de colōnias e } \\
& \text { outros estabelecimentos de leprosos, a car } \\
& \text { go do Estado e verificar os que forem orga- }
\end{aligned}
$$


nizados por municípios ou particulares, a fim de autorizar a execução quando os pla nos convierem e forem adequados as localizações destes estabelecimentos, que funcionarão sob a fiscalização e orientação técni ca do serviço estadual ora instituido." (MASCARENHAS, $1949: 96$ )

Nota-se, ainda, que o decreto previa apenas trēs cargos e a lei estabeleceu vinte e sete e sofreu criticas do Deputado Gama Rodrigues:

"A lepra está na moda, precisa de uma inspetoria especial ... Mas nada também me convencerá, senhor presidente, de que não seja por exemplo necessária nessa mesma ordem de idéias, uma inspetoria de pro filaxia de tuberculose, não sei qual delas levará vantagem, no que diz respeito à sua assolação en tre os habitantes do Estado." (MASCARENHAS, 1949:96) o que se pode deduzir é que, a partir de determina do momento, torna-se altamente dispendioso para entidades $\mathrm{f}_{\underline{i}}$ lantrópicas assumir o controle da doença como a lepra, neces sitando sua incorporação como uma atividade estatal. Esta permite a obtenção de maiores recursos do que as contribui ções ou taxas. A Lei no 2169 de dezembro de 1926 que estabe lece medidas destinadas à profilaxia de Lepra para constru ção de colônias, asilos e instalação de leprosários regio nais modelos, estabelece, também, a possibilidade de contrair empréstimos no valor de Cr\$10.000.000,00. A mesma lei determina a elevação ao dobro do imposto sobre consumo de 
aguardante "destinado o aumento de arrecadação para o servi ço de juros e amortização de empréstimo ..." (MASCARENHAS, 1949:105). Contudo, a parte da atividade é repassada a par ticulares, sob a justificativa de descentralização.

Em 16 de maio de 1931, a Lei é modificada pelo De creto no 5027 e permite a "... médicos clínicos, devidamente habilitados, examinar, tratar, em seus consultórios ou em do micilio, as pessoas atacadas por lepra que os procuram ...." (MASCARENHAS, 1949:124), justificada pela necessidade de des centralização de serviços. O mesmo decreto autoriza os hospitais gerais fundarem dispensários, cria subvenção aos sana tórios privados, autoriza Departamento de Saúde fundar cinco leprosários de emergência e para despesas, deposita, parcela damente, no Banco do Estado, à disposição do Inspetor Chefe até a quantidade de $\operatorname{Cr} \$ 2.000 .000,00 \ldots$...

Um fato relevante na captação de recursos é a crią ção de taxas sobre consumo. Na ausência de recursos orçamen tários ou como complementação, a proposta de criação e ou am pliação dos serviços de saúde vincula-se à cobrança de taxas sobre consumo. LABRA (1985:96, 97) assinala que, em 1918, na proposta visando o saneamento do Brasil e a criação de um Ministério de Saúde, o deputado federal e membro da Comissão de Saúde Pública na Câmara, Dr. Azevedo Sodré, sugere a cons tituição de um fundo com os seguintes recursos:

"a) taxa de 15 \& sobre produtos brutos dos jogos de azar em clubes, cassinos, etc., idéia essa ba seada na legislação francesa de 1907;

b) impostos de consumo de álcool ... exprimindo 
os anseios das elites brasileiras que, na épo ca, estavam engajadas na luta contra alcoolismo e que fazia parte dos paises industrializados para aumentar a produtividade dos operários e

c) o produto de venda de selo sanitário à semelhança do já criado na Argentina justamente pa ra obras sanitárias ..."

Em São Paulo, MASCAREnHAS (1949:129, 133) nota o mesmo fenômeno não só com relação à lepra, mas, com relação à assistência social. Os Decretos no 5797 de 11 de janeiro de 1933 e no 6297 de 07 de fevereiro de 1934 estabeleciam,res pectivamente:

"... impostos sobre determinados jogos e cassinos de praias de banho e estação de água ..." e "... contribuição especial a ser exigida nos fron tões de jogo de pela, em benefício da Comissão de Assistência Social. A quota mínima de cada fron tão era de $\operatorname{Cr} \$ 7.000,00$, sendo cobrada a base de Cr $\$ 0,40$ por "prole" premiada ..."

Em 1932, o governo estadual, sob intervenção fede ral, inclusive substituída por militares, em decorrência do movimento constitucionalista, libera o jogo nas estāncias bal neārias e decide aplicar recursos de sua tributação nas óbras assistenciais. A criação de taxas, como nota o mesmo autor (1949:212) "... sob os variados rótulos serviam para alguns diretores de órgãos de saúde pública ampliassem as atividades dos órgãos ..." 
E a partir de 1930, os serviços de saúde pública ampliam-se. A Tabela 4 mostra o número de estabelecimentos de serviços oficiais de Saúde Pública em 1945, segundo algu mas variáveis.

Observa-se que, do total de 1.008 estabelecimentos não hospitalares, criados entre 1918 a 1946 , apenas $18,5 \%$ correspondem ao nível federal, ficando 72,7 음 a encargo dos governos estaduais e $8,8 \%$ dos municipais. A grande expansão ocorre, no período de 1931 a 1946, dos 1.008 estabelecimentos, 50,68 foram instalados entre 1931/1940; 40,6응 no perío do posterior e apenas $11,6 \%$ entre 1918 a 1930.

Dos principais serviços criados, $71,2 \%$ referem-se a centros e postos de saúde e higiene sendo o restante, $28,8 \%$ de postos especiais, destacando-se os de combate à malária basicamente sob manutenção do governo federal, com a coopera ção da Fundação Rockfeller.

E a partir de 1938, quando se estabelece uma orga nização federal padrão (Organograma 3) para os serviços esta duais de saúde, que os centros de saúde passam a ser implantados como órgãos polivalentes e distritais, segundo BARROS BARRETO (1942), executando atividades de controle de doenças transmissíveis agudas, da tuberculose, lepra, doenças venéreas, a proteção médico-sanitāria da gestante e criança, o saneamento e polícia sanitāria das habitações, a higiene do trabalho e da alimentação e exames périódicos de saúde, des tinando-se para estes, no mínimo 5 médicos, 5 enfermeiras ou visitadoras. As unidades, que executavam as mesmas atividades em escala menor mas com menor número de pessoal, eram 
TABELA 4 - Estabelecimentos dos serviços oficiais de saúde pú blica, não incluídos na organização hospitalar,se gundo o ano de instalação, principais tipos de serviço e a entidade mantenedora, Brasil, 1946.

\begin{tabular}{|c|c|c|c|c|}
\hline \multirow{3}{*}{ Especificação } & \multicolumn{4}{|c|}{$\begin{array}{c}\text { Estabelecimentos Oficiais de Saúde } \\
\text { Püblica (1) }\end{array}$} \\
\hline & \multirow{2}{*}{ Total } & Segundo & Entidade & Mantenedora \\
\hline & & União & Estado & Município \\
\hline Total & 1.008 & 186 & 733 & 89 \\
\hline \multicolumn{5}{|l|}{ Segundo o ano de instalação } \\
\hline - De 1918 a 1920 & 8 & - & 8 & - \\
\hline - De 1921 a 1930 & 79 & 8 & 70 & 1 \\
\hline - De 1931 a 1940 & 512 & 39 & 411 & 62 \\
\hline - De 1941 a 1946 & 409 & 139 & 244 & 26 \\
\hline $\begin{array}{l}\text { Segundo os principais tipos } \\
\text { serviço-Centros e Postos }\end{array}$ & & 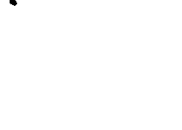 & & \\
\hline de Saüde e Higiene & 718 & 47 & 598 & 73 \\
\hline \multicolumn{5}{|l|}{ Postos especiais } \\
\hline De combate à malária & 140 & 110 & 28 & 2 \\
\hline $\begin{array}{l}\text { De proteção à maternidade e } \\
\text { infancia }\end{array}$ & 45 & 3 & 35 & 7 \\
\hline De combate às doenças tropicais & 39 & 10 & 25 & 4 \\
\hline De combate à lepra & 20 & 3 & 17 & - \\
\hline De combate ao tracoma & 11 & 2 & 9 & - \\
\hline Outros & 35 & 11 & 21 & 3 \\
\hline
\end{tabular}

NOTA: Embora os serviços oficiais de Saúde Püblica obedeçam, em linhas gerais, a normas uniformes quanto as suas funções de polícia sani täria e medicina preventiva, no que se refere a sua organização, há pê quenas variaçōes entre as diversas Unidades da Federação. Entretanto, na maior parte dos casos, os centros de saúde e postos de higiene,além de outras atividades, praticam a proteção à maternidade e à infáncia e o combate à tuberculose, à lepra, às doenças venéreas, etc.., independentemente da existencia de postos especiais para algumas dessas ativi dades.

(1) Abrangendo $97 \%$ dos serviços existentes.

FONTE: ANUÁRIO ESTATISTICO DO BRASIL (1950:445). 
ORGANOGRAMA 3 - Organização do Departamento de Saúde de um pequeno Estado

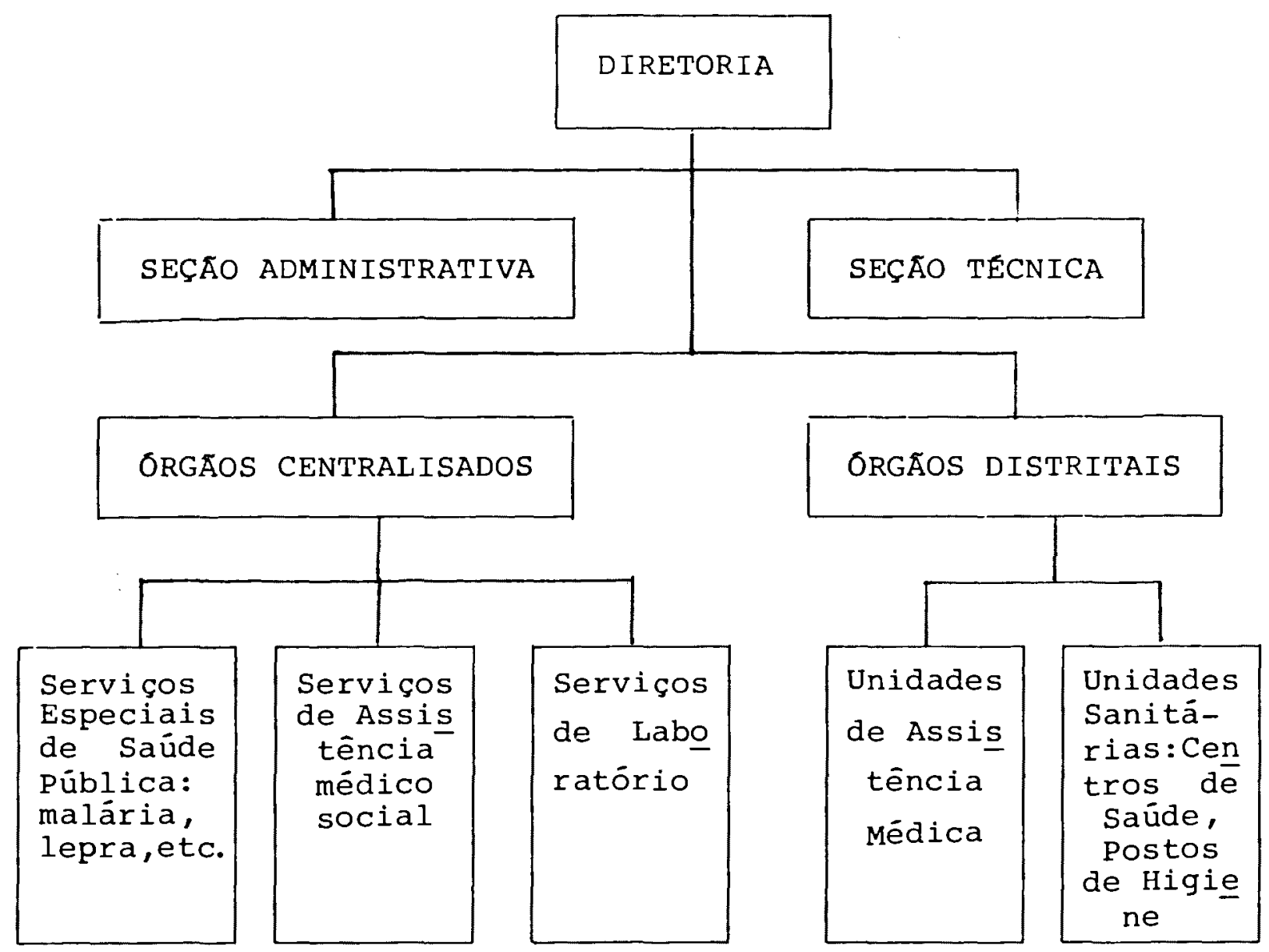

FONTE: BARROS BARRETO (1942:207).

classificadas como Postos de Higiene de primeira classe (P. H.1) e de segunda classe (P.H.2), este correspondendo como assinala o autor a "Country health unit" (médico, visitado ras, escrevente-microcopista, guarda ou inspetor sanitário, servente). A ausēncia de visitadora sanitária relegava o posto a categoria de sub-posto (S.P.). Os Postos especializados (PE) destinavam-se a uma atividade especifica (bouba, tracomal e os Postos Itinerantes (P.I.) móveis e independentes das unidades. 
A Tabela 5 mostra o número de unidades sanitárias existentes no Brasil, sendo são Paulo o Estado com maior nụu mero de unidades, principalmente de sub-postos e Distritos.

TABELA 5 - Unidades sanitárias existentes no Brasil, segundo categorias, segundo Estado, Território e Distrito Federal, 1941 .

\begin{tabular}{|c|c|c|c|c|c|c|c|}
\hline $\begin{array}{l}\text { Estados } \\
\text { Território } \\
\text { e Distrito } \\
\text { Federal }\end{array}$ & $\begin{array}{l}\text { No dos } \\
\text { Distritos } \\
\text { Sanitários }\end{array}$ & C.S. & P.H.1 & P.H. 2 & S.P. & P.E. & P.I. \\
\hline Acre & 7 & - & - & - & 7 & - & - \\
\hline Amazonas & 6 & 1 & - & - & 2 & - & - \\
\hline Parà & 7 & 2 & - & - & 7 & - & - \\
\hline Maranhão & 6 & 1 & - & 2 & 4 & - & 6 \\
\hline Piauí & 3 & 1 & - & 2 & 16 & - & - \\
\hline Cearā & 4 & 1 & 4 & 6 & - & 3 & 2 \\
\hline R.G. do Norte & 11 & 1 & - & 1 & 3 & - & - \\
\hline Paraiba & - & 1 & 1 & 6 & 10 & - & - \\
\hline Pernambuco & 10 & 4 & 2 & 13 & 32 & - & 4 \\
\hline Alagoas & 10 & 1 & - & 4 & - & - & - \\
\hline Sergipe & 7 & 1 & - & - & 6 & - & - \\
\hline Baía & 10 & 3 & - & 11 & 44 & 4 & - \\
\hline Espirito Santo & 7 & 1 & 1 & 5 & 1 & 2 & 1 \\
\hline Rio de Janeiro & 11 & 2 & 3 & - & 57 & - & - \\
\hline D. Federal & 15 & 15 & - & - & - & - & - \\
\hline São Paulo & 93 & 7 & 2 & 8 & 77 & - & - \\
\hline Paranā & 6 & 1 & 1 & 17 & 30 & - & - \\
\hline Santa Catarina & 7 & 1 & 4 & 2 & - & - & - \\
\hline R.G. do Su1 & 88 & 5 & 35 & 32 & - & - & - \\
\hline Minas Gerais & 26 & 1 & - & 25 & - & 4 & - \\
\hline Mato Grosso & 9 & 1 & - & - & 8 & - & - \\
\hline Goiàs & 7 & - & 1 & 6 & - & - & - \\
\hline T O T A L & 350 & 54 & 54 & 140 & 304 & 13 & 13 \\
\hline
\end{tabular}

FONTE: BARROS BARRETO (1942:209). 
MASCARENHAS (1949) assinala que, em 1932, algumas prefeituras e o governo estadual criaram algumas unidades sa nitārias, responsabilizando-se pela nomeação e pagamento de pessoal e que, em 1938, existiam 82 unidades sanitárias 10 cais, sem legislação alguma sobre elas, criadas graças ao es forço do Delegado e Inspector Geral do Interior.

Um fenōmeno bastante importante no Brasil é a expans o, também, neste período, dos serviços hospitalares, Tâ bela 6. Se, entre 1918 a 1930, existiam apenas 87 unidades de saúde pública (Tabela 4) e 705 unidades hospitalares,cres cendo as primeiras a partir de 1931, o mesmo fenōmeno verifí ca-se na rede hospitalar, principalmente, particular, que já detinha a maioria dos hospitais, 76,5\% de um total de 705 hospitais.

Observam-se alguns fatos importantes como a peque na participação dos estabelecimentos públicos, $392(23,3$ 잉, dos quais 44,4\% da União, 49,5\% dos Estados e 6,1\% dos Municípios. Dos 174 estabelecimentos instalados pela União, 86,8\% destinavam-se aos militares. Fato este compreensivel, dada a importāncia desta categoria no aparelho estatal e, na vida política brasileira, ocupando após 1930, algumas intervento rias.

O fortalecimento do executivo, na década de 30 e a consequente expansão da burocracia civil e militar, unificada em 1938, decorre da necessidade de sedimentação de uma he gemonia burguesa de cunho urbano-industrial. "De 1920 a 1940, - crescimento relativo da burocracia militar e civil é nada mais que quinze vezes superiores ao crescimento relativo da população ..." (CUNHA) 
TABELA 6 - Número de estabelecimentos da organização hospitalar, segundo a finalidade médico-social, entida de mantenedora e $\circ$ ano de instalação

\begin{tabular}{|c|c|c|c|c|c|c|c|c|}
\hline \multirow{3}{*}{$\begin{array}{l}\text { Ano de } \\
\text { Instalação }\end{array}$} & \multicolumn{8}{|c|}{ Es $t a b$ e 1 e c imentos } \\
\hline & \multirow[b]{2}{*}{ Total } & \multicolumn{7}{|c|}{ Segundo a finalidade médico-social } \\
\hline & & $\begin{array}{l}\text { Hosp. } \\
\text { Gerais }\end{array}$ & $\begin{array}{l}\text { Mater- } \\
\text { nidade }\end{array}$ & $\begin{array}{l}\text { P/Le- } \\
\text { prosos }\end{array}$ & $\begin{array}{l}\text { Doentes } \\
\text { mentais } \\
\text { e nerv. }\end{array}$ & $\begin{array}{l}\text { P/Tuber } \\
\text { culosos }\end{array}$ & $\begin{array}{l}\text { Outro } \\
\text { civis }\end{array}$ & $\begin{array}{l}\mathrm{P} / \mathrm{Mi} \\
1 \mathrm{it} .\end{array}$ \\
\hline \multicolumn{9}{|c|}{ U N $\mathbf{N} I \bar{A} \quad$} \\
\hline $\begin{array}{l}1900-1930 \\
1930-1946 \\
\text { TOTAL }\end{array}$ & $\begin{array}{r}85 \\
89 \\
174\end{array}$ & $\begin{array}{l}- \\
-\end{array}$ & $\begin{array}{l}2 \\
2 \\
4\end{array}$ & $\begin{array}{l}- \\
- \\
-\end{array}$ & $\begin{array}{l}3 \\
3 \\
6\end{array}$ & $\begin{array}{l}- \\
1 \\
1\end{array}$ & $\begin{array}{r}3 \\
9 \\
12\end{array}$ & $\begin{array}{r}77 \\
74 \\
151\end{array}$ \\
\hline \multicolumn{9}{|c|}{ E S T A D O } \\
\hline $\begin{array}{l}1900-1930 \\
1930-1946 \\
\text { TOTAL }\end{array}$ & $\begin{array}{r}78 \\
116 \\
194\end{array}$ & $\begin{array}{l}13 \\
27 \\
40\end{array}$ & $\begin{array}{r}3 \\
12 \\
15\end{array}$ & $\begin{array}{r}8 \\
22 \\
30\end{array}$ & $\begin{array}{l}14 \\
12 \\
26\end{array}$ & $\begin{array}{r}6 \\
18 \\
24\end{array}$ & $\begin{array}{l}21 \\
13 \\
34\end{array}$ & $\begin{array}{l}13 \\
12 \\
25\end{array}$ \\
\hline \multicolumn{9}{|c|}{ 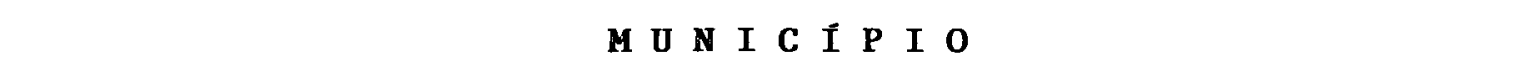 } \\
\hline $\begin{array}{l}1900-1930 \\
1930-1946 \\
\text { TOTAL }\end{array}$ & $\begin{array}{r}3 \\
21 \\
24\end{array}$ & $\begin{array}{r}- \\
12 \\
12\end{array}$ & $\begin{array}{l}- \\
1 \\
1\end{array}$ & $\begin{array}{l}- \\
- \\
-\end{array}$ & $\begin{array}{l}- \\
-\end{array}$ & $\begin{array}{l}1 \\
- \\
1\end{array}$ & $\begin{array}{l}2 \\
7 \\
9\end{array}$ & $\begin{array}{l}- \\
1 \\
1\end{array}$ \\
\hline \multicolumn{9}{|c|}{ P A R T T I C U L A R } \\
\hline $\begin{array}{l}1900-1930 \\
1930-1946 \\
\text { TOTAL }\end{array}$ & $\begin{array}{r}539 \\
750 \\
1289\end{array}$ & $\begin{array}{l}357 \\
280 \\
637\end{array}$ & $\begin{array}{l}24 \\
67 \\
91\end{array}$ & $\begin{array}{l}2 \\
4 \\
6\end{array}$ & $\begin{array}{l}20 \\
36 \\
56\end{array}$ & $\begin{array}{l}15 \\
45 \\
60\end{array}$ & $\begin{array}{l}121 \\
318 \\
439\end{array}$ & $\begin{array}{l}- \\
-\end{array}$ \\
\hline \multicolumn{9}{|c|}{$\mathbf{T} \bigcirc \mathbf{T A L}$} \\
\hline $\begin{array}{l}1900-1930 \\
1930-1946 \\
\text { TOTAL }\end{array}$ & $\begin{array}{r}705 \\
976 \\
1681\end{array}$ & $\begin{array}{l}370 \\
319 \\
689\end{array}$ & $\begin{array}{r}29 \\
82 \\
111\end{array}$ & $\begin{array}{l}10 \\
26 \\
36\end{array}$ & $\begin{array}{l}37 \\
51 \\
88\end{array}$ & $\begin{array}{l}22 \\
64 \\
86\end{array}$ & $\begin{array}{l}147 \\
347 \\
494\end{array}$ & $\begin{array}{r}90 \\
87 \\
177\end{array}$ \\
\hline
\end{tabular}

FONTE: ANUÁRIO ESTATÍSTICO DO BRASIL (1950:442).

O predomínio da assistência médica-hospitalar prí vada mostra o equívoco de alguns autores brasileiros que afirmam que esta se expande pós-64. Realmente, neste perío do, verifica-se uma nova expansão, cujo caráter mais empresarial corresponde às novas condições da sociedade brasilei- 
ra, contudo, a rede privada sempre foi dominante e privile giada pelos regimes governamentais.

Como tambēm parece equivocada a afirmação de um predomínio da Saúde Pública até 1960 para decrescer a partir desta data, exigindo, portanto maior investigação ou uma melhor qualificação quanto a este fenômeno.

BRAGA \& PAULA (1981:64, 65) deduzem sua afirmação a partir de gastos, "... a partir dos anos 60 , observa-se em termos de gastos, o declínio relativo da saúde pública e o crescimento da medicina previdenciāria ..." e como eles mes mos hipotetizam, uma das razões seria a tributação e sua es trutura, onde "... a Saúde Pública viu-se muito pouco aquinhoada ..." e, portanto, não poderia ser predominante. Neste sentido, parece pouco indicado comparar duas atividades complementares cujas fontes de tributação são bastante dife rentes, inclusive, porque mesmo em termos de Previdência, a União pouco participou, muito pelo contrário, caracterizou-se pelo declínio de sua participação.

Por outro lado, parte dos recursos destinada à Saú de Pública, na Secretaria, é canalizada para entidades priva das sob o rótulo de "Auxílio e Subvenções", inclusive para expansão da rede hospitalar privada, onde se desenvolverão as atividades ligadas à assistência médica previdenciária,sen do, portanto, aparente a divisão entre saúde Pública/Medicina Previdenciária. GRIECO, apud AMADO (1985:25) assim se expressa quanto aos recursos destinados ao controle de tuber culose: 
"Reconhecemos que no Brasil, tanto o governo fede ral como estadual sempre se interessaram pelas as sociações particulares, sempre incentivaram suas atividades, destinando-lhes verbas não desprezí veis, com objetivo de auxiliá-las a preencher sua finalidade."

o que os dados demonstram é que, realmente, as ações sanitārias nunca foram prioritárias a não ser em momen

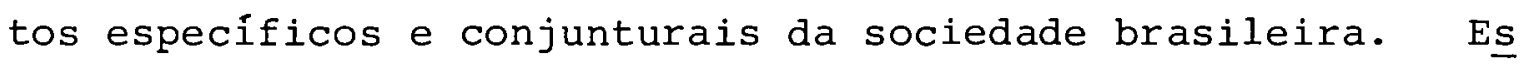
te fato não decorre de fatores orçamentários, mas resulta de fatores econômicos e políticos (inclusive internacionais, como se verá), sendo aqueles mera consequência. A falta de prioridade decorre, essencialmente, do caráter estrutural da Saúde Pública, como nota BERNIS (s/d:16, 17) "... a Saúde Pública responde, sem nenhuma dúvida, primeiramente, a neces sidades coletivas. Mas estas não são nem expressas, nem re conhecidas no sistema de produção de cuidados que, como o sistema de produção em geral, toma conhecimento de necessida des individuais ...", além do que, a Saúde Pública "... cor re o risco de por em questão o sistema econômico, colocando o problema das verdadeiras causas das afecções, enquanto a me dicina de cuidados não o faz, contentando-se em "reparar"..." Mas, no seu limite estrutural, ela assume importância como mecanismo de controle social ou sua potencialida de de contribuir para realização da mais valia através dos serviços, consumindo ou repassando bens de consumo.

Após 1942, o desenvolvimento das forças produti vas, nacional e internacional, acelera-se e esta nova condi- 
ção exigirá mudanças estratégicas na área de Saúde, inclusive internacionalmente.

FRANCO-AGUDELO (1984:122, 123), avaliando a ques tão da malária e a Fundação Rockfeller, observa que pós-40, há uma grande virada para um novo campo, a medicina

"... a grande virada da Fundação deu-se em 1952, ao assumir a sua Presidência Dean Rusk. Ficaram praticamente suspensos os programas diretos em doen cas tropicais; a atividade concentrou-se em: educa ção médica profissional, com apoio aos grandes centros especializados; atendimento médico, para continuar os programas iniciados na década anterior; pesquisa, com ênfase em virologia e, pouco depois, no novíssimo campo da medicina nuclear. Ex cetuando essas políticas, em 1961, por exemplo,pra ticamente todas as dotações da Fundação para saúde pública e ciências médicas foram feitas a Faculdade de Medicina, escolas de enfermagem, institutos de pesquisa ...", notando ainda que:

"... a Divisão de Medicina e Saúde Pública da Fun dação assim se expressa, em 1953: em contraste com os esforços iniciais, dirigidos para o controle di reto ou a eliminação de pragas específicas como a febre amarela, a malária ou a ancilostomíase, o programa atual adota a abordagem indireta. Seu ob jetivo imediato é o desenvolvimento de instituições locais para treinamento de pessoal e o avanço das pesquisas que a longo prazo proporcionarão be 
neficios permanentes nas áreas implicadas ..."

E evidente que este fato tem implicações na organi zação dos serviços de saúde, no Brasil. Parte da burocracia sanitária tenderá incorporar este campo de atuação, nas uni dades sanitárias existentes e isso dar-se-ā, basicamente, atra vés daquelas āreas já devidamente estabelecidas nas dēcadas anteriores, inclusive em nível hospitalar (lepra, tuberculose, materno-infantil) (13).

A incorporação da assistēncia médica e a influên cia americana, como exposta por FRANCO AGUDELO (1984), é as sinalada, também, por RODRIGUES (1967:158):

"... A assistēncia médica, depois de vārios anos proscrita das rotinas de saúde pública, a partir da década de 40 , passou a integrar definitivamente os serviços de qualquer unidade sanitária. Essa prática foi por nós adotada no Paraná, na Bahia;então - Serviço Especial de Saúde Pública tambēm compreendeu a necessidade da mesma, nos seus postos e o Congresso de Higiene, realizado em São Paulo, em 1948, endossou a recomendação nesse sentido ... Decorreram anos de dificuldade e incompreensões an tes que fosse vitoriosa a tese de que a saúde pú blica devia compreender não só os aspectos preventivos, mas igualmente os de recuperação da saúde.

(13) A ampliação da assistēncia médica encontrarā obstāculos dado ao fra co desenvolvimento das forças produtivas na ärea da saúde (disper são populacional, ausēncia de produção de bens de consumo duráveis ou não e formação de médicos), obstáculos estes que serão superados no final da década de 1960 . 
Grande óbice residia na doutrina sustentada, contrariamente, nos países desenvolvidos, particularmente nos Estados Unidos da América, de onde vị nham os figurinos seguidos então, pura e simples mente. A classe médica americana alinhava objeções à prática de assistência médica nas unidades sanitārias como prejudicial à livre empresa, daj advindo o critério seguido por nós! Entretanto, as condições financeiras, existentes nos Estados Uni dos e no Brasil, eram e são completamente diferentes, não comportando o assunto outra alternativa sı não a defendida inicialmente por restrito grupo de administradores brasileiros de saúde pública e hoje francamente aceita, já tendo mesmo a assistên cia médica sido o assunto das discussões tēcnicas da XVI Conferēncia Sanitária Pan-Americana, realizada em Minneapolis, EUA, no ano de 1962..." (RODRIGUES, 1967:158).

PESSOA (1960:188), tambēm, ressalta que a incorpo ração da assistência médica foi, em 1948, "... a tese aprovada pelo VII Congresso Brasileiro de Higiene. Eis o que dizem Candau e Braga: "A inclusão formal da assistência médi ca entre as funções de saúde pública das unidades sanitárias rurais é, no Brasil, apenas o reconhecimento de um fato que vem ocorrendo, disfarçadamente ou não, em todo o nosso Inte rior ..."

É no final da década de 1940 que aquelas áreas lle pra, tuberculose e atenção materno-infantill, ainda hoje bas 
bastante prevalecentes na Saúde Pública, iniciam sua sedimentação, correspondendo a uma nova expansão de desenvolvimento capitalista, e de intensa mobilidade da mão-de-obra nacional. Nesse momento, de concentração da classe trabalhadora nos grandes centros urbanos, de crescimento de sua fração operária e do exército industrial de reserva, tornava-se necessário delimitar os trabalhadores com direitos garantidos, na Previdência Social, e os doentes, os pobres, ainda que traba lhadores mas sem aqueles mesmos direitos.

A constatação de que algumas doenças atingiam a classe trabalhadora já havia sido detectada com relação, por exemplo, a tuberculose. Dos estudos de morbidade realizados pela Inspectoria de Profilaxia da Tuberculose, no periodo de 1927-1929, segundo BARROS BARRETO (1940:30), constava que ela prevalecia entre diferentes ocupações e, segundo ordem decrescente entre os trabalhadores 1) de serviços doméstị co, ocupações ligadas à alimentação e ao vestuário; 2) cons trução; 3) transporte e comércio; 4) profissões liberais, serviços de administrações e pessoas vivendo de rendimentos; 5) indústria textis e de madeira; 6) força pública e 7) cul tura do solo. Em 1935/37, dados do exército constatavam que "... os números de doentes baixados por tuberculose, nas di versas regiões militares, relacionados a 1000 homens de efe tivo médio de cada uma delas, evidenciam serem maiores as cí fras na Primeira Região (Distrito Federal e Estado do Rio), seguindo-se-lhes de perto a Segunda (São Paulo e Goiás)."

Ainda, segundo o mesmo autor, o Congresso Pan-Ame ricano de Tuberculose, em 1934, reconhecera como base econô mica da luta a instituição de um seguro obrigatório contra a 
doença. A criação de un seguro obrigatório especifico à tụ berculose possibilitaria, a assistência ao doente e seus familiares, isentaria os Institutos e Caixas de parte de um grande encargo, una vez que "... 50\% das aposentado rias por invalidez e percentual anālogo de pensões às famí lias correm, atualmente, por conta da tuberculose ..."(BARROS BARRETO, $1940: 71$ ).

A captação de recursos por este meio daria a saúde Pública maior autoridade, e, esta solução é defendida pelos sanitaristas "... para que se evitem as ações dispersivas,ine ficientes, deve caber privativamente à autoridade sanitária a gestão do seguro da doença, com amplos poderes de fiscalização na aplicação dos recursos e mesmo depois, da melhor forma, de utilizá-los em determinadas circunstāncias ...". (BARROS BARRETO, 1940:71, 72).

No entanto, essa forma de captação de recursos não se verificou mas a tuberculose passa a se incorporar, defini tivamente, ao aparelho estatal, isentando a Previdência desse encargo. A tentativa de incorporação jā se verifica, na década de 20, quando em São Paulo, são criadas as Prefeitú ras Sanitárias, das quais sobressai a de Campos de Jordão, criada pela Lei no 2140, de 01 de outubro de 1926, dando "... poder ao governo para nomear seu prefeito, fiscalizar aplicação de verbas, melhorar e aparelhar aquela estância pa ra profilaxia e tratamento da tuberculose ..." (MABCARENHAS, 1948:104). A criação da Prefeitura Sanitária de Campos de Jodão continua a obra de Emilio Ribas que, em 1912, recebeu concessão para a implantação de uma rede ferroviāria de Pin 
damonhagaba a Campos de Jodão (TAMEIRÃo, 1962:70-71; Arq. Hig., 1936), onde "... grande maioria das organizações par ticulares estabeleceu seus hospitais e sanatórios ..." (AMADO, $1985: 23,30)$.

Contudo, a Saúde Pública não só não consegue cap tar recursos de outras fontes como não implanta o modelo em que se inspirou, "o modelo "Philips do Edinburg Tuberculosis Scheme, do final do século, combinando a atuação dinâmica do dispensário com isolamento sanatorial ..." (AMADO, 1985: 27). Entre 1938 a 1941, duas medidas de impacto sobressaem na área da saúde, o início da construção do Hospital das Clí nicas, em São Paulo e de numerosos sanatórios de Tuberculose (FGV-CPDOC, 1984).

AMADO (1985) assinala que o modelo foi aplicado no sentido inverso, dando primazia aos sanatórios, sendo uma ún ca exceção o Dispensário, fundado em 1904, por Clemente Fer reira. Mostra também, que, após 1930, com introdução de no vos métodos terapêuticos, tanto clínicos como cirúrgicos, a infinidade de instituições filantrópicas não tinham como ar car com os custos deste tipo de assistência. A introdução de novos métodos como a colapsoterapia que "... poderia ser, aplicado ambulatoriamente veio atribuir ao dispensário novas funções que, segundo Grieco, era possivel encarar, separadamente, o problema médico e profilático ... (apud AMADO,1985: 31) e diante da escassez da rede hospitalar, o dispensário obrigava-se a assumir função terapêutica, o qual este não dẹ veria se esquivar, conforme Paula Souza (apud AMADO, 1985: 31). 
A eficiência reduzida dos sanatórios era enfatizą da por Paula Souza que afirmava que o "... nümero de indiví duos que saem do hospital sem que se beneficiem em nada ou quase nada, é elevadissimo, sendo considerado tão contagiante quanto no momento de sua entrada ..." (AMADO, 1985:35)

Entretanto, o modelo implantado pelas entidades privadas, dando ênfase ao atendimento sanatorial prevaleceu. Os princípios do Serviço Nacional de Tuberculose, que deve riam regulamentar o controle contra tuberculose e apresentados na lạ Conferência Nacional de Saúde, em 1941, enfatiza ram a necessidade de expansão do número de leitos, em hospi tais gerais e/ou em sanatórios, o que se verifica a partir da quela data.

Como acentua AMADO (1985), o avanço dos conhecimen tos e técnicas, ao invēs de possibilitar uma melhoria, provo cava um sentido inverso; a introdução da quimioterapia, em 1940, no Brasil, diminuia eficiência do tratamento sanatorial e piorava o quadro epidemiológico da tuberculose, devido ao tempo de permanência hospitalar alta (253, em 1949, a 302 dias, em 1953), altas de pacientes baciliferos, alto cus to do leito dia $\operatorname{Cr} \$ 49,64$, entre 1951/1956 a $\operatorname{Cr} \$ 51,34$, em 1956), redução de queda da mortalidade e aparecimentos de doentes crônicos, "... salvos da morte.... porém não conse guiam a cura pela não aplicação correta do tratamento $100 \%$ ..." (AMADO, 1985:54)

A ênfase no tratamento sanatorial e a limitação das funções dos dispensários, aos quais cabia apenas diagnosticar e encaminhar para tratamento, assim como o escasso número (14) A quimioterapia recem-utilizada apresentava indices de cura próximos a $100 \%$. 
de dispensários existentes, (apenas 27 em todo Estado) invia bilizam o tratamento ambulatorial, fragmentando a assistên cia.

Viabilizam, contudo, a expansão de construção de hospitais, do consumo de uma série de equipamentos e medicamentos como, por exemplo, a utilização da abreugrafia, que passa a ser uma exigência legal na admissão ao trabalho, já estabelecida pela Consolidação das Leis do Trabalho (CLT).

No Estado de São Paulo, como mostra AMADO (1985: 46), o orçamento da Divisão de Serviço de Tuberculose mostra, claramente, a magnitude de investimentos. De 1932 a 1945 , - item tuberculose consumia anualmente entre 0,94 e 2,05\% das despesas totais anuais do gasto estatal em saúde. A partir de 1946, esta porcentagem subiu para 15,38\% e depois, gradativamente até $29,18 \%$ em 1951 ... investimentos, realizados especialmente em serviços hospitalares ..."

Em 1946, a nova Constituição enfatiza a necessida de de construção hospitais contra os flagelos sociais, entre os quais a tuberculose. Em vista disso, a Secretaria de Saú de propõe-se construir sete hospitais no Estado e,efetivamen te, inicia-se a contrução de quatro (Botucatu, Lins, Catanduva e Araraquaral, apesar de que, desde esta data, a desco berta da quimioterapia favorecesse o atendimento em dispensā rios.

Em 1947, a Seção de Tuberculose, criada em 1931, passa constituir a Divisão de Serviço de Tuberculose da Se cretaria de Saúde.

No final da década de 1950 e início de 1960 "... 
a politica sanitária, que vem se intensificando e ampliando, consiste no diagnóstico precoce pela abreugrafia em massa... - Plano de Ação previu a instalação de novos dispensários... bem como a aquisição de 12 unidades móveis de abreugrafia (CARLOS, 1962:77). Dentro da mesma política, para os casos de internação e dentro da "... política de cooperação com en tidades assistenciais privadas, procurou-se ampliar os números de leitos em convênio que já atingiram 900, em 1961 ..." (CARLOS, 1962:77)

Em ambos os casos, os serviços privados são favore cidos. Não conseguindo, os dispensārios atender a demanda legal, canalizam-na para os serviços privados, que prolife ram junto às Delegacias de Trabalho e que, provavelmente, de veriam ser compostos por elementos do próprio serviço público. A canalização da clientela dos serviços públicos paraos privados constituirá uma prática incorporada, não só em tex mos de prestação de serviços médicos como no de serviços de diagnóstico com a introdução e expansão daqueles métodos, bạ seados em exames complementares considerando-se, inclusive, a precariedade na manutenção de equipamentos dos serviços públicos de saúde. Essa necessidade, criada pelo serviço de saúde e legalmente fixada, possibilita a maior demanda e, portanto, o consumo de bens, mesmo quando desnecessário tecnicamente.

4. A CRIANCA, O TRABALHADOR RURAL E A NECESSIDADE DO CONTROLE DA IRRACIONALIDADE (POLITICA) (1945 - 1964) O regime político, implantado em 1945, não rompe 
totalmente com o regime anterior, permanecendo, praticamente, inalteradas as estruturas anteriores. Em 28 de maio de 1945, - Decreto-Lei no 7586 institui os partidos nacionais, surgin do quinze partidos políticos; em 1948, cassa-se o direito do Partido Comunista Brasileiro, que obtivera, nas eleições de $1945,8 \%$ dos votos (RODEE et alii, 1959).

O sistema multipartidário, surgido pós-45, beneficiará os grandes partidos ligados ao regime anterior, o Par tido Social Democrático - PSD - que absorve as interventorias e as bases municipais, "... estruturando-se em são Pau lo como grande partido de clientela ligado à máquina burocrá tica: à Caixa Econômica Federal, às Coletorias, às Secções de Imposto de Renda ..." (CARDOSO, 1975:53) e o Partido Tra balhista Brasileiro - PTB, incorporando as clientelas urba nas ou cobertas pelas instituições previdenciārias. Contudo, parte desta massa é absorvida, em nível estatal, pelo Partido Social Progressista - PSP (15), que contava com uma máqui na política, estruturacia no Estado Novo, compondo-se de par tido e burocracia estatal, como sistema de participação polí tica das massas.

Sob intervenção de Adhemar de Earros "... a assistência ao interior foi dirramizada atravēs do Departamento de Muricipalidądes, örgão diretamente subordinado ao Interven tor, que abriu créditos especiais as obras de saneamento e

(15) Surgido, em 1945, da fusão do Partido Republicano Progressista (PRP) e dos partidos Paulista Popular e Sindicalista (PPS) e Agrärio Nacional (PAN), tendo como lider principal, Adhemar de Barros, interven tor estadual (1938-1942); governador de Estado (1947-1951 e 1964-196б), candidado a Presidente da República (1955); prefeito de Sáo Paulo (1957-1961). Formado em Medicina, em 1923, no Rio de Janeiro,cursou a Universidade Popular de Berlim de 1924 a 1928, trabalhando, entre 1928 a 1932, no Instituto Oswaldo Cruz (FGV-CPOC, 1984:371, 323,2591, 2597). 
inplantou um sistema de financiamento mais flexível para as prefeituras, com taxas de juros menores (FGV-CPDOC, 1984 : 317).

E bastante interessante o depoimento do Sr. Mário Beni, um dos líderes do partido sobre a atuação partidária:

"... E claro que o PSP quando elegeu o governador, não tinha a totalidade do Estado porque elegeu ape nas 9 deputados ... Mas depois de 1947, o governa dor, então Adhemar, em determinado período, foi substituindo os prefeitos, por decretos ... Ele (Adhemar) destituia prefeitos e nomeava para pre feitos correligionários seus e foi se fortalecendo Quando vieram as eleições, as municipais, os que comandavam o executivo dos municipios lideravam as eleições e deram ao PSP uma vitória fabulosa... As zonas de influência do PSP eram todo o Estado ... eram diversificadas ... O PSP tinha por norma esta belecer zonas de influência dos candidatos a deputado, como se faz no regime de distritos regionais ... Naquela zona (Mogiana) não faltava nada, por que eu trabalhava só para ela, porque ela me deu os votos. Da mesma maneira o PSP estabelecia re giões para outros candidatos, como por exemplo, Lu ciano Nogueira Filho no novo Estado de São Paulo, que é Osvaldo Cruz, Marília, Tupã... Geraldo Bar ros era São Manuel, Botucatu. Carvalho Sobrinho Botucatu. Eles iam para Avaré, iam para Itapetinin ga, então nós tínhamos uma divisão total do parti 
do ..." (CARDOSO, 1975:51). O mesmo autor, assina la que, na caracterização usual do PSP "... é o de que ele foi um partido populista e fez uso do esti lo clientelismo tradicional." Nota, também, como característica o fato de que, através dele, "abriü se a possibilidade de setores sociais em ascensão participar dos negócios de estado e em função do lobbysmo ... E de fato, por intermédio dele (PSP), alguns descendentes de imigrantes ... enriquecidos com a guerra e a industrialização passaram a atuar na politica paulista e a fazer negócios junto ao Estado ..." (CARDOSO, 1975:52).

A base clientelistica, construida por Adhemar de Barros desde o Estado Novo, como Interventor Federal, entre 1938 a 1941 manterá a forte influência do PSP, mesmo quando o partido estava alijado da máquina estatal. Tendo suas bases populares sido minadas por Janio Quadros nas ele ções municipais, de São Paulo, recuperou-se, em 1957, com eleição do Adhemar de Barros para Prefeito e mais tarde (1964 - 1966) como Governador (CARDOSO, 1975).

A Tabela 7 mostra o predominio do PSP na Assem bléia Legislativa entre 1950 a 1962; apenas, em 1947, o PSP e PTB o superam.

Dentro deste quadro político, a estrutura da secre taria de 1948 será mantida, fortalecendo seus principais De partamentos e, assumindo, com maior peso também, a assistência social,e a colaboração com entidades de nível fe deral e internacional. Esta assunção reflete as mudanças 
TABELA 7 - Composição dos partidos na Assemblēia Legislativa, Estado de São Paulo, 1947, 1950, 1954, 1958, 1962

\begin{tabular}{|c|c|c|c|c|c|}
\hline Partido & 1947 & 1950 & 1954 & 1958 & $1962(*)$ \\
\hline PSP & $\begin{array}{r}12.0 \\
(9)\end{array}$ & $\begin{array}{l}25.3 \\
(19)\end{array}$ & $\begin{array}{l}22.7 \\
(17)\end{array}$ & $\begin{array}{l}17.6 \\
(16)\end{array}$ & $\begin{array}{l}17.4 \\
(20)\end{array}$ \\
\hline PSD & $\begin{array}{l}34.7 \\
(26)\end{array}$ & $\begin{array}{r}12.0 \\
(9)\end{array}$ & $\begin{array}{l}14.7 \\
(11)\end{array}$ & $\begin{array}{l}7.7 \\
(7)\end{array}$ & $\begin{array}{l}17.4 \\
(20)\end{array}$ \\
\hline РTB & $\begin{array}{l}18.7 \\
(14)\end{array}$ & $\begin{array}{l}16.0 \\
(12)\end{array}$ & $\begin{array}{r}10.7 \\
(8)\end{array}$ & $\begin{array}{l}6.6 \\
(6)\end{array}$ & $\begin{array}{l}10.4 \\
(12)\end{array}$ \\
\hline $\mathrm{PR}$ & $\begin{array}{l}4.0 \\
(3)\end{array}$ & $\begin{array}{l}4.0 \\
(3)\end{array}$ & $\begin{array}{l}9.3 \\
(7)\end{array}$ & $\begin{array}{l}7.7 \\
(7)\end{array}$ & $\begin{array}{l}11.3 \\
(13)\end{array}$ \\
\hline PTN & - & $\begin{array}{r}12.0 \\
(9)\end{array}$ & $\begin{array}{l}9.3 \\
(7)^{3}\end{array}$ & $\begin{array}{l}11.0 \\
(10)\end{array}$ & $\begin{array}{l}16.5 \\
(19)\end{array}$ \\
\hline UDN & $\begin{array}{r}12.0 \\
(9)\end{array}$ & $\begin{array}{l}13.3 \\
(10)\end{array}$ & $\begin{array}{l}9.3 \\
(7)\end{array}$ & $\begin{array}{r}10.0 \\
(9)\end{array}$ & $\begin{array}{l}9.6 \\
(11)\end{array}$ \\
\hline PSB & - & $\begin{array}{l}2.7 \\
(2)\end{array}$ & $\begin{array}{l}5.3 \\
(4)^{3}\end{array}$ & $\begin{array}{l}6.6 \\
(6)\end{array}$ & $\begin{array}{l}1.7 \\
(2)\end{array}$ \\
\hline PDC & $\begin{array}{l}2.7 \\
(2)\end{array}$ & $\begin{array}{l}6.7 \\
(5)\end{array}$ & $\begin{array}{l}5.3 \\
(4)^{3}\end{array}$ & $\begin{array}{l}12.1 \\
(11)\end{array}$ & $\begin{array}{l}10.4 \\
(12)\end{array}$ \\
\hline PRP & $\begin{array}{l}1.3 \\
\text { (i) }\end{array}$ & $\begin{array}{l}2.7 \\
(2)\end{array}$ & $\begin{array}{l}4.0 \\
(3)\end{array}$ & $\begin{array}{l}5.5 \\
(5)\end{array}$ & $\begin{array}{l}6.1 \\
(7)\end{array}$ \\
\hline PST & - & $\begin{array}{l}1.3 \\
\text { (1) }\end{array}$ & $\begin{array}{l}4.0 \\
(3)\end{array}$ & $\begin{array}{l}6.6 \\
(6)\end{array}$ & $\begin{array}{r}8.7 \\
(10)\end{array}$ \\
\hline PRT & - & $\begin{array}{l}2.7 \\
(2)\end{array}$ & $\begin{array}{l}4.0 \\
(3)\end{array}$ & $\begin{array}{l}6.6 \\
(6)\end{array}$ & $\begin{array}{l}7.8 \\
(9)\end{array}$ \\
\hline PI & - & $\begin{array}{l}1.3 \\
\text { (i) }\end{array}$ & $\begin{array}{l}1.3 \\
(i)\end{array}$ & $\begin{array}{l}2.2 \\
(2)\end{array}$ & - \\
\hline PCB & $\begin{array}{l}14.7 \\
(11)\end{array}$ & - & - & - & - \\
\hline ED & - & - & - & - & - \\
\hline TOTAL & $(75)$ & $(75)$ & (75) & (91) & (115) \\
\hline
\end{tabular}

(*) Em 1962, hā duas importantes coligações: PSP - PSD, com 20 deputados eleitos e PTN - MTR, com 19.

FONTE: CARDOSO (1975:48).

sócio-econōmicas pós-guerra, como se verá posteriormente. De Secretaria de Educação e Saúde Pública, SESP - desde 1931, passa, em 1947, a Secretaria de Saúde Pública e Assistência 
Social - SSPAS -. Nesta nova reestruturação da Secretaria, a Seção de Tuberculose passa a ser Divisão, e a Seção de Hi giene da Criança e o Serviço de Puericultura a se constituírem no novo Departamento Estadual da Criança, demonstrando o novo espaço burocrātico da década de 50, a assistência mater no-infantil, espaço este que a tuberculose não consegue al cançar, apesar de sua importāncia em termos de mortalidade e morbidade, e talvez até devido a sua metáfora, como mostra SONTAG $(1984: 21)$.

"A tuberculose é sempre imaginada como uma doença da pobreza e da privação - falta de roupas, corpos magros, quartos sem aquecimento, higiene deficiente, alimentação inadequada. A pobreza pode não ser tão literal quanto no sotão de Mimi, em "La Bohème", a tuberculosa Marguerite Gauthier, em "A dama das Camélias", vive no luxo mas por dentro ela é um trapo $\ldots$.

Mas "um trapo" que não tem a transparência da le pra e é, portanto, mais aceita em termos de circulação e a grande problemātica, em termos de circulação, será o homem do campo, do interior e motivo de preocupação governamental. Se a tuberculose não mostra a sua transparência, adquiremna os milhares de trabalhadores que se deslocam para os cen tros urbanos e passam a avolumar-se. E se, em 1933, a secre taria jā criara uma Comissão de Assistência, cujos recursos são incorporados à assistência hospitalar (MASCARENHAS, 1949), em 1948, com a reformulação dos órgãos públicos, após a Cons tituinte de 1946, ela reafirma sua posição no domínio desta 
área assistencial, e a assume até a década de 60 .

Esse volume de trabalhadores, deslocado de várias ăreas do Estado e do Brasil, corresponde às necessidades in dustriais, desenvolvidas num periodo favorável de proteção, proporcionado pela Segunda Guerra Mundial (1938 - 1945). Se até 1940, grande parte da população vivia em área rural, es ta situação se modifica a partir de então. A Tabela 8 mos tra a distribuição da população em áreas urbana e rural. O므 serva-se, que, em 1940, 55,9\% da população do Estado de São Paulo viviam em área rural, invertendo-se a partir de então com o predomínio da população urbana no Estado como um todo e, na década posterior, também no interior.

TABELA 8 - População relativa urbana e rural, Estado de são Paulo, 1940/1970

\begin{tabular}{lrrrrrrrrr}
\hline \multirow{2}{*}{ Area } & \multicolumn{2}{c}{1940} & \multicolumn{2}{c}{1950} & \multicolumn{2}{c}{1960} & \multicolumn{2}{c}{1970} \\
\cline { 2 - 8 } & Urbana & Rural & Urbana & Rural & Urbana & Rural & Urbana & Rura1 \\
\hline Estado & 44,2 & 55,9 & 52,6 & 47,4 & 62,8 & 37,2 & 80,3 & 19,7 \\
Capita1 & 94,9 & 5,1 & 93,4 & 6,6 & 88,0 & 12,0 & 99,1 & 0,9 \\
Interior & 32,6 & 67,4 & 39,7 & 60,3 & 52,7 & 47,3 & 70,9 & 29,1
\end{tabular}

FONTE: SAAD $(1980: 18)$

MÜLLER (1982:264) observa que a "... desruralização da população da região Sudeste, mormente a do Estado de são Paulo, ocorre pelo menos uma década antes da do restante do país, exceção feita ao Estado do Rio de Janeiro (Guanabara). .." A Tabela 9 mostra as taxas médias de incremento anual, 
no Estado de São Paulo, observando-se maior crescimento para população urbana, atingindo seu ponto máximo entre 1960/1970, para posterior decréscimo.

TABELA 9 - Taxas médias de incremento anual da população to tal, urbana e rural, Estado de São Paulo, 1940/ 1980

\begin{tabular}{cccc}
\hline \multicolumn{1}{c}{ Área } & Total & Urbana & Rural \\
\hline Periodo & 2,44 & 4,25 & 0,77 \\
$1940 / 1950$ & 3,44 & 5,26 & 1,01 \\
$1950 / 1960$ & 3,33 & 4,94 & $-3,10$ \\
$1960 / 1970$ & 3,49 & 4,51 & $-2,04$ \\
\hline
\end{tabular}

FONTE: MÜLLER (1982:265).

O incremento da população urbana verifica-se, con comitantemente, com o aumento de número de municípios, con forme Tabela 10 e que ocorre, principalmente, nos períodos de $1940 / 1960$.

TABELA 10 - Número de municípios existentes, taxas de acréscimo, Estado de São Paulo, 1940/1960

\begin{tabular}{lccc}
\hline Periodo & $\begin{array}{l}\text { No de municipios } \\
\text { existentes no ini } \\
\text { cio do periodo }\end{array}$ & $\begin{array}{l}\text { No de municipios } \\
\text { existentes no fi } \\
\text { nal do periodo }\end{array}$ & Acréscimo \\
\hline $1940 / 1950$ & 270 & 369 & $36,7 \%$ \\
$1950 / 1960$ & 369 & 505 & $36,9 \%$ \\
$1960 / 1970$ & 505 & 571 & $13,1 \%$ \\
$1970 / 1980$ & 270 & 571 & $11,5 \%$ \\
\hline
\end{tabular}

FONTE: SAAD (1980:7). 
Em sua análise desse processo de desruralização, MÜLLER (1982:263) assinala que "... ele expressa o aumento de produtividade do trabalho no campo juntamente com altera ções de padrões de produção e consumo que, a grosso modo, ten dem a assemelhar-se aos padrões urbanos ...", alterações es tas que significam uma maior mercantilização ou seja expan são de um mercado interno.

o agravante da situação é que, conforme LOPES (1968:18), nas cidades não industriais a urbanização é mais intensa. Observando-se a Tabela 1l,verifica-se que o cresci mento das cidades, na década de 1940/1950 deu-se, principalmente, naquelas com até 10.000 habitantes. Nota ainda o au tor que "... o crescimento dessas cidades não industriais, entretanto, ocorre com uma parcela maior de desocupação e subocupação ..."

TABELA 11 - Distribuição dos municipios, segundo grupo de ha bitantes 1940/1980

\begin{tabular}{crrrrr}
\hline $\begin{array}{c}\text { Grupo de } \\
\text { habitantes }\end{array}$ & 1940 & 1950 & 1960 & 1970 & 1980 \\
\hline até 5.000 & 9 & 24 & 70 & 118 & 153 \\
$5.001-10.000$ & 57 & 112 & 169 & 179 & 120 \\
$10.001-20.000$ & 101 & 120 & 133 & 129 & 122 \\
$20.001-50.000$ & 81 & 91 & 101 & 99 & 99 \\
$50.001-100.000$ & 19 & 18 & 19 & 23 & 43 \\
mais de 100.000 & 3 & 4 & 11 & 23 & 34 \\
\hline T O T A & 270 & 369 & 503 & 571 & 571 \\
\hline
\end{tabular}

FONTE: FIBGE $(1981: 3)$. 
A preocupação com presença desta massa de desocupados em centros urbanos é atestada já, em 1941, pelo estudo sobre problemas de bases do Brasil, elaborado naquele ano, pela Secretaria Geral do Instituto Brasileiro de Geografia e Estatistica - IBGE - (1948:66), assinalando-se entre outros objetivos daquele momento:

"a) aliviar os atuais centros metropolitanos das massas demográficas que para eles acorreram e estão sobrando na sua organização social e eco nômica, em virtude da debilidade orgânica do país ...

"b) efetuar a transladação demográfica num esforço simultâneo que vise a regenerar, pela higienização, pela alimentação, pela educação e socialização intensiva, os elementos componentes das massas a deslocar, a fim de que possam elas formar, nas regiōes interiores a que se transferirem, uma sociedade normal e de alto teor de eficiência ..." (16).

Diante da crise mundial, tornara-se necessária, a reestruturação e reorganização da vida nacional, por meio de medidas de base entre as quais a criação do "Exército de Tra balho", para ocupação das novas metrópoles interiorizadas, in clusive o novo Distrito Federal, no Estado de Minas Gerais e sua adaptação aos novos ambientes através de:

(16) Assim como nas décadas de $10 / 20$, o binômio higiene-educação, divu1gado pela Cruzada de Medicina pela Pátria e pela Campanha Nacional, em prol da Construção Nacional, é visto como salvação da democracia e regeneração da raça (LABRA, 1985), aqui apresenta-se para constrü ção de uma "sociedade normal e alto teor de eficiencia." 
"... a) a obra intensiva de assistência sanitāria, educativa e econômica sobre as massas demográficas que permanecem desocupadas ou mal ocupadas nas cí dades atuais ...

b) submissão inicial destas massas ao regime mili tar, a fim de tornar-lhes mais fácil o comando e mais eficiente o trabalho e, ao mesmo tempo, na in tenção de criar uma reserva poderosa, sem ônus es pecial, à disposição das Forças Armadas para o caㅡ so de emergência ..." (IBGE, 1948:70, 71).

Esta "... grandiosa obra colonizadora e de constru ção nacional sob auspícios do Exército", por outro lado, pre pararia os elementos de seu quadro para "... uma excelente escola prática de empresas enérgicas e um meio de cultivarem o espirito de iniciativa, ficando assim ao mesmo tempo articulado esse esforço de reconstrução nacional com as necessidades de defesa do país ..." (IBGE, 1948:72).

Propõe-se, ainda, a instituição de colônias-escolas para "... atrair por contrato de trabalho e concentrar em pontos convenientes do seu próprio "habitat" (sem desambien tá-las, portanto) as famílias de nível miserável de vida,ora dispersas nas zonas rurais e semi-āridas dando-lhes, a "va lência" social e a existência condígna, de que estão dolorosamente privadas e prestar a estes elementos desdobrada as sistência sanitāria e educativa, no intuito de regenerā-los e reajustá-los ao meio social ...". Após a passagem nas co lônias-escolas, "... estas famỉlias regeneradas" seriam fixa das em colônias-modelos, tornando-se os povoadores eficien 
tes e bem socializados das zonas rurais, como seus explorado res por conta própria ou como seu proletariado ..." (IBGE, $1948: 71)$.

Parcela desta massa, realmente, passará a constí tuir a clientela dos asilos-colônias para os doentes mentais, tuberculosos e leprosos, onde também se valorizará o trabą 1ho, a disciplina. Os últimos, organizados em caixas benefi cientes por intermédio do Serviço de Profilaxia de Lepra, rea lizam obras diversas como: construção de igrejas, restauran tes, cine-teatros, escolas, praças de esporte, e, "... em consequência da colaboração entre Estado e instituições de Combate ao Mal de Hansen, há mais de 2.000 leprosos traba lhando remunerada e permanentemente. Esses enfermos, sem o menor risco de contagiar a população sã, estão em tratamento, enquanto produzem. o seu trabalho rende mensalmente 89:238\$956 ...", tendo um patrimônio, em 1938, de 3.665.770\$019..." (Arq. Hig., 1940a:336, 337).

Como nota DIAS (1985:265) com relação ao doente mental, "... a ética do mundo burguês, fundada na disciplina, aproxima os banidos mesmo que impossibilitados de saírem do isolamento, seu tempo é preenchido pelo trabalho, o ócio é o maior pecado dessa sociedade. Daí a construção de colôniasagrícolas ..."

Contudo, embora se afirmasse que o Brasil era um imenso hospital, as novas condições pós - 42 do desenvolvimen to capitalista impediam o confinamento dessa imensa massa quer seja em asilo-colōnia ou colōnias-modelos, ao contrário, exigiam uma maior circulação da mercadorias, inclusive da 
mão-de-obra interna e sua concentração em āreas, já anterior mente, industrializadas.

As novas condições redefinem a relação Estado e So cèedade, internamente e as relações capitalistas internacionais, gerando novas contradições à sociedade brasileira.

Em 1942, como resultante da II Guerra Mundial, cria-se a ONU "... com a finalidade de preservar a paz mun dial ...", assim como órgãos especializados como a CEPAL, OIT, FAO, OMS. A Conferēncia de Yalta, em 1945, já resultara na divisão do mundo em países do bloco capitalista e comu nista constatando-se a presença de um bloco de países, que constituia o Terceiro Mundo. O confronto entre as duas po tências dominantes, os Estados Unidos e União Soviética, de nominou-se "Guerra Fria" e seus princípios foram formulados pela Doutrina Truman, em 1947, com a finalidade de preservar a hegemonia americana entre paises capitalistas ocidentais. Este fato permite aos Estados Unidos, a intervenção nos as suntos internacionais dos países capitalistas, intervenção es ta acentuada com a Revolução Chinesa (1949) e, posteriormente, com a ruptura da unidade do sistema capitalista na Améri ca, com a Revolução Cubana, em 1959.

A politica americana, adotada por Truman, dará ên fase ao fornecimento de alimentos, rações animais e fertilizantes para aumento da produção agrícolas dos países depen dentes, tendo como justificativa ideológica o combate à fome e à miséria, que poderiam tornar os povos famintos recepti vos às idéias comunistas, cabendo aos Estados Unidos "...ofe recer aos países amigos, afirmara Truman no seu discurso de 
posse, os benefícios de nosso cabedal de conhecimentos técni cos e ajudá-los a realizar suas aspirações por uma vida me lhor ..." (AMMANN, 1985:30).

Dentro desta perspectiva, em 1947,"... reuniu-se, em Petrópolis, a Conferência Interamericana para Manutenção da Paz e da Segurança no Continente, prestigiada pelo presi dente norte-americano, Truman ... Assinava-se o Tratado de

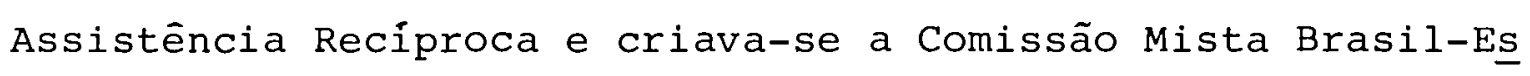
tados Unidos, além de outras análogas para o fim de mais es treita colaboração entre as Repúblicas do Continente ...". (BELLO, apud IANNI, 1986:115). Em 1949, o mesmo presidente anunciou o Ponto IV, visando fornecer assistência técnica e financeira a diferentes setores econômicos, educacional, agri cola e militar (IANNI, 1986).

Nos acordos estabelecidos, incluem-se aqueles des tinados as populações rurais com a criação de associações ru rais, sob auspícios da American International for Economic and Social Development, criado pelos Rockfeller (AMMANN, $1985)$ e tendo como método de intervenção local o desenvolvimento de comunidade (17). A revolução cubana, em 1959, for talecerá o programa de assistência tēcnica e financeira ame ricana, via OEA e por meio da chamada Operação Pan-Americana (OPA), apresentada nos anos 50 e posta em prática em 1961/63, com a Aliança para o Progresso.

No Brasil, os acontecimentos mundiais pós-42 re sultam na luta pela democratização do país e na nova consti-

(17) Sobre assunto AID (1964) v. AMMANn (1985), DonnAngelo (s/d). 
tuição de 1946. Contudo, assiste-se a uma profunda transfor mação no desenvolvimento das forças produtivas, acelera-se o processo de urbanização e constata-se uma maior presença po litica dos trabalhadores.

A Tabela 12 mostra a participação da população na escolha presidencial a partir da década de 1920, verificando - se a duplicação do nümero de votantes entre 1930/45, elevan do-se, lentamente, após o período.

TABELA 12 - Distribuição da população e porcentagem de votan tes nas eleições presidenciais, 1922/60

\begin{tabular}{ccc}
\hline A n & $\begin{array}{c}\text { População } \\
\text { (milhões) }\end{array}$ & $\begin{array}{c}\text { o votantes } \\
\text { da população }\end{array}$ \\
\hline 1922 & 28.5 & 2.9 \\
1922 & 30.9 & 2.3 \\
1930 & 33.5 & 5.7 \\
1945 & 46.2 & 13.4 \\
1950 & 51.9 & 15.9 \\
1956 & 58.9 & 15.6 \\
1960 & 70.1 & 17.8 \\
\hline
\end{tabular}

FONTE: RETRATO DO BRASIL (1984:15).

Mas, se a democratização resulta na conquista do direito político de uma maior parcela da população, ela não traz a ampliação de direitos sociais, gerando tensões. Face a estas, acentua-se nas Campanhas de Reconstrução Nacional, a valorização do homem, agora rural, que predominará no discur so governamental. 
Neste processo de reconstrução nacional são contem plados, na saúde, a atenção materno-infantil e as propostas de assistência médico-social rural que passam a constituir,a partir da década de 50, objetos de maior interesse estatal.

As atividades, desenvolvidas na área materno-infan til, iniciam-se, no começo do século, com a inspeção das amas de leite, passando, paulatinamente, a higiene e assistēncia à criança (MASCARENHAS, 1949). Contudo, o Estado amplia sua atuação na atenção à criança, com o surgimento, em 1940, do Departamento Nacional da Criança e, em nível estadual do De partamento Estadual da Criança (DEC), em 1944, aglutinando atividades dispersas na Secretaria de Educação e Saúde Pública(SESP).

A ampliação desta área estatal, assim como aquelas referentes à lepra e à tuberculose, è precedida pela mobilização de médicos e entidades filantrópicas em torno da fome, desnutrição,da questão nacional. Posteriormente, fundam-se entidades filantrópicas, dedicadas à criança. Entre 1901 a 1927, segundo SPOSATI (1985) houve profileração destas instí tuições. Em 1922, realiza-se o I Congresso Brasileiro de Proteção à Infāncia. Em 1932, "... Getúlio Vargas ... o pri meiro Chefe de Nação a preocupar-se com a importāncia que assumia para nós, a proteção à infāncia e à maternidade... na sua Mensagem de Natal, ecoando por todo o Brasil ... concla mou os Interventores para tão patriótica cruzada ..." (Arq. Hig., 1940c:285). Em 1937, cria-se o Instituto Nacional da Criança e em comemoração aos 12 de outubro, institucionaliza da pelo Decreto no 4867 de 1924, como dia da festa da criança, celebra-se a Semana da Criança, em todo território nacio 
nal. Nos dois acontecimentos, a criança é enaltecida como futuro da nação.

"... celebrada a Semana da Criança, destinada a disputar onde não existe e a intensificar onde já existe, a convição de que do interesse e do prepa ro que lhes merecem as novas gerações depende fun damentalmente o futuro da nacionalidade ..." (Arq. Hig., 1940b:339). " ".. atendendo à necessidade fun damental de zelar pelo aperfeiçoamento da raça e defender as fontes de renovação do organismo da na cionalidade, o governo da República sob a direção esclarecida do Presidente Getúlio Vargas, traçou pạ ra todo o país um largo programa de proteção à ma ternidade, à infância, à adolescência ... o Gover no Nacional empenha-se decididamente na valorização do elemento humano nacional e no preparo eugênico e racial da infāncia e da juventude para que elas possam enfrentar e vencer as inegáveis dificuldades da vida social contemporânea ..." (Arq. Hig.,1940c: 287).

Simultaneamente, são realizadas demonstrações pụ blicas de educação física, sessões solenes, visita e distribuições de brinquedos, concurso de robustez e irradiados e publicados artigos, comentários sobre a criança, com intensa propaganda pelo rádio e jornais.

Em 1945, não só se realiza a Semana da Criança cọ mo a Campanha da Redenção da Criança. Para esta redenção, cô mo ressalta o Diretor do Serviço de Centros de Saúde da Capi 
tal, necessita-se da colaboração tanto dos pobres como dos ricos "... para que por intermédio do rádio, imprensa e pa lestras, soasse, em todos os lares, a voz amida dos batalhadores da Cruzada do Bem, a penetrar fundo nos ambientes Sa grados da familia para pedir aos ricos a sobra de suas migalhas em prol de tão noblitante campanha e aos pobres a' coope ração de sua frequência aos serviços de assistência a Maternidade e Infância, mantidos pelos poderes públicos e institui ções particulares, nos Centros de Saúde ou Postos de Puericul tura ... que, por certo, valorizada a saúde de seus filhos, terão maior desenvolvimento econômico, maior fomento à rique za pública ..." (Arq. Hig., 1945:151).

Nessa mesma data, a Legião Brasileira de Assistẹn cia - LBA - contribui com elevados donativos a todo interior para instalação de mais de 50 postos de puericulturas nos di ferentes municipios. E esta entidade ${ }^{(18)}$ que parece ser responsável pela instalação dos primeiros postos de puericul tura, no Estado de São Paulo. Em 1941, sob intervenção de Fernando Costa, cuja filha, presidia a LBA - SP, O governo doa àquela entidade "... dez milhões de cruzeiros para cons trução de 80 postos de puericultura, estando em funcionamento, em 1947, 60 unidades ... (MORAIS, 1947:16). Ressalta-se, novamente, a relação entre entidades civis e aparelho esta tal não só em termos diretivos; da direção regional da LBA, um de seus diretores era um representante do Departamento Es

(18) Fundada por Darcy Vargas para amparar as familias de soldados convo cados para guerra, ampliando sua atuação com atendimento a velhos inválidos, tuberculosos, mães solteiras, recém-nascidos desamparados (MORAIS, 1947) e, em 1974, é incorporada ao Ministério da Previdéncia e Assistencia Social. 
tadual de Criança.

"Sociedade civil, possuindo recursos de 1 milhão e oitocentos mil cruzeiros mensais para serem empregados sem entraves burocráticos ou injunções externas ..." (MORAIS, 1947:16) estabelecerá, em 1953,convênio com secretaria da Saúde pública e Assistēncia Social e em 1957, com auxílios extraordinários subvencionará os postos de puericultura vo lante (LBA, 1957).

Alēm de instalação de unidades, a LBA será respon sável pelo fornecimento de leite e/ou auxílios financeiros. Em 1947, no Interior, de uma verba mensal de $\operatorname{Cr} \$ 782.000,00,7,67 \%$ eram gastos no fornecimento de leite aos postos de puericultura, sendo o restante dispendido em sopa escolar e auxilio às instituições (MORAIS, 1947), observando-se que, nesta dis tribuição, os postos de puericultura de alguns municípios eram privilegiados; tanto na distribuição de leite como de auxí lios. Destacaram-se os municípios de Santos lespecificamente o Bairro de Macucol, Franca, Itapetininga, Campinas, Bau ru, Jacarei, Jaú, Marília, Avaré, Tietē, entre os 107 municí pios beneficiados (LBA, 1957).

E bastante provável que a distribuição obedecesse a interesses político-partidários, apesar de que, em 1947, estabelece-se que os presidentes das Comissões Municipais,li gados, provavelmente, ao Executivo Municipal, como se verifi ca em nível Estadual, deveriam "... ser elementos de mereci do prestígio local, de elevado caráter e de acentuado pendor pelos problemas assistenciais e manter-se eqtidistantes das paixões partidárias ..." (MORAIS, 1947:18), fenōmeno bastan 
te raro, nas disputas partidárias nas cidades interioranas e pela máquina estabelecida pelo PSP como já foi visto.

E evidente a participação do governo estadual e fe deral, na expansão dos serviços médicos-hospitalares de as sistência à maternidade e à infância. Em 27 de junhode 1951, pela Lei no 1091, a Secretaria da Fazenda é autorizada a abrir um crédito especial no valor de Cr $\$ 15.000 .000,00$ à Secretaria da Saúde para instalação de postos de puericultura e pos tos de puericultura volantes, assim como, para aquisição de veículos para estes últimos (D.0. 27.06.1951). Em 1952, são instalados 157 postos de puericultura e 16 postos de puericul tura volantes (D.O. 09.08.1952). Em 02 de janeiro de 1953,a Lei no 2128 estabelece a participação da Secretaria de Saúde, juntamente com a LBA e outras entidades públicas e privadas, na fundação de hospital destinado à criança, abrindo um cré dito especial junto à Secretaria de Fazenda para o mesmo fim No mesmo ano, é estabelecido convênio com a LBA regional pạ ra construção, instalação e manutenção de Postos de Puericul tura (D.O. 04.09.1953).

Provavelmente, a captação de recursos federais, as sim como seu repasse, faz com que o governo crie junto à se cretaria o Fundo de Proteção à Maternidade e Infāncia pelo Decretono 27.498, em 1957, (19) cujos objetivos eram:

(19) É provável que, a partir dessa data, tenham sido criados värios fun dos; em 1962, a Lei no 6864 regulamentou os Fundos Especiais e ainda não criados por Leis e, em 1966, a Lei no 9.303, de 15 de abril de 1966, em cumprimento à 1ei anterior, institui os Fundos Especiais, criados pelo Executivo e vinculados a Secretaria de Saude e Assistência Social (Fundo de Puericultura do Departamento Estadual da Criança; de Pesquisa do Departamento de Assistência aos Psicopatas e Fundo de Proteção à Maternidade e Infäncia e, posteriormente, ou tros). 
" - promover acordos ou estabelecer contratos com entidades privadas para ampliação de suas atividạ des;

- contribuir para ampliação e melhoria das instala ções e aparelhamento dos örgãos dos serviços püblí cos ou de instituições particulares que tinham por finalidade a assistência à maternidade e infância ..." (D.0. 20.02.1957).

Entre 1957/1958, surgem inúmeros decretos para in talação de postos de puericultura, decrescendo o número de decretos, com esta finalidade a partir de 1960.

A Tabela 13 mostra o número de postos de puericultura, observando-se um aumento um pouco maior na Capital, en tre 1955/57, invertendo esta posição nos dois anos seguintes e inclusive a diferença, aumento maior de postos no Interior. Em 1965, o número de postos é praticamente semelhante, privi legiando, como se verá, os postos de assistência médica.

TABELA 13 - Número de postos de puericultura, por área, Estâ do de São Paulo, 1955/1959 e 1965

\begin{tabular}{crcc}
\hline Area & Capital & Interior & Total* \\
\hline 1955 & 8 & 248 & 256 \\
1956 & 52 & 278 & 329 \\
1957 & 95 & 309 & 404 \\
1958 & 114 & 417 & 531 \\
1959 & 112 & 452 & 564 \\
$\ldots$. & & & 556 \\
\hline 1965 & 128 & 428 & 56 \\
\hline
\end{tabular}

* Excluidos os postos volantes

FONTE: CARLOS (1960:42), LEMOS (1967) 
Segundo CARLOS (1960:42) "... as verbas destina das ao Departamento Estadual da Criança - (DEC) - foram apro ximadamente de $\operatorname{Cr} \$ 152.000 .000,00$, em 1955, para num crescen do, atingir perto de $\operatorname{Cr} \$ 460.000 .000,00$, em 1959 ...",provavelmente, em decorrência do convênio com a Comissão Regional da LBA para instalação, construção e manutenção de 100 pos tos de puericultura (D.O. 15.01.1958). Como assinala o au tor "... a assistēncia à infância, tanto médica como alimen tar, foram intensificados, havendo incentivo das vacinações anti-varíola, antidiftērica, Salk e outras, assim como uma grande campanha de combate à desidratação ... Por outro la do, a assistēncia alimentar compreendeu farta distribuição de leite, tanto fresco, como principalmente em pó ..." (CARLOS, 1960:42), permitindo, portanto, o acesso a alguns bens de consumo, que passam a ser produzidos, no Brasil, ou mesmo im portados como vacinas. Em 1950, foram distribuías 66.149 latas de leite em pó, em 1955, 504.179 passando para 1.525.452 em 1959, além de 1.245.422 litros de leite fresco (MONETTI \& SOUTO, $1960: 299)$.

Segundo L'ABBATE $(1982: 52)$ "... os programas de ajuda alimentar estabelecidos através de alguns organismos da ONU, como a FAO e a UNICEF, prestam-se, também como afirma Paulette Goldenberg, para o escoamento dos excedentes da produção do Canadá e Estados Unidos, que haviam alcançado grande desenvolvimento agrícola, a partir da Revolução Verde Esses programas ganham maior expressão entre 1950 e 1960 e, em 1954, através da "Lei dos Alimentos para Paz", os Estados Unidos passam a regulamentar essas "doações..." 
E interessante notar que altas taxas de mortalidade infantil, prevalentes desde o início do século, começam a decair, acentuadamente, a partir dos meados da década de 40, Tabela 14 e especificamente, no municipio de São Paulo, onde - número de postos de puericultura sempre foi menor. Este fe nômeno leva a considerar outros fatores a serem investiga dos, uma vez que as campanhas de vacinação só ocorrerão, a partir da década de 60 , como se verá posteriormente, quando as taxas apresentam, novamente, uma tendência crescente até meados da década de 70, declinando a partir de então, com uma taxa em torno de 57 por 1000 nascidos vivos, em 1979.

Dados disponíveis sobre o salário mínimo real no Brasil, Tabela 15, demonstram que, em relação a 1963, ele decresceu no período 1952 a 1954 e ao elevar-se, apresentou oscilações sendo que, entre 1959 e 1961, atinge seu ponto mais alto, decrescendo, a partir de então, a níveis mais baixos do que àqueles apresentados, em 1952, deflagrando uma série de movimentos grevistas, como se verá

Segundo DUARTE (apud HOFFMANN, 1975:108) entre 1960/70, "... metade da população não foi atingida pelos be nefícios do crescimento econômico (em termos monetários) e outros $30 \%$ tiveram acesso apenas marginal a estes beneficios ..." No mesmo período enquanto 50\% da população de renda mais baixa tiveram um aumento percentual da renda média do estrato de 18 ; os $5 \%$ da população de renda mais alta tiveram um aumento de $72 \%$. 
TABELA 14 - Taxas de mortalidade infantil, Município e Estą do de São Paulo, Interior 1930/1979

Anos Municipio Interior Estado Anos Municipio Interior Estado

O C O R R E N C I A

\begin{tabular}{|c|c|c|c|c|c|c|c|}
\hline 1930 & 192,63 & 170,42 & 167,87 & 1955 & 86,51 & 107,37 & 102,18 \\
\hline 1931 & 140,32 & 170,14 & 168,83 & 1956 & 86,38 & 103,81 & 99,38 \\
\hline 1932 & 140,79 & 167,43 & 163,75 & 1957 & 75,54 & 96,49 & 91,12 \\
\hline 1933 & 149,22 & 186,17 & 183,97 & 1958 & 70,21 & 95,19 & 88,72 \\
\hline 1934 & 141,29 & 183,89 & 178,13 & 1959 & 65,42 & 88,36 & 82,34 \\
\hline 1935 & 147,83 & 179,35 & 174,93 & 1960 & 62,94 & 82,55 & 77,17 \\
\hline 1936 & 137,80 & 193,48 & 188,48 & 1961 & 60,21 & 83,20 & 76,20 \\
\hline 1937 & 134,39 & 177,64 & 171,54 & 1962 & 64,42 & 81,01 & 76,20 \\
\hline 1938 & 138,18 & 171,04 & 166,56 & 1963 & 69,90 & 82,27 & 78,71 \\
\hline 1939 & 142,65 & 175,45 & 170,85 & 1964 & 67,75 & 71,79 & 70,60 \\
\hline 1949 & 123,99 & 187,51 & 178,30 & 1965 & 69,38 & 73,89 & 72,58 \\
\hline 1941 & 135,12 & 182,44 & 175,03 & 1966 & 73,80 & 76,74 & 75,86 \\
\hline 1942 & 121,53 & 149,09 & 140,23 & 1967 & 74,30 & 76,09 & 75,58 \\
\hline 1943 & 125,37 & 147,71 & 142,94 & 1968 & 76,61 & 72,40 & 73,67 \\
\hline 1944 & 123,79 & 154,97 & 148,53 & 1969 & 84,50 & 83,15 & 83,57 \\
\hline 1945 & 101,49 & 138,53 & 132,60 & 1970 & 89,52 & 81,87 & 84,34 \\
\hline 1946 & 79,78 & 115,83 & 109,78 & \multicolumn{4}{|c|}{ RE S I D E N C I A } \\
\hline 1947 & 40,12 & 112,11 & 106,11 & 1971 & 85,38 & 92,30 & 90,07 \\
\hline 1948 & 87,85 & 123,58 & 116,81 & 1972 & 85,66 & 86,38 & 86,15 \\
\hline 1949 & 50,64 & 119,14 & 113,96 & 1973 & 87,20 & 90,15 & 89,17 \\
\hline 1950 & 49,71 & 122,45 & 115,85 & 1974 & 78,03 & 84,55 & 82,33 \\
\hline 1951 & 71,47 & 119,75 & 113,70 & 1975 & 79,96 & 87,99 & 85,24 \\
\hline 1952 & 71,00 & 114,00 & 104,39 & 1976 & 74,81 & 78,45 & 77,20 \\
\hline 1953 & 79,16 & 111,20 & 103,77 & 1977 & 66,52 & 69,90 & 68,79 \\
\hline \multirow[t]{2}{*}{1954} & 74,72 & 102,16 & 95,41 & 1978 & 54,28 & 65,75 & 75,25 \\
\hline & & & & 1979 & 57,88 & 54,44 & 58,46 \\
\hline
\end{tabular}

FONTE: GIRALDELLI (1983:87). 
TABELA 15 - Salārio mínimo real médio - nümeros índices(1963 =100), Brasil, $1952-1981$

\begin{tabular}{lccc}
\hline A n o & $\begin{array}{c}\text { Salário mínimo } \\
\text { real médio }\end{array}$ & A n o & $\begin{array}{c}\text { Salário mínimo } \\
\text { real médio }\end{array}$ \\
\hline 1952 & 90 & 1967 & 82 \\
1953 & 79 & 1968 & 83 \\
1954 & 94 & 1969 & 81 \\
1955 & 105 & 1970 & 79 \\
1956 & 106 & 1971 & 79 \\
1957 & 117 & 1972 & 81 \\
1958 & 102 & 1973 & 84 \\
1959 & 117 & 1974 & 79 \\
1960 & 105 & 1975 & 83 \\
1961 & 120 & 1976 & 84 \\
1962 & 109 & 1977 & 84 \\
1963 & 100 & 1978 & 84 \\
1964 & 101 & 1979 & 84 \\
1965 & 93 & 1980 & 86 \\
1966 & 86 & 1981 & 85 \\
\hline
\end{tabular}

FONTE: SERRA (1982a:63).

Na mesma dēcada, ampliam-se as campanhas de vacina ção, em decorrência da Carta de Punta del Este (MONETTI et alii, 1974). Em 1961, "... com a contribuição da OPAS que forneceu de 25 a $62 \mathrm{mil}$ doses, foi desencadeada a "Operação Santo André" (Arq. Hig., 1962a), realizando-se um plano pilo to de vacinação contra a poliomielite, no Brasil e que ser viu "... também para avaliação dos testes imunitários conferidos pela vacina" (CARLOS, 1962:76). Deve-se ressaltar que, conforme nota MILANO et alii (1962:208), Santo André era ".. lugar de grande destaque no parque industrial paulista 
...", com concentração de indústrias de ponta. A "Operação Santo André seguiu-se a "Operação Capital", anteriormente pre cedida da vacinação dos municípios de são Bernardo, São Caetano, Mauá, Ribeirão Pires e Diadema, também áreas industriais (Arq. Hig., 1962a). No segundo semestre, do mesmo ano, procedeu-se à vacinação no interior de são Paulo (PRADO, $1962)$.

Segundo MONETTI et alii (1974:27) iniciou-se em 1966, a título experimental, no ex-Instituto de Puericultura, a vacinação contra sarampo e em 1967, institucionalizava-se a Campanha de Erradicação da Varíola, acrescidas das atividades de vacinação já desenvolvidas pelos Postos de Puericultụ ra, pois, como notam os AAs acima referidos, pelo menos com relação à tríplice (Difteria, Tétano e Coqueluche), até 1963, "... as vacinas eram ministradas quase exclusivamente pelas unidades assistenciais (Postos de Puericultura) do extinto Departamento Estadual da Criança, passando a partir de então serem ministradas pelos Serviços de Centros Saúde da Capital e, em 1968, em todas as unidades ..." E provável que a expansão dos Postos de Puericultura tenha suprido as deficiên cias, assinaladas por MASCARENHAS (1949) para o período de 1942/1945, referentes ao número de.pessoal e às dificuldades de meios de transporte. Contudo, MONETTI \& CARVALHO (1975: 116) afirmam "... que apesar das moléstias infecciosas e pa rasitárias apresentarem um declínio entre 1960/70, esse dẹ clínio não foi tão sensivel como seria de se esperar, face aos programas e campanhas de vacinação desenvolvidos pela se cretaria do Estado de Saúde ..." 
As principais causas de mortalidade infantil, em 1951, estão apresentadas na Tabela 16, observando-se o predọ minio da mortalidade por debilidade congênitas, 39,8\% do to tal, incluindo, provavelmente, as causas decorrentes de par to e puerpério; as doenças infecciosas e parasitárias, con tribuiam com apenas $5,4 \%$, enquanto as perturbações nutritivas provavelmente decorrentes da desnutrição, 14,1\%.

TABELA 16 - Coeficientes de mortalidade infantil/1000 nasci dos vivos, segundo doença e porcentagem do total. Estado de são Paulo, 1951

\begin{tabular}{|c|c|c|}
\hline \multirow[b]{2}{*}{$\mathrm{D} \circ \mathrm{e} \mathrm{n} \mathrm{c} a$} & Coef./100 & \multirow{2}{*}{$\begin{array}{l}\text { \% do } \\
\text { Total }\end{array}$} \\
\hline & Nascidos vivos & \\
\hline Debilidade congēnita & 41,91 & 39,8 \\
\hline $\begin{array}{l}\text { Perturbações nutritivas (exceto } \\
\text { inadaptação ao regime alimentar) }\end{array}$ & 14,92 & 14,1 \\
\hline $\begin{array}{l}\text { Diarréia e enterite (exceto diar } \\
\text { réia dos recēm-nascidos) }\end{array}$ & 10,25 & 9,7 \\
\hline $\begin{array}{l}\text { Doença do aparelho respiratório } \\
\text { (exceto pneumonia dos recém-nas } \\
\text { cidos) }\end{array}$ & 9,69 & 9,2 \\
\hline $\begin{array}{l}\text { Doenças infecciosas e parasitä- } \\
\text { rias (exceto o item 768) }\end{array}$ & 5,66 & 5,4 \\
\hline Tétano umbelical & 3,99 & 3,8 \\
\hline
\end{tabular}

FONTE: FERREIRA \& SALUM $(1953: 257)$.

Entre 1960/61, o coeficiente de mortalidade por doenças infecciosas e parasitárias permanece quase no mesmo nível de 1951, 5,05 por 1000 nascidos vivos, decrescendo pa ra 3,36 em 1971 e, em diferentes graus para difteria, tétano, coqueluche, poliomielite, variola, Tabela 17. 
TABELA 17 - Coeficientes de mortalidade infantil por mil nas cidos vivos, segundo principais causas de doença, Estado de São Paulo 1960/61, 1970/71

\begin{tabular}{|c|c|c|c|}
\hline $\begin{array}{l}\text { Moléstias } \\
\text { (7ạ Revisão - 1959) }\end{array}$ & $\begin{array}{l}\text { Ano } 1960 / 61 \\
\text { Estado }\end{array}$ & $\begin{array}{l}\text { Moléstias } \\
\text { (8å Revisão-1965) }\end{array}$ & $\begin{array}{c}\text { Ano } 1970 / 71 \\
\text { Estado }\end{array}$ \\
\hline Tétano & 2,40 & Septicemia & 1,27 \\
\hline Disenteria & 0,63 & Tétano & 0,57 \\
\hline Sarampo & 0,51 & Sarampo & 0,49 \\
\hline Coqueluche & 0,30 & Coqueluche & 0,15 \\
\hline Sifilis & 0,25 & Disenteria & 0,09 \\
\hline Poliomielite & 0,18 & Poliomielite & 0,07 \\
\hline Tuberculose & 0,14 & Difteria & 0,05 \\
\hline Difteria & 0,12 & Varicela & 0,05 \\
\hline Inf. meningocócicas & 0,07 & Tuberc. pulmonar & 0,03 \\
\hline $\begin{array}{l}\text { Encefalite Infec. } \\
\text { aguda }\end{array}$ & 0,05 & $\begin{array}{l}\text { Tuber.das meninges } \\
\text { e do s.n. central }\end{array}$ & 0,03 \\
\hline Variola & 0,01 & & \\
\hline $\begin{array}{l}\text { Outras doenças } \\
\text { infec. e parasit. }\end{array}$ & 0,38 & $\begin{array}{l}\text { Outras doenças } \\
\text { infec. e parasit. }\end{array}$ & 0,57 \\
\hline $\mathrm{T} O \mathrm{TA} \mathrm{A}$ & 5,05 & $\mathrm{~T} O \mathrm{~T} A \mathrm{~L}$ & 3,36 \\
\hline
\end{tabular}

FONTE: MONETTI \& CARVALHO (1975:143).

Entretanto, continuam predominando, e com sensivel aumento nos dois biênios, as gastrenterites com participação de 21 a.27\% dos óbitos; as causas perinatais, de 22 a $24 \%$ e as doenças do aparelho respiratório, de 17 a $21 \%$. Entre 1970/71, continuam predominando os óbitos infantis, causados por aquelas doenças mais diretamente associadas às condições de alimentação, à habitação e assistência médica, conforme Tabela 18. Observa-se, também, a elevação destes coeficien tes entre $1960 / 61$ e $1970 / 71$. 
TABELA 18 - Coeficientes médios de mortalidade infantil, por mil nascidos vivos, por principais grupos de mo léstias, Estado de São Paulo, 1960/61 e 1970/71

\begin{tabular}{|c|c|c|c|c|c|c|}
\hline \multirow{2}{*}{ Grupos de Causas } & \multicolumn{3}{|c|}{$1960 / 61$} & \multicolumn{3}{|c|}{$1970 / 71$} \\
\hline & Capital & Interior & Estado & Capital & Interior & Estado \\
\hline Gastrenterites $(*)$ & 12,24 & 17,45 & 16,01 & 20,31 & 24,72 & 23,29 \\
\hline Perinatais (*) & 18,02 & 16,18 & 16,69 & 19,43 & 21,17 & 20,60 \\
\hline Mol.do ap. respirat. & 16,02 & 12,01 & 13,12 & 19,62 & 17,23 & 18,02 \\
\hline Anomalias cong. $(* *)$ & 4,48 & 2,31 & 2,90 & 3,94 & 3,50 & 3,64 \\
\hline Mol.infec.paras. $(* \star *)$ & 4,17 & 5,39 & 5,05 & 3,67 & 3,21 & 3,36 \\
\hline Outras & 6,63 & 29,54 & 23,23 & 12,61 & 19,57 & 17,29 \\
\hline $\mathrm{T} O \mathrm{~T} A \mathrm{~L}$ & 61,57 & 82,89 & 77,01 & 79,60 & 89,43 & 86,21 \\
\hline
\end{tabular}

OBS.: (*) Inclui as gastrenterites e colites de 1960/61 e doenças diar rëicas de 1970/71.

(**) Nos anos $1960 / 61$, as anomalias congênitas e a sifilis foram deduzidas de causas pré-natais, natais e neonatais.

$(* * *)$ Foram, incluidos os casos de sifilis de $1960 / 61$ e excluidas as doenças diarréicas de 1970/71.

FONTE: MONETTI \& CARVALHO (1975:142).

Dentre as moléstias infecciosas, são as gastroente rites que aparecem como principal causa de óbito, tambēm, nos grupos etärios de 1 a 14 anos, sendo os coeficientes médios, para os grupos etários de 1 a 4,5 a 9 e 10 a 14 , respectiva mente, $163,4,6,43,2,13 / 100.000$ habitantes no periodo de 1960/61 (MONETTI \& CARVALHO, 1975).

E interessante observar a tendência verificada nos últimos anos, com relação à mortalidade infantil, onde o "... risco de morte durante o primeiro dia de vida teve uma queda reduzida, entre 1940 a 1979 , especialmente se compara- 
da com as outras idades. Nestes 30 anos, a taxade mortalida de no primeiro dia de vida apresenta uma queda de apenas 13\%, enquanto a mortalidade correspondente a 1 - 6 dias conseguiu reduzir-se em quase 50 o e a ocorrida entre 7 - 27 dias de ví da em mais de 70\%, Tabela 19. A redução no grupo de 6 a 11 meses foi de 85잉 (ORTIZ, 1983:97), modificando a estrutura de mortalidade infantil, segundo idade, ressaltando, ainda, que, após 1964, ocorreu uma expansão da assistência médica hospitalar.

TABELA 19 - Tendência da mortalidade infantil, segundo idade, Estado de São Paulo 1940/1979

\begin{tabular}{rrrrrrrrrrr}
\hline \multirow{2}{*}{ Idade } & \multicolumn{7}{c}{ Taxas } & \multicolumn{7}{c}{ de mortalidade infantil } \\
\cline { 2 - 10 } & 1940 & 1945 & 1950 & 1955 & 1960 & 1965 & 1970 & 1975 & 1979 \\
\hline 0 dia & 10,14 & 8,89 & 7,72 & 7,97 & 8,74 & 9,18 & 10,10 & 10,19 & 8,82 \\
$1-6$ dias & 19,82 & 16,71 & 14,79 & 13,67 & 12,31 & 12,87 & 13,83 & 12,44 & 10,45 \\
$7-27$ dias & 31,98 & 25,91 & 20,33 & 16,57 & 13,06 & 12,06 & 15,52 & 13,02 & 8,79 \\
28 dias & 61,94 & 51,51 & 42,84 & 38,22 & 34,11 & 34,11 & 39,44 & 35,65 & 28,06 \\
$1-5$ meses & 65,22 & 48,06 & 44,85 & 42,38 & 29,00 & 26,84 & 32,48 & 37,27 & 23,02 \\
$6-11$ meses & 51,14 & 33,03 & 28,16 & 21,58 & 14,07 & 11,63 & 11,26 & 11,71 & 7,08
\end{tabular}

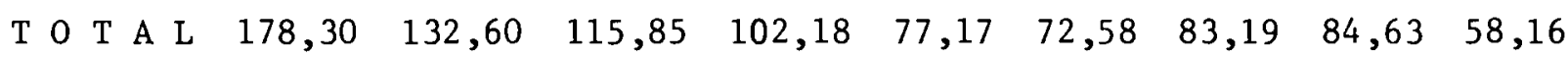

FONTE: ORTIZ (1983:96)

RAMOS (1951:35, 36) assim se referia sobre a ques tão da mortalidade infantil e os serviços de proteção à in fância.

"Todo esse vasto mecanismo se edificou sobre um falso pressuposto o de que o problema da mortalida 
de infantil comporta uma solução médica ... os ór gãos nacionais e estaduais de proteção a infância vivem desse ideal ..." (o de proporcionar assistên cia médica a todas as crianças doentes) "... Não há dūvida de que tratar uma criança doente é um problema médico. Todavia, tratar uma população גma massa de indivíduos doentes, deixa de ser um problema médico - é um problema social. E se é um problema social, sua solução é social, isto é, im plica menos em uma distribuição de conselhos, de remédios, ou de alimentos do que a transformaçãode todo um complexo institucional ... o vício fundamental do nosso sistema administrativo de proteção à infāncia laliás como todo nosso sistema sanitā rio) consiste em que ele aplica, no tratamento de um problema de massa, os mesmos processos de medicina individual. Em resumo, eles, os dirigentes do sistema "... não assimilaram ainda a idéia de planificação ..." que se impunha frente "... às crescentes responsabilidades a que o Estado vinha assumindo ... para uma aplicação mais produtiva dos recursos orçamentários e, frente à falta de base econômica para suportar os gastos orçamentários atuais com medidas de assistēncia médico-sanita rista. ..."

Para que "... a administração pública ultrapassas se a presente fase do laissez-faire e entre numa fase de pla nificação, é necessārio toda uma mudança de estilo. Quero 
dizer, é necessário adestrar os administradores numa nova ma neira de pensar. Reeducá-los ... uma vez que o nosso sistema federal de órgãos de proteção à infância continua ainda, do ponto de vista faseológico, numa etapa filantrópica e utó pica ao problema da mortalidade infantil ... de campanhas, cruzadas, batalhas, que se mantēm às custas de pessoas generosas ..." (RAMOS, 1951:37, 39).

Ainda, chama a atenção para o fato de que "... a renovação de métodos, cuja urgência é reconhecida pelos me lhores elementos de carreiras técnicas dos serviços de assis tência médica, esbarra em situações cristalizadas e interesses investidos, que impedem a sua efetivação. Tudo indica existir, na organização médica-sanitária do país uma compene tração de interesses públicos e particulares muito conscien tes de si mesmos e dispostos a esmagar implacavelmente quem quer que ouse contrariá-los ..." (RAMOS, 1951:41).

Esta afirmativa parece ser verdadeira, uma vez que - DEC, constituído no final do Estado Novo, ampliou suas uni dades na década de 50, como já foi visto e possibilitou,atra vés do estabelecimento de Fundo e de convênios, a "compenetra ção de interesses públicos e privados". Este fato, parece motivar a designação, em 1968, "... de uma médica para fisca lizar os convēnios entre o DEC e as instituições hospitalares destinadas à maternidade e infância." (D.O. 12.07.1968). Mas, também, corresponde a diferentes interesses dentro secreta ria que, no final da década de 50 e na década de 60 , expandi rá outros tipos de unidades, os sub-postos e postos de assis tēncia médica social. 
As propostas de assistência médica-social

rural ressurgem, em meados da década de 40, com a preocupação dos sanitaristas no controle de endemias rurais e na organização de unidades agromédico-sociais para o atendimento da população rural dentro da concepção de desenvolvimento comunitário, na qual a educação teria um papel fundamental, assim como a contribuição das ciēncias sociais (20), como escreve PASCALE (1953:4):

"... Para que se possa, porém, elevar o nível so cial das populações rurais é mister "avançar no sen tido do bem estar comum", através de um trabalho perseverante e persuasivo de aceitação dos progres sos realizados pela vida urbana, sem a quebra vio lenta das resistências e inadequados. Sem a preocupação de tais cautelas, dificilmente se poderá concretizar o ideal da organização das comunidades rurais e do desenvolvimento da liderança sob qual tais comunidades deverão agir ... A institui ção de uma "política de ataque aos nossos problemas rurais", orientada pela sociologia, implicará, fatalmente, na adoção de normas de conduta e de no vas técnicas consentâneas com a expansão paulatina das conquistas do progresso humano a fim de que, tornando-se permeáveis às novas bases de conduta,

(20) E interessante notar as relações entre o Instituto de Higiene e Escola de Sociologia e Política, ambas instituiçóes instaladas com a colaboração da Fundação Rockfeller, sendo um dos signatários para importanncia dessa instalação Geraldo de Paula Souza, ' conforme BERLINCK (1958). TRUJILLO (1958) nota a influência da Escola nos trabalhos de alguns sanitaristas como Mascarenhas e Lesere; o pri meiro inclusive, aluno e, posteriormente, professor daquela Escola (MASCARENHAS, 1949). 
adquiram melhores hábitos higiênicos, modernos no ções de preservação e de recuperação da saúde, as similem métodos racionais de trabalho, incorporem novas e mais perfeitas normas de convivência ..."

As unidades agro-médico-sociais, resultantes do Ponto IV, anteriormente referido, e estabelecido pelo Decre to no 21522 de 01 de julho de 1952, tinham a finalidade de "... promover a fixação do homem rural através de um serviço de assistência agro-médico-social, visando a elevação do pạ drão cultural e econômico bem como dos indices de saúde das populações rurais ..." (D.O. 02.07.1952). Essas propostas de atenção à área rural sedimentam, inclusive com a Lei no 2743, de 06 de março de 1956, que institui, no Ministério da Saúde, o Departamento Nacional de Endemias Rurais - DENERU e se associam a ocupação a região centro-oeste do Brasil. As atividades, essencialmente educativas, desenvolver-se-iam nas escolas com a criação de centros sociais-rurais, cujas ações caberiam a uma equipe multiprofissional de médicos, agronō mos, educadoras sanitārias, dentistas, enfermeiras e professo ras, recebendo colaboração da American Internation Association.

Dentro desta perspectica de atenção rural, em 1958, é realizado no Estado de São Paulo, "... um levantamento de recursos disponíveis, inclusive com colaboração das Prefeitú ras e fazendas que possuem serviços médicos particulares (21) a fim de estabelecer um vasto programa de assistência médico

(21) Segundo PESSOA (1960), a assistēncia médica privada na zona rural compreendia: 1) assalariamento, em grandes propriedades agrícolas; 2) sistema de contrato, em zonas cafeeira, onde o médico recebe con tribuição por familia de colono, pés de café; 3) caixa, os colonos contribuem mensalmente com determinada quantia, gerida por um administrador. 
sanitário às populações rurais ..." (D.0. 24.05.1958). Essa proposta advém da reunião de Delegados de Saúde, em Marília, para discutir problemas relacionados, além da assistēncia mé dico-sanitária às populações rurais, ao combate a esquistossomose e à participação da engenharia sanitária nos progra mas estaduais.

No mesmo ano, é criada junto ao Gabinete do Secretário, uma Comissão Especial de Combate à Moléstia de Chagas que "... acarreta, anualmente, grande número de vítimas no seio da população rural." Pelo Decreto no 30.789, é estabelecida a composição de pessoal (elementos do Serviço de Profilaxia da Malária, oficiais da força pública) e os recursos, em termos materiais, das diferentes Secretarias de Estado,além da Saúde (Agricultura, Educação, Segurança Pública e Viação e Obras Públicas) e, em termos financeiros, verbas do Serviço de Profilaxia da Malária, suplementadas por créditos da Secretaria da Fazenda (D.0. 31.01.1958).

Na mesma época, a Secretaria empenha-se na erradica ção da malāria atravēs de convēnio com órgãos federais e in ternacionais. Em 1958, é estabelecido convênio entre União, Estado, OMS e a International Cooperation Association (Ponto IV) através do qual este órgão forneceria veículos, peças e acessórios, solventes e emulsificantes, equipamentos para rociamento (CARVALHO PINTO, 1959; MELLO, 1960), promovendo, inclusive, reunião de Delegados (D.O. 04.02.1958). De acordo com o convênio, a Secretaria recebeu 2 milhões e $140 \mathrm{mil}$ comprimidos de Aralen (D.O. 19.07.1958).

Por outro lado, a falta de recursos e de estrutura 
institucional para controle de Chagas, faz com que a Secreta ria recorra à criação de Ligas de Combate à Moléstia de Cha gas, tentando mobilizar "... autoridades federais,municipais, estaduais, religiosas,militares, médicos, diretores e profes sores de ensino, fazendeiros, sitiantes, industriais, líde res de comunidade e todos aqueles que se interessam pelo pro blema ..." (D.O. 25.05.1958). De um lado, essas ligas promo veriam o Cadastro de todas as casas de-pau-a pique, auxiliariam com mão-de-obra e matéria-prima para o revestimento de casas que o necessitassem e promoveriam a extinção daquelas casas, a serem substituídas por habitações imunes aos barbei ros. Por outro lado, a Comissão Especial de Combate à Molés tia de Chagas responsabilizar-se-ia pela demonstração de pro cessos de impermeabilização, aplicação do inseticida (BHC) e fornecimento de aparelhamento para revestimento das casas, além da educação sanitária e de prêmios anuais aos que se destacassem, cabendo ao primeiro colocado o Troféu "Carlos Chagas" e ao segundo, Prêmio "Oswaldo Cruz" (D.0. 25.05.1958). Diante da falta de recursos, em 1959, propõe-se convēnio com - DENERU para auxilios financeiros (D.0. 17.05.1959).

No mesmo ano, 1958, são criadas outras duas Comis sões Especiais: a de Combate à Esquistossomose e de Planejamento e Coordenação da vacinação BCG, comissões estas que, em 1968, passam a ser institucionalizadas e transformam-se em Campanha contra Combate à Esquistossomose (CACESQ) e Fundo de Educação Sanitária e Imunização em Massa contra Doenças Transmissiveis (FESIMA).

Devem-se ressaltar os determinantes econōmicos na 
importância das duas Comissões. A CACESQ surge dada a alta freqtência da esquistossomose no litoral e no planalto (D.O. 09.04.1958), especificamente Vale do Paraíba, locais em que se expandem, a partir de 1956, os novos ramos industriais de produção de bens de capital (máquinas e equipamentos) e bens intermediários (siderúrgica, produtos químicos), dentro do processo de substituição de importação (SINGER, 1973).

A FESIMA resulta da recomendação da OPS ao "... go verno federal que institui, em 1966, no Ministério da Saúde, a Campanha de Erradicação da Variola ... Coordenando os seus esforços com os do governo federal e da OPS, o governo do Estado criou, por força do Decreto no 40.021 de 30 de novembro de 1967, a Campanha de Erradicação da Varíola (CEV) no Estado de São Paulo ..." Em 08 de maio de 1968, instituiu-se a FEsIMA, "... com o objetivo de custear com seus recursos orçamentários os programas de imunização em massa na secreta ria, entre os quais, em primeiro plano, por seu vulto, se destaca a CEV (SOARES, 1971:1).

Tanto a CACESQ Como a FESIMA parecem representar um outro momento de composição de forças dentro da Secretaria e que se inicia na década de 60. Até esta data, os dados pare cem indicar a disputa entre três āreas tradicionais Iepra, tuberculose, e materno-infantil. O anteprojeto de Reforma da Secretaria, apresentado em 1957, reduzia, de certa maneira, as três áreas, a medida que suas unidades estariam engloba das numa ünica unidade, o Departamento de Unidades Sanitárias ficando suas unidades hospitalares situadas no Departamento de Assistēncia Hospitalar. (SSPAS, 1957). 
Na década de 60 predominam as leis, criando subpos tos de saúde, de assistência médico-sanitária e postos de assistência médica sanitária (22), o que parece indicar o deslocamento de forças dentro da Secretaria. Neste sentido, são oportunas as afirmações de LEMOS $(1967: 35,36)$.

"No atual sistema de composição de forças partidárias heterogeneas, as Secretarias, quase sempre nascem dos conchavos e imposições politicas constí tuindo; o preço, em alguns casos onerosíssimos que - governo paga pelas adesões das respectivas legen das ao bloco situacionista da Assembléia Legislati va ... A Pasta da Saúde, loteada entre políticos e administradores converteu-se, hoje, em verdadei ro mosaico de pequenas, secretarias, constituidas de órgãos autônomos, com seus próprios mecanismos administrativos ..."

Porém, a expansão dos serviços de saúde pública,le galmente decretada, deve ser vista com ressalvas. Criados e ampliadas com base em créditos especiais ou de recursos fe derais, a infra-estrutura era bastante precāria; grande par te das unidades sanitárias, ainda em 1967, funcionava em ca sas alugadas, como demonstram as despesas com pagamento de aluguéis. (D.0. 4, 5, 8.03.1953, 06.03.1958, 24.03.1959, $03.03 .1960,18.05 .1965,10.03 .1966,07.07 .1967)$; quanto

(22) Em 1959, excluindo-se Dispensários, Postos ou Sub-Postos de Pueri cultura o Departamento de Saúde do Estado, contava com 446 Unidades Sanitärias, no Interior e na Capital, dispunha de 14 Centros de Saū de, 17 Sub-Centros de Saúde e 4 Centros de Assisténcia-Sanitária-Sö cial (Hospital das Clínicas da Faculdade de Medicina da U.S.P., Indicador de Instituição de Previdēncia Social e obras de Assistência Médico-Social de São Paulo, 2a edição, 1959, p. 144). 
aos recursos humanos, os servidores existentes excediam o "... número fixado e necessārio para lotação nas leis, decre tos, atos e normas, inclusive ocupantes de funções não prẹ vistas e dispensáveis, enquanto, em outras falta pessoal." (D.0. 07.11.1966). Em 1958, o Decreto no 32.066 dispunha que "... nos postos de puericultura onde existem em exercício es criturārios ou práticos de laboratório não será permitida a lotação de atendente ou auxiliar de dietética." (D.0.06.05. 1958) e, provavelmente, aqueles preenchiam as funções destas últimas.

Além deste excesso e/ou falta de pessoal, os servi ços de saúde ainda contavam com funcionários que residiam fó ra dos municípios onde exerciam o cargo (D.0. 08.04.1959, 07. 11.1966). Quanto à assistência médica, possivelmente era precária, uma vez que os consultantes

"... quase todos os médicos, por exemplo, em face aos baixos níveis salariais do serviço Público,pro curam em consultórios, empresas particulares ou em órgãos previdenciários, a suplementação de vencimentos de que precisam, mais compatível com a rele vância e a dignidade de seus encargos profissio nais ..." (LEMOS, 1967:51)

Estas características, contudo, não são especifí cas da Secretaria, mas das agências burocráticas estatais bra sileiros, como afirmava o Sr. Mario Beni, um dos líderes do PSP, "... Por que o governo o que é? E uma grande empresa onde tem colocação para muita gente ..." (CARDOSO, 1975:52)

A década de $1950 / 60$, porém, apresentará outras ques 
tões à Saúde pública paulista e que ela não conseguirá absor ver no seu quadro institucional.

Se as condições gerais se modificam rapidamente, com reflexo no quadro de mortalidade e morbidade, à Saúde Pública paulista são colocados outros problemas coletivos. E se, de um lado, não consegue controlar as doenças evitáveis para as quais dispōe de meios técnicos sem que haja altera ção nos outros setores (saneamento e assistência pré-natal, parto e puerpériol, por outro, não incorpora outros tipos de doenças, que atinge grande parcela da população, como as doenças cardíacas, provavelmente associadas a falta de con trole da Moléstia de Chagas, jā prevalentes entre as principais causas de óbito na década de 50 .

Estudos realizados, em 1950, demonstram que as responsáveis pela mortalidade eram, em ordem decrescente, doenças do aparelho circulatório, do aparelho digestivo e in fecciosas, exclusive tuberculose e sifilis, contribuindo, res pectivamente, com 13,9\%, 13,5\% e 7,3\% do total de óbitos (FERREIRA \& SALUM, 1953). Muito embora, 33,0\% do total de óbitos fossem classificados entre óbitos sem assistência mé dica e mal definidos, a predominância de doenças do aparelho circulatório é confirmada pelo menos, em duas cidades, São Paulo e Ribeirão Preto, pela Investigação Interamericana de Mortalidade Urbana, entre 1962/1963, (PUFFER \& GRIFFITH, 1968), cidades que estavam situadas nas Delegacias de Saúde onde haviam maior número de casos por aquelas doenças em 1950 (1377 a 1047 casos), sendo superada pela Delegacia de Saúde de Campinas (1578 casos), num total de 12.499 casos(FERREIRA 
\& SALUM, 1953). E muito embora, em 1959, seja proposta uma descentralização dos serviços do Instituto de Cardiologiafom a criação de 20 ambulatōrios especializados e prevendo-se a cons trução de um hospital especializado (CARLOS, 1958/1959).

Portanto, ao iniciar-se a década de 60 , a Saúde Pú blica defronta com uma problemática de saúde muito mais com plexa, advinda da intensidade do processos de urbanização e industrialização e da conseqthente mobilidade de massas populacionais, parcela das quais integra-se no mercado de trabaIho em expansão, enquanto outros constituiam-se nas chamadas "populações marginais", reservas excepcionais de força - detrabalho, problema esse que se agravaria mais se, parte des sa reserva não se deslocasse para as novas fronteiras agríco las da década de 1950/60, em direção ao Paranā.

Este conjunto de trabalhadores era caracterizado,pe la CEPAL, em três categorias, segundo sua participação ou não em sindicatos:

"1. setores populares sindicalizados - formados pe los operários que trabalham permanentemente em em presas grandes e médias. Em geral possuem certos graus minimos de qualificação e as suas condições de vida são superiores aos níveis de sub-consumo... "2. setores populares não sindicalizados - formados de operários que trabalham em tipo de pequenas em presas industriais e comerciais, oficinas, serviços de reparação, em construção e comércio ambulan te ... Apesar de sua variabilidade, em termos de condição de vida, em muito casos o seu nível de ví 
da está a baixo dos níveis de subconsumo.

"3. Setores populares em condições de "marginalidạ de" no conjunto esta categoria está formada por trabalhadores de escassa qualificação sem filiação sindical, que vivem abaixo dos niveis de subconsumo (IANNI, 1975:107, 108).

Aos setores populares, a SSPAS destina, através do Serviço Social "... assistência direta, nesta Capital ... e, nas Agências Regionais de Santos e Campinas ... realizou um intenso trabalho no Plano de Repressão a Falsa Mendicância e de Recuperação Social, na Capital e Santos ... gastando men salmente para pagamentos de pensões a indigentes e asilamentos ... tendo sido concedidos aparelhos ortopédicos" (BARROS, 1965:97)

Esse Plano, instalado como örgão oficial em 1960, "... estendeu a Campanha de repressão à Falsa mendicância e de Recuperação Social ao município de Santos e cidades ví zinhas ...", em 1961 (CÁRLOS, 1962:80). No ano de 1960; a SSPAS realizou-se um estudo para caracterizar esta população de mendigos, compreendendo 4.930 pessoas num total familiar de 12.527. Constatou-se que grande maioria era migrante do Norte e Nordeste e interior de são Paulo; possuindo alguns carteira profissional. Do total de 4.930, 69,4\% constituíam se de desocupados, $26,2 \%$ de trabalhadores rurais e o restan te compunha-se de ocupações diversas (JUNQUEIRA et alii, $1961: 281)$.

O agravante da situação dos trabalhadores, aliadas as suas condições de vida, é sua condição de trabalho, uma 
vez que o próprio processo produtivo industrial sofre profun das alterações pós-50, com a introdução de tecnologia, desen voldida nos paises centrais e extremamente predatórias às condições de saúde dos trabalhadores brasileiros.

A deterioração das condições de vida, em decorrên cia da queda salarial, suscita uma série de movimentos gre vistas entre 1953 a 1963. A partir do início de 1950, desen cadeou-se uma série de protestos - como as passeatas de"Panela Vazia" - e as paralisações de trabalho, que culminaram em São Paulo, com um movimento grevista semi-geral, conhecida como a Greve dos Trezentos Mil, iniciada no dia 26 de março de 1953 e que chegou a paralisar 276 empresas industriais; a greve alastrou-se para outras categorias, além dos operários téxteis apesar da oposição dos sindicatos, os ferroviários de Sorocaba, Bauru e Botucatu, tambēm, aderiram às greves, gre ve esta que marca a reconquista do direito de greve ao se opor ao Decreto Lei n\$9070 de 1946. A escalada inflacionária do governo Juscelino Kubitschek (1956-1961) detonou a greve dos quatrocentos mil; em outubro de 1957, coordenado pelo PIU (Pacto de Unidade Intersindical, formado em 1954) defla grou-se um movimento por uma coligação de sete sindicatos da capital, cujas reivindicações eram a extinção do Decreto-Lei no 9070, aumento salarial e medidas contra carestia (FGVCPDOC, 1984:1527-1537).

Limitada estruturalmente, sem condições de inter vir nas condições gerais de vida, a saúde pública paulista volta-se para seus problemas organizacionais pois, como res salta LEMOS (1967:55) "... Os que se responsabilizam pela ati 
vidades sanitárias do Estado concordam, sem restrições, que - maior problema da Secretaria da Saúde, em termos normais, não é o de recursos mas sim de aplicação adequada ...

Não dispomos de processos administrativos eficientes que nos permitam gastar bem, isto é, produzir o máximo com o mínimo de recursos, no menor espaço de tempo possível em proveito da comunidade ..."

Contudo, o mesmo autor afirmava que "... essas de ficiências administrativas dificultam a colaboração dos orga nismos internacionais na solução de alguns problemas prioritários ... não temos organização para receber ajuda financei ra ..." (LEMOS, 1957:56), ou seja faltava à secretaria os re cursos financeiros.

A colocação da necessidade de reforma da Secretaria no entanto, não era nova, assim como a formulação de planos de saúde e seu financiamento. A Secretaria de Saúde e Assis tência Social, criada em 1948, mantinha sua estrutura praticamente intacta e, apesar dos decretos sobre sua reestrutura ção, os anteprojetos apresentados não tinham o consenso das bancadas legislativas, uma vez que essa reestruturação, pro vavelmente, afetava os interesses do partido majoritário, co mo também, dos diferentes grupos burocráticos a ele ligados, dentro da Secretaria.

Porém, a idéia de uma racionalidade via planejamen to passa a vigorar, já na década de 50, no setor saúde, numa

(23) Palavras essas que reafirmarä ao assumir o Ministério de Saüde, em 1975, "... o problema fundamental da Saúde Pública no Brasil, não é basicamente de falta de recursos financeiros, mas antes o de aplica ção adequada ..." (VIEIRA, 1983:218). 
tentativa discursiva de separação entre administração e polí tica e da neutralidade técnica. Esta tentativa corresponde às novas condições econômicas e políticas, no Brasil e na América Latina, em decorrēncia da agudização dos conflitos sociais, expressos internamente pelos movimentos reevindicativos da década de 1950/60 e externamente, pela Revolução Cú bana, em janeiro de 1959.

Em 1956, acentuando que "... a estagnação e a misé ria constituíam potencial de subversão, bem mais perigoso do que a ameaça soviética ou chinesa, Juscelino Kubitschek lança a idéia de uma operação Pan-Americana, (OPA), programa de cooperação econōmica e financeira, visando o processo de industrialização do país. Em 1961, em decorrência daquela Revolução é convocado o Conselho Econômico e Social da Or ganização dos Estados Americanos (OEA) para traçar um progra ma de assistência ao desenvolvimento sócio-econōmico da América Latina, incorporando-se muitas idéias originais da OPA. Na Carta de Punta del Este, o programa de cooperação denominado Aliança para o Progresso (24), baseava-se numa estrutura organizacional tríplice - OEA - BID e CEPAL, cabendo a es ta a formação de técnicos necessārios ao novo programa (FGVCPDOC, 1984:64, 65).

E a ideologia desenvolvimentista que permeia todo discurso em saúde até a década de 1970 e com ela, a necessidade do planejamento em saúde, decorrente da Carta de Punta

(24) Em 1963, com as mudanças políticas, no Brasil, o governo americano passou a negociar apenas com os governos estaduais que aceitassem a imposição de suas condições, os Estados da Guanabara e Rio Gran de do Norte (FGV-CPDOC, 1984:64-65). 
del Este, recomendando-se, entre outros itens:

"- preparar planos nacionais para os próximos biê nios:

"- criar nos Ministérios de Saúde unidades de planificação e avaliação;

"- aperfeiçoar a organização e administração dos recursos de saúde nacionais e locais, integrando as funções preventivas e curativas, obter um melhor rendimento dos serviços de assistência mé dica $\ldots$

"- adotar as disposições legais e institucionais que assegurem o cumprimento dos princípios e normas da medicina individual e coletiva na execução de projetos de industrialização, urbanização, mora dia, desenvolvimento rural, ..." (Arq. Hig., 1962b:92, 94), além das recomendações quanto aos sistemas de coleta de informação e de formação de recursos humanos.

A formulação de planos nacionais já vinha sendo discutido nas reuniões técnicas do Conselho Diretivo da OPS, Comitē Regional da OMS, desde os meados da década de 50 (Bol. Of. San.Pan., 1957), inserindo-se nas novas medidas de cooperação econômica. Assim, em 1959, o conselho da OEA con siderando, entre outros fatores, "as relações reciprocas e permanentes entre saúde e desenvolvimento econômico e utilidade e conveniência da assistência técnica dos organismos in ternacionais, para formulação de programa, da inclusão de ações de Saūde pública entre as medidas de cooperação econô- 
mica e reconhecendo que necessidades em saúde pública dos países americanos só poderiam ser "progressivamente resolvidos com a ajuda de capitais de que os governos não dispõem ..." resolve recomendar aos governos que: "... ao programar e negociar o financiamento do desenvolvimento económico, in cluam programas de saúde pública que são essenciais e comple mentares aos econômicos e a assessoria técnica de ops para reformulação dos programas" (Bol. Of. San. Pan., 1959:176-177

Em cumprimento à Carta de Punta del Este, a OPS, em colaboração com Centro de Estudos de Desenvolvimento (CEN DES) da Universidade Central da Venezuela, formula uma metodologia de planejamento em saúde, (CENDES/OPS, publicada em 1965). Em 1963, realiza-se no Instituto Latino Americano de Planificación Economica y Social, no Chile, o primeiro Curso de Planejamento em Saúde, organizado pela OPS/CEPAL, para fun cionários de alto nível de administração em Saúde (Bol. Of. San. Pan., 1963a) e no mesmo ano, a OEA recomenda aos Departamentos de Medicina Preventiva e às Faculdades de Saúde Pública à incorporação do ensino de planejamento em saúde (Bol. Of. San. Pan., 1963b).

Como mostra FERREIRA (1984), entre 1960/72, essas duas áreas, Medicina Preventiva e Social e Planejamento, são prioritārias na cooperação internacional, Tabela 15 e consolidadas entre 1971/1980 cedendo lugar, na presente década,pa ra utilização e relevāncia de pessoal dos serviços de saúde, integração docente-assistencial e a educação continuada.

A idéia e a prática de planejamento passam a ser incorporadas, efetivamente, no governo estadual a partir de 
1959 (25), quando são instituidas as normas para coordenação e planejamento dos serviços e obra públicas e um grupo de planejamento é incumbido do estudo de um Plano de Ação do Go verno.

TABELA 15 - Resposta internacional no apoio do desenvolvimen to da profissão médica, no período posterior a Segunda Guerra Mundial

\begin{tabular}{|c|c|c|c|c|}
\hline Área de Ação & 1945 & $\begin{array}{r}\text { Circa } \\
1960\end{array}$ & $\begin{array}{r}\text { Circa } \\
1972\end{array}$ & $\begin{array}{r}\text { Circa } \\
1983\end{array}$ \\
\hline Formação & ++ & ++ & + & \\
\hline Qualidade & +++ & ++ & + & \\
\hline Ciências Bāsicas & +++ & ++ & & \\
\hline $\begin{array}{l}\text { Bolsas países } \\
\text { desenvolvidos }\end{array}$ & +++ & ++ & + & \\
\hline Planejamento & & ++ & +++ & + \\
\hline Quantidade & & ++ & +++ & \\
\hline $\begin{array}{l}\text { Med. Preventiva } \\
\text { e Social }\end{array}$ & & +++ & ++ & ++ \\
\hline Bolsas América Latina & & ++ & +++ & ++ \\
\hline Informação Cientif. & & ++ & ++ & + \\
\hline $\begin{array}{l}\text { Desenvolvimento } \\
\text { Educativo }\end{array}$ & & + & +++ & + \\
\hline Utilização de pessoal & & & ++ & +++ \\
\hline Relevância & & & ++ & +++ \\
\hline $\begin{array}{l}\text { Integração docente- } \\
\text { assistencial }\end{array}$ & & & +++ & +++ \\
\hline Educação continuada & & & +++ & +++ \\
\hline Bolsas intra países & & & ++ & ++ \\
\hline
\end{tabular}

(25) Em nível de Secretaria, em 1945, é criada uma comissão de Planejamento em Saúde e Higiene e Assistência Social, pela Lei no 568 de 28 de dezembro de 1945, alterando-se pela Lei no 233 de 25 de agos to de 1952 . 
A politica sanitāria do Plano, incorporando o discurso da saúde como fator de desenvolvimento, deveria inci dir sobre "... causas evitáveis de doença e morte prematuras, como fatores de significação econômica", (CARLOS, 1958/1959) tomando-se medidas que visassem ao saneamento do meio, ao combate à mortalidade infantil e à profilaxia das doenças transmissiveis e endemias de massa. Também, procurar-se-ia a dinamização das unidades sanitārias, com melhoria de rendi mento de sua atuação. Além dos dois pontos, o Plano ressaltava que "... em população de baixo nível econômico, não po de o Estado deixar de atender às necessidades de assistência médico-hospitalar das classes menos favorecidas. Cumpre não esquecer, entretanto, que nesta atividade extremamente onero sa, è imperativo empregar, criteriosamente, recursos disponí veis, no sentido de obter o máximo rendimento. Neste sentido, a experiência tem comprovado que os melhores resultados são obtidos através do estímulo e auxilio às instituições privadas, ao invés do próprio Estado assumir diretamente o encargo por meio de fórmula mais onerosa e, mesmo, muitas vezes menos eficiente ..." (CARLOS, 1958/1959:11)

Neste sentido, salienta-se a "... corajosa mudança na orientação governamental que se vinha desenvolvendo no úl timo decênio, com a construção de hospitais oficiais de clínica geral ...", uma vez que "... o desenvolvimento da iniciativa estatal direta nesse setor, condiciona conseqthentemen te retraimento da participação privada, mais apta a proporcio nar assistēncia mais eficiente e menos onerosa ..." (CARLOS, $1958 / 1959: 18,19)$ 
Consequentemente, a diretriz do plano era.".. ca nalizar os recursos previstos no sentido de auxiliar e estimular a assistência hospitalar privada ... Tais recursos se rão empregados não só em auxílio para construção de novos hospitais de iniciativa privada, mais ainda em reforma e am pliações, assim como melhorias de equipamentos, visando a elevação do padrão técnico da assistência privada." (CARLos, 1958/1959: 19)

Assim, em relação à tuberculose, como já foi visto, além de intensificar o diagnóstico precoce pela abreugrafia maciça com aquisição de doze equipes móveis e estimular a imunização, mediante vacinação de BCG, O Plano de Ação am plia o número de leitos hospitalares públicos e, em convê nios com entidades, de leitos privados.

o que é bastante interessante é que se excluem des ta fórmula menos onerosa, a assistência médica-hospitalar aos doentes mentais e leprosos, propondo-se à construção de seis hospitais e ampliação de outros existentes; a instalação de ambulatórios e dispensários, os primeiros anexos às santas Casas e os segundos às unidades sanitárias, alēm de criação de 20 ambulatórios especializados para doentes caraíacos.

Quanto à organização sanitária, apesar de constatą da sua superação e dado ao insucesso das repetidas tentati vas de reformas de base, propõe-se uma reforma gradativa com a "... criação de um Conselho de Saúde, a organização da cạ reira especializada de médico-sanitarista e a reorganização técnica-administrativa das unidades sanitárias ..." (CARLOS, $1958 / 1959: 21)$ 
Analisando o Plano de Ação, CARDoso (1972:95), assinala, "... que suas limitações, assim como, a estratégia po litica adotada, levou a coexistēncia entre 1) um sistema po litico clientelísta tradicional e de mobilização de massas e 2) uma administração tradicional com a tecnocracia ..." Nota, ainda, que a politica gradualista reforçou o Executivo, em detrimento do Legislativo e da burocracia tradicional e que o plano não implantou um sistema de planejamento.

Mas, como observa LAFER (1973:30).".. a decisão de planejar é essencialmente uma decisão política, pois é uma tentativa de alocar explicitamente recursos e, implicita mente, valores através do processo de planejamento e não através dos demais e tradicionais mecanismos do sistema polí tico. A implementação do plano é, também, essencialmente,um fenômeno político, pois é uma forma de se aferir quanto da tentativa de alocar recursos e valores se efetivou ou, em outras palavras, qual a relação num dado sistema entre política e administração ..."

\section{SONHO DOS SANITARISTAS E O RETORNO $\dot{A}$ RACIONALIDADE} $(1964-1978)$

A relação entre a política e administração tornase encoberta, no período que se segue. Embora se possa di zer que, por muitas de suas caracteristicas (o autoritarismo, a centralização do poder, o fortalecimento do Executivo e o papel da burocracia), o regime politico instaurado, em 1964 guarda semelhança com a organização política e algumas idéias 
prevalentes no Estado Novo, as forças sociais que sustentam o novo regime são de composição diferente.

Esta composição diferencial resulta da alteração do padrão de desenvolvimento econômico, adotado na década de 50 e que supera o padrão adotado em 1930. Após a década de 50, não só se diversificam os ramos de atividade econômica como se deslocam para o país unidades produtivas dos países centrais. Consequentemente, são frações de burguesia associa das ao capital internacional, as classes médias mais "moder nas" e o aparelho estatal, que darão o eixo de ordenação política e econômica.

Neste sentido, altera-se a estrutura de poder, per dendo as frações da burguesia brasileira, as classes médias "tradicionais", seus representantes politicos, assim como a crescente classe trabalhadora e o proletariado industrial, gerados no desenvolvimento pós-50.

Como se pode deduzir o regime politico, designado burocrático-autoritário, mas simplesmente, como forma de re gime, ditadura, encontra suas raízes econômicas em meados da década de 50. Neste período, realmente, o capitalismo inter nacional, sob hegemonia note-americana, aumenta o grau de in vestimentos financeiros na região, inaugurando uma nova fase: a monopolística, que parece dar características próprias ao Estado de São Paulo e inclusive à Saúde Pública paulista, on de se concentrou este desenvolvimento.

O regime político, instaurado em 1964, contudo, passará por um período de acomodação dos diferentes interesses de classes e suas frações, aglutinados ou não nos prin- 
cipais partidos politicos, entre os quais predominavam o PSP, - PTB e O PSD, como anteriormente assinalados.

E o primeiro, que tendo apoiado o golpe militar, continuou a governar o Estado de são Paulo e, è no período go vernamental entre 1964 a 1969, compreendendo as gestões de Adhemar de Barros e Laudo Natel, que se tornam mais explícitas as recomendações da Carta de punta del Este, (26) no Pla no de Desenvolvimento Integrado - PLADI (BARROS, 1964).

Assim, em 1964, com a finalidade de assessoria ao Secretário, o OPS nomeou dois "experts" para reorganização da Secretaria, o professor Herman E. Hilleboe, presidente da Associação Americana de Saúde Pública e professor de Prática de Saúde Pública da Universidade de Columbia e o professor Morris Schaefer, professor de Administração Pública, da Un $\underline{\underline{1}}$ versidade de Nova York e do Departamento de Saúde dos Esta dos Unidos. (Bol. Of. San. Pan., 1964:293-294)

Ao mesmo tempo, è proposto convênio com a "... UNICEF para favorecer a integração harmoniosa dos recursos federais, estaduais e municipais, e assim consolidar a organização proposta em bases mais definitivas e menos refratá rias à interferência política ..." (LEMOS, 1967).

(26) É possível que essa maior adesão os princípios, na ärea de saúde se ja devido à presença na cúpula administrativa de M.M. Lemos, funció nário do Ministério de Educação e Saúde, em 1961 e, posteriormenteda, OPS em diversos países. Foi chefe de gabinete da Secretaria de Saúde entre 1963 e 64; presidente de Grupo de Trabalho que elaborou - PLADI; elaborou a minuta do Convenio Internacional com a OPS/OMS para reorganização dos Serviços Sanitários. Foi Secretārio de Saüde entre 1966 e 1967 e, posteriormente, entre 1971 e 1972, nos dois governos de Laudo Natel. Foi Ministro da Saúde entre 1972 - 1974 , no governo Medici (1969 - 1974) em substituição a Rocha Lagoa. (LEMOS, 1967; FGV-CPDOC, 1984:1800). 
Bastante interessante, neste PLADI, é a fundamenta ção que leva à sua formulação as transformações de uma socie dade urbano-industrial, o aparecimento de novas forças políticas, a importação de hábitos de consumo individual e a im possibilidade de atender às aspirações deste consumo, uma vez que "... a importação de técnicas produtivas não ocorre nas mesma velocidade, resultando em tensões sociais." (BARROS, 1964:7)

Face às tensões. "... os que detêm o poder político devem ser sensiveis àquelas tensões, de forma a poder absorvê-las dentro dos quadros das instituições vigentes, a fim de permitir a realização do desenvolvimento econômico, sem criar descontinuidade no processo histórico ..." (BARROS, $1964: 7)$

o processo ocorreria numa "... sociedade aberta,em grau crescente, de igualdade de oportunidades e o respeito aos direitos individuais... pois a cada liberdade indivi dual conseguida não pode ser cedida aos demagogos totalitá rios, sob a promessa de que tal abdicação é necessária ao de senvolvimento econômico ..." (BARRos, 1964:8)

Na realização de tal sociedade, teria a descentralização do poder político e econômico, papel fundamental,"... - Governo, de um lado, fortalecerá as unidades locais de ad ministração e estimulará o seu aperfeiçoamento, aumentando a eficácia, de outro, criará as condições para que o setor privado possa desempenhar, a contento, sua missão, criando facilidades para os investimentos, orientando-o sobre o sen tido geral do desenvolvimento e intervindo supletivamente quan do as condições o recomendarem ... E a fé inabalável nas 
virtudes da sociedade democrática ... que nos leva a apre sentar o PLADI ... e a proposta da criação de uma Secretaria de Economia e Planejamento que preserve a unidade da política econômica do Estado e, ao mesmo tempo a adapte às mutá veis condições de conjuntura ..." (BARROS, 1964:8), virtudes que serão violadas.

Favorecida pelas condições do comércio internacional e após um período de recessão, a economia brasileira inau gurou um novo ciclo econômico, de internacionalização de cá pital, com a exportação de produtos semi-industrializados e industrializados.

A expansão econômica, a partir de 1968, vinculou-se a elevação de entrada de capitais internacionais e às politi cas fiscais, monetárias e salariais. De um lado, a restrí ção de crédito e a diversificação industrial com um nível tecnológico mais complexo e investimentos mais amplos asfixiaram as pequenas e médias empresas, voltadas para os merca dos locais e regionais, favorecendo as grandes empresas e os conglomerados multinacionais. Por outro lado, a eleva ção das tarifas dos serviços públicos transferiu às classes trabalhadoras mais encargos sociais; estas alijadas de mecanismos de reivindicação pela lei anti-greve, pelo fechamento dos sindicatos, sofreram paulatinamente, perdas sucessivas na correção salarial. Enquanto, as classes médias, favorecidas pelos mecanismos financeiros e creditícios, tiveram acesso a um leque de bens de consumo duráveis, inexistentes até então Contando com a capacidade ociosa dos últimos anos anteriores e com as modificações na política econômica, após 
um periodo recessivo, entre 1962/67, em que o PIB cresceu em apenas $3,2 \%$, a economia brasileira entrou num período favorav́el, apresentando um PIB de 10,0\%, entre 1967/70, e de 12,4\%, entre 1970/73, e principalmente, com o crescimento da produção industrial $(11,98$ no primeiro período e $13,5 \%$ no se gundo) e da construção civil $(9,0 \%$ e $12,0 \%$, respectivamente) (SERRA, 1982a, b).

Essa expansão baseou-se, conforme SINGER (1976:78), em "... 1) uma demanda interna por bens de consumo duráveis em expansão, graças à concentração de renda e de mecanismos financeiros e creditícios que canalizaram parte substancial da poupança local para financiar essa demanda e ampliar o crédito ao consumidor; 2) uma demanda externa em expansão graças à liberação do comércio internacional aos produtos in dustrializados e ao subsidiamento de exportações e 3) uma forte injeção de recursos exteriores que completaram a poupan ça interna e permitiram eliminar focos inflacionários graças à capacidade de importar ..."

Concomitante, entre 1964 a 1965, colocam-se com maior agudização os conflitos internos entre as diferentes frações da burguesia e entre esta e a classe trabalhadora,co mo demonstram os fatos ocorridos nesse periodo.

Em 1966 forma-se a Frente Ampla, cujos objetivos eram a retomada do desenvolvimento econōmico, a preservação de soberania nacional e a restauração do poder civil.

Em 1967, é promulgada a nova Constituição, e são restabelecidas, embora restritas às instituições representativas (Aliança Removadora Nacional - ARENA e Movimento Demo- 
crático Brasileiro - MDB), as liberdades públicas. Entre 1967 e 1968, eclode uma série de manifestações estudantis em for ma de greves, passeatas, campanhas do voto nulo, choques com militares; e outra série de movimentos operários com greves, as primeiras desde 1964, em Minas Gerais (Contagem) São Pau 10 (Osasco), em 1968 e Rio de Janeiro. No final de novembro de 1968, assite-se ao divórcio entre o Legislativo e o Execu tivo e decreta-se o Ato Institucional no 5, suspendendo os direitos democráticos (WEFFORT, 1972; EVERS, 1971; CARDOSO, $1972)$.

A centralização do poder e fortalecimento do Execu tivo foi acompanhada de uma reforma administrativa e financei ra; o governo não só criou novos órgãos necessários à rees truturação da economia, como dinamizou os existentes, iniciando a reformulação da estrutura administrativa pública federal, estabelecendo diretrizes para a modernização esta dual e municipal, necessárias à nova centralização de poder. Possibilitou, ainda, a centralização dos recursos financeiros como a reforma do sistema tributário.

A Lei no 200 de 25 de fevereiro de 1967 reorganiza rá a administração pública federal, definindo as áreas de competência dos órgãos públicos. Sob o impacto desta Lei Fe deral e da Lei no 48.040 de 01 de junho de 1967, em que se aprovou o plano de trabalho da Reforma Administrativa do Ser viço Público Federal, a Secretaria de Estado Saúde (SES) rees truturou-se. A Lei no 48.040 estabeleceu, também, a coorde nação geral da reforma à Secretaria de Economia e Planejamen to, criada em 1964, e, definiu o prazo de 30 dias para apre 
sentação de planos de trabalho para melhoria de eficiência administrativa e projetos referentes às unidades de prestação de serviços e remoção de pontos de estrangulamentos.Criou, também, o Grupo de Estudos da Reforma Administrativa, posteriormente, Grupo Executivo (GERA). As propostas de reforma passaram a ser geradas e discutidas em Grupos de Trabalho, constituídos pelo Executivo.

Em maio de 1967, o plano que fixou as diretrizes básicas para a reformulação da Secretaria, delineou quatro áreas de ação conjugada:

"1. ārea deliberativa, cabendo as decisões estraté gicas, no sentido de imprimir uma política de saúde à organização ...

2. área executiva - agrupando os inúmeros órgãos da Secretaria em quatro Coordenadorias (Saúde da Comunidade, Saūde Mental, Assistência Hospi talar e de Serviços Técnicos Especializados)...

3. área assistencial - assessora - compreendendo atividades de informação, anālise e normas téc nicas e planejamento ...

4. área assistencial - auxiliar - reunindo atividades de administração geral" (SES, 1971:8).

Chama a atenção na reestruturação da Secretaria, a abordagem diferencial para duas áreas de atuação tradicional: a doença mental e a lepra. Na primeira, assinalando o reconhecimento internacional para a reformulação da assistēncia ao doente mental e as deficiências acumuladas desta assistên cia no Estado, posterga-se sua integração justificando-se pe 
lo fato de que "... a grande maioria dos internados apresenta problemas sociais que não permitem seu retorno ao seio da familia e o Estado não conta com entidades sociais que possam assumir tão volumoso encargo. Assim, os grandes hos pitais psiquiátricos serão, ainda por muito tempo, um mal necessário ... Procurou-se fazer com que os novos doentes internados recebessem a necessāria atenção médica ... evitan do-se a internação crônica ..." (SES, 1971:15) . Concomitantemente, incrementou-se o nümero de leitos mantidos, mediante convênios com entidades privadas.

Quanto a lepra, "... a reforma administrativa, sụ bordinando os antigos sanatōrios à Coordenadoria de Assistên cia Hospitalar e englobando os ex-dispensários aos centros de saúde, atendeu às recomendações internacionais relativas à integração da prevenção da hanseníase nos programas de saúde pública. Por outro lado, extinguindo-se o antigo Departamen to de Profilaxia da Lepra,.".. eliminou o órgão dentro e em torno da qual se desencadeavam as nefastas tormentas politicas e emocionais ..."(SES, 1971:18), eliminando-se, também as pensões aos egressos dos sanatórios "... já que o latual critério de internação não favorece a formação de egressos ..." Os antigos doentes "... que tinham oferecido o seu trabalho ao Estado e que se invalidaram e envelheceram na chamada "laborterapia" foram recompensados e, praticamente, equiparados aos servidores públicos, alguns até mesmo integrados no quadro do funcionalismo ..." (27) (SES, 1971:19)

(27) Esse fato chama a atenção para uma das características, dos serviços püblicos, o "recolhimento" de pessoas que, quer seja por fatores limitantes ou por fatores etários não encontram emprego nas empresas privadas. 
Contudo, "as nefastas tormentas politicas e emocio nais", também, estavam presentes na área de saúde mental.Em 1967, o deputado Murillo Souza Reis solicita uma Comissão Par lamentar de Inquérito, informando "... a existēncia de"gang" na concorrência fraudulenta, compra de medicamentos através de comissões ... para os hospitais de assistência aos psicopatas ..." (D.O. 2, 3, 4.03.1967). Na denúncia, constata a existência de dois grupos:

" ... Há trinta anos instalados, duas · entidades dentro da Secretaria, uma tomou nome de "turma de troica" e outra "azul celeste"...a primeira constí tuída pelos que trabalham. E gente boa, digna, de cente ... dignificam o Estado e a administração. Azul celeste é muito conhecida. E formada por aqueles apaniguados politicos que não reunem condi ções morais para administrar a coisa pública, en tram no funcionalismo com referências baixas, en tram em poucos meses galgam com firmeza altos pos tos na administração ... Sobrevivem em todos go vernos ..." (D.0.08.03.1967)

A saúde mental continuou a ocupar uma grande e im portante área na estrutura sanitāria, enquanto que as áreas de lepra, de tuberculose e da assistência materno - infantil perdem o espaço que ocuparam, por um longo período. Analisan do as diferentes propostas de reorganização, há indicios de que essa reestruturação dependia de negociações entre dife rentes grupos burocrāticos, impondo-se àqueles com maior for ça política externa, dos quais, provavelmente, os ligados a 
área de saúde mental.

A proposta de 1957 criava uma estrutura composta de cinco Departamentos de Unidades Sanitárias, de Saneamento, de Normas Médica-Sanitaristas, de Assistência Hospitalar e - Instituto Butantã, alēm do Departamento de Administração jā existente. Nesta reestruturação, foram separadas as ativida des ambulatoriais, subordinadas ao Departamento de Unidades Sanitārias das atividades hospitalares, subordinadas ao Departamento de Assistência Hospitalar com seis divisões (Admi nistração Hospitalar, Hospitais Gerais e Especiais,Hospitais de Tuberculose, de Sanatórios de Lepra, Moléstias Mentais, de Administração) e o Instituto de Cardiologia. (SSPAS, 1957)

Entre 1964 a 1966, a proposta de reformulação cria va apenas três superintendências: Saúde da Comunidade, Hospitais e Pesquisa. (LEMOS, 1967)

A reestruturação do Decreto Lei no 50.192 de 13 de agosto de 1968 instituiu quatro Coordenadorias: Saúde da Comunidade, Assistēncia Hospitalar, Saúde Mental, Serviços Técnicos-Especializados. (SES, 1972) Nesta reforma administrativa, a Secretaria contou com a participação de empresas particulares, especializadas em planejamento que se encarregaram de diferentes projetos, referentes ao descongestionamen to da cúpula da pasta (Projeto Gera 37/67), à estruturação de um sistema técnico-normativo da Secretaria de saúde (Projeto Gera 38/67) e à organização de uma unidade regional de atuação integrada da Secretaria (Projeto Gera 39/67).

O Decreto no 50.192 dispunha sobre as medidas da Reforma Sanitária. As diretrizes referiam-se à estruturação 
adequada das unidades de prestação de serviços, à regionalização de atividades, à adequada supervisão das unidades re gionais e locais, à distribuição adequada de trabalho e de competências e utilização plena de recursos.

A regionalização das atividades obedeceu a crité rios e decretos emanados e reestruturados da secretaria de Economia e Planejamento, a quem coube o poder de determinar a criação de novas unidades inferiores à sub-região ou áreas especiais. De acordo com a regionalização, foram criadas dez Divisões Regionais de Saúde e, posteriormente onze, com 0 desmembramento das sub-regiões de Marilia, Assis e Tupã, da Região de Bauru e a extinção da região são Paulo exterior, cujas sub-regiões foram incorporadas às regiões de Campinas e de Santos.

E provável que a nova reorganização administrativa tenha destruido as bases politicas partidārias dos antigos partidos dominantes. A série de reformas empreendida atin gia "os currais eleitorais" do PSD, do PSP e PTB (28).

"... a administração pública visava racionalizar a organização e os métodos da máquina burocrática de modo a capacitá-la para o desempenho eficiente das funções que the correspondem no quadro do capitalis mo maduro, dominado pelas grandes empresas. No pla no político-partidário, tal reforma tenderia a destruir as fontes de alimentação de práticas clien

(28) Outra importante reforma, alem da territorial e administrativa, in cidia sobre as relaçóes do Sindicato com a Previdencia Social e Mi nistërio do Trabalho. 
telisticas que bloqueavam a alternativa do poder. Tratava-se de fechar as portas do tesouro e dos empregos püblicos que o Estado Cartorial franquea va aos dirigentes do PSD e PSP ..." (CARDOSO, 1972)

O mesmo Decreto no 50.192 estabeleceu as ativida des de saúde pública, excetuando a assistência hospitalar, englobadas em programas desenvolvidos (D), desenvolvido com algumas exceções (DCE), resumido (R) e minimo (M), conforme Tabela 16, a serem desenvolvidos nas unidades regionais (Di visão de Saúde), sub-regionais (Distrito Sanitários) e lo cais (unidades sanitārias). Como pode ser observado, grande parte das atividades já era tradicionalmente desenvolvida pe la Secretaria, tendo-se incorporado apenas técnicas de programação.

Para descentralização executiva, foram criados ór gãos de administração e planejamento nas Divisões Regionais de Saúde e para a integração em nível local, foram incorpora dos aos Distritos Sanitários, unidade básica da organização, os diferentes tipos de órgãos de prestação de serviços (pos tos, centros, postos de puericultura, dispensários de le pra, de tuberculose ou tracoma e higiene visual), passando a ser classificados, de acordo com o número de população abrangida, em postos de atendimento, postos de saúde e cen tro de saúde.

A reestruturação reduziu para 12 Diretorias de $\mathrm{D} \underline{\underline{i}}$ visões Regionais, as 20 Delegacias do Departamento de Saúde e 15 Delegacias do Departamento de Lepra, passando os delega dos a exercer funções de inspeção e assessoria às respectivas divisōes. 
TABELA 16 - Programas e atividades de saúde pública desenvol vidos nas unidades de prestação de serviços, Se cretaria de Saúde, São Paulo, 1968

\begin{tabular}{lcccc}
\hline \multicolumn{1}{c}{$\begin{array}{c}\text { Programas } \\
\text { Atividades }\end{array}$} & D & DCE & R & M \\
\hline Controle de Doenças Transmissiveis & $\mathrm{x}$ & $\mathrm{x}$ & $\mathrm{x}$ & - \\
Controle de Tuberculose e Hanseniase & $\mathrm{x}$ & $(1)$ & $(1)$ & - \\
Saneamento & $\mathrm{x}$ & $\mathrm{x}$ & $\mathrm{x}$ & $\mathrm{x}$ \\
Higiene materna e da criança & $\mathrm{x}$ & $\mathrm{x}$ & $\mathrm{x}$ & - \\
Odontologia sanitária & $\mathrm{x}$ & $\mathrm{x}$ & $\mathrm{x}$ & - \\
Nutrição & $\mathrm{x}$ & $\mathrm{x}$ & - & - \\
Assistēncia médico-sanitāria & $(2)$ & $(3)$ & $(1)$ & $(4)$ \\
Enfermagem & $\mathrm{x}$ & $\mathrm{x}$ & $\mathrm{x}$ & - \\
Educação Sanitāria & $\mathrm{x}$ & $\mathrm{x}$ & $\mathrm{x}$ & $\mathrm{x}$ \\
Visitação Sanitária & - & - & - & $\mathrm{x}$ \\
Imunização & - & - & - & $\mathrm{x}$ \\
Epidemiologia e Estatística & $\mathrm{x}$ & $\mathrm{x}$ & $\mathrm{x}$ & - \\
Laboratōrio & $\mathrm{x}$ & $\mathrm{x}$ & - & - \\
Administração & $\mathrm{x}$ & $\mathrm{x}$ & $\mathrm{x}$ & -
\end{tabular}

(1) não especializada riamente especializada

(2) especializada

(4) intermitente
(3) não obrigato FONTE: Dados elaborados a partir de SES, 1972:23. 1630 Unidades, em 1967, incluindo-se delegacias, institutos, hospitais, seções, serviços e divisão administrativa. A Tabela 17 mostra as Unidades existentes, segundo Delegacia de Saúde de são Paulo e Interior. Excluindo-se as acima referí das, observa-se que a Secretaria contava com 1493 unidades, $77,8 \%$ delas instaladas no Interior e o restante, na Delegacia de Saúde de são Paulo. 
TABELA 17 - Tipos de unidades sanitárias, segundo Delegacia Regional de São Paulo e Interior, 1967

\begin{tabular}{|c|c|c|c|}
\hline Delegacia & São Paulo* & Interior & Total \\
\hline 1. Centro de Saúde & $66(55)$ & 105 & 171 \\
\hline Votantes & $2(2)$ & - & 2 \\
\hline 2. P.A.M.S. & 36 & 480 & 516 \\
\hline 3. Dispensários & & & \\
\hline 1. Tuberculose & 51 & 18 & 69 \\
\hline Volantes & 8 & 3 & 11 \\
\hline 2. Tracoma e Higiene Visual & 9 & 30 & 39 \\
\hline Postos & - & 36 & 36 \\
\hline 4. Lepra & 15 & 41 & 56 \\
\hline 5. Psicopatas & 2 & - & 2 \\
\hline 4. Postos de Puericultura & $129(128)$ & 427 & 556 \\
\hline Unidade Volante & 9 & 19 & 28 \\
\hline 5. Serviço Obstétrico Domiciliar & 4 & 3 & 7 \\
\hline Sub total fixo & 308 & 1137 & 1445 \\
\hline Volante & 23 & 25 & 48 \\
\hline Total Geral & 331 & 1162 & 1493 \\
\hline
\end{tabular}

* Os dados ( ) referem somente ao Município de são Paulo. FONTE: Dados brutos LEMOS (1967).

Além dessas unidades, a Secretaria contava com 31 hospitais, distribuídos conforme Tabela 18. 
TABELA 18 - Número de Hospitais, segundo divisões administra tivas, Secretaria de Saúde, Estado de São Paulo, 1967

\begin{tabular}{lccc}
\hline Local & São Paulo & Interior & Total \\
Tipo & 1 & 8 & 9 \\
\hline $\begin{array}{l}\text { Divisão de Tuberculose } \\
\begin{array}{l}\text { Departamento de Profilaxia } \\
\text { de Lepra (Sanatórios) }\end{array}\end{array}$ & 2 & 3 & 5 \\
$\begin{array}{l}\text { Departamento de Assistencia } \\
\text { a Psicopatas }\end{array}$ & 4 & 2 & 6 \\
$\begin{array}{l}\text { Serviço de Medicina Social } \\
\text { Departamento Estadual da } \\
\text { Criança }\end{array}$ & 1 & 8 & 9 \\
Instituto Butantan & 1 & - & 1 \\
\hline T T A L & 1 & - & 1 \\
\hline
\end{tabular}

FONTE: Dados brutos, LEMOS (1967).

Em 1970, pela Resolução SS no 1 de 17 de março de 1970, os Centros de Saúde foram classificados em quatro tipos e em 1973, em cinco, Tabela 19.

Nas duas datas, observa-se um maior número de Cen tros de Saúde do tipo IV e V. Em 1970, os Centros de Saúde IV correspondiam a 46,38 do total de Centros de Saúde. Em 1973, 75,88 dos Centros de Saúde existentes eram do tipo IV e V. Se se considera o Decreto no 50.192 de 13 de agosto de 1968, que estabeleceu os programas e atividades desenvolvidas nss unidades de prestação de serviços (v. Tabela 16) mais da metade dos Centros de Saúde deveriam ser restringir ao sanea mento do meio, à assistência médica intermitente ou quase nula, à imunização e eventual quimioprofilaxia, educação 
TABELA 19 - Centro de Saúde, segundo tipo e divisão regional de saúde, Secretaria de Saúde, São Paulo, 1970 e 1973

\begin{tabular}{|c|c|c|c|c|c|c|c|c|c|c|c|}
\hline \multirow{2}{*}{$\begin{array}{l}\text { Ano } \\
\text { Tipo } \\
\text { Div.Regional }\end{array}$} & \multicolumn{5}{|c|}{1970} & \multicolumn{6}{|c|}{1973} \\
\hline & I & II & III & IV & Tota 1 & I & II & III & IV & $\mathrm{v}$ & Total \\
\hline DRS1 & 21 & 11 & 26 & 25 & 83 & 21 & 11 & 16 & 25 & 121 & 194 \\
\hline DRS 2 & 3 & 3 & 1 & 9 & 16 & 3 & 2 & 1 & 4 & 4 & 14 \\
\hline DRS 3 & 3 & 4 & 4 & 4 & 15 & 3 & 4 & 4 & 6 & 15 & 32 \\
\hline DRS4 & 4 & 4 & 9 & 12 & 29 & 5 & 3 & 8 & 12 & 33 & 61 \\
\hline DRS5 & 7 & 6 & 10 & 20 & 43 & 8 & 6 & 10 & 20 & 38 & 82 \\
\hline DRS6 & 4 & 3 & 9 & 20 & 36 & $\cdot 4$ & 3 & 9 & 20 & 43 & 79 \\
\hline DRS7 & 7 & 2 & 10 & 21 & 40 & 3 & - & 5 & 8 & 22 & 38 \\
\hline DRS 8 & 5 & 5 & - & 25 & 35 & 5 & - & 5 & 25 & 45 & 80 \\
\hline DRS 9 & 2 & 1 & 4 & 11 & 18 & 2 & 1 & 4 & 11 & 19 & 37 \\
\hline DRS10 & 2 & 2 & 12 & 12 & 28 & 2 & 2 & 12 & 12 & 23 & 51 \\
\hline DRS11 & - & - & - & - & - & 4 & 2 & 5 & 13 & 22 & 46 \\
\hline DEVALE & - & - & - & - & - & 2 & 1 & 1 & 5 & 9 & 18 \\
\hline $\mathrm{T} O \mathrm{~T} A \mathrm{~L}$ & 58 & 41 & 85 & 159 & 343 & 62 & 35 & 80 & 161 & 394 & 732 \\
\hline$\%$ & 16.9 & 12.0 & 24.8 & 46.31 & 100.0 & 8.5 & 4.8 & 10.9 & 22.0 & 53.8 & 100.0 \\
\hline
\end{tabular}

FONTE: Dados brutos (SES, 1972:279-282); GONÇALVES et alii, 1974:72.

sanitária e visitação sanitária. Considerando-se que, estes tipos de unidades, funcionam em precário prédio alugado e, pelo menos, com dois funcionários, em geral, servente e/ou atendente com pouca formação e treinamento, é de se supor que atividades previstas não foram desenvolvidas.

A reforma criou inúmeros cargos administrativos de coordenação, considerando-se os 730 Centros de Saúde, 74 Dis tritos Sanitários e 12 Divisões Regionais de Saúde, além de órgãos de Administração (GONÇALVES et alii, 1974) ou seja, 
criou uma organização altamente burocratizada e centralizada Contudo, a reestruturação enfrenta limites imedia tos na sua implantação. Se, na antiga organização, como bem assinala MASCARENHAS (1949), reafirmado por LEMOS (1967) pre valeciam as forças político-partidārias na nomeação das che fias, na nova organização, enfatizava-se o critério racional, neutro, do técnico especializado nos novos métodos de adminis tração (planejamento, organização de serviços, epidemiologia, estatistica). O conhecimento técnico-cientifico tornou-se um critério legal para os cargos administrativos e de ascensão hierárquica. E ao ter como pressuposto de que a modernização da estrutura dependia de uma mentalidade que se difundia na organização, a Reforma privilegiou a formação de recursos humanos e especificamente, enfatizou a do médico sanitarista, elemento propulsor das mudanças.

A absorção deste profissional, contudo, deve ser vista dentro de um quadro geral de fortalecimento do Executi vo, de reorganização do aparelho estatal e de aliança de no vas forças políticas pós-64 e que tem como base de apoio as classes médias na implantação de novas bases de legitimação.

A possibilidade de absorção do médico sanitarista contudo, só se concretizará mais intensamente em meados da década de 70, em consequência da expansão das escolas médicas, a partir de 1968 e da formação especializada, criando una maior disponibilidade de mão-de-obra. A Tabela 20 mos tra a produção de médicos para o Brasil, entre 1941 a 1976. 
TABELA 20 - Produção anual de médicos, Brasil - 1941/1976

\begin{tabular}{lc}
\hline ANO & No graduados \\
\hline 1941 & 878 \\
1950 & 1.070 \\
1960 & 1.528 \\
1967 & 2.039 \\
1968 & 2.713 \\
1969 & 3.212 \\
1970 & 3.306 \\
1971 & 3.721 \\
1972 & 5.301 \\
1973 & 6.613 \\
1974 & 7.722 \\
1975 & 8.284 \\
1976 & 8.641 \\
\hline
\end{tabular}

FONTE: SACRAMENTO, apud CORDEIRO (1984:113)

E de se supor que, aproximadamente, $35 \%$ dessa pro dução ocorresse, no Estado de São Paulo, uma vez que, em 1986, essa era a porcentagem de vagas oferecidas, num total de 7.767 vagas (Bol. Ass. bras. Ed. Med., 1986).

Entre 1976 a 1978, a Secretaria estabelece convê nio com a Faculdade de Saúde Pública e o Ministério da Saúde para formação de sanitaristas, em cursos semestrais.

Considerando-se, no entanto, a atração exercida por outras especialidades médicas, mesmo esses cursos semes trais conveniados foram insuficientes para o nümero de car gos previstos. A Figura 1 mostra o quadro existente, em 
FIGURA 1 - Número de cargos vagos, providos e ocupados da carreira de médico sanitarista, 1974 e 1978
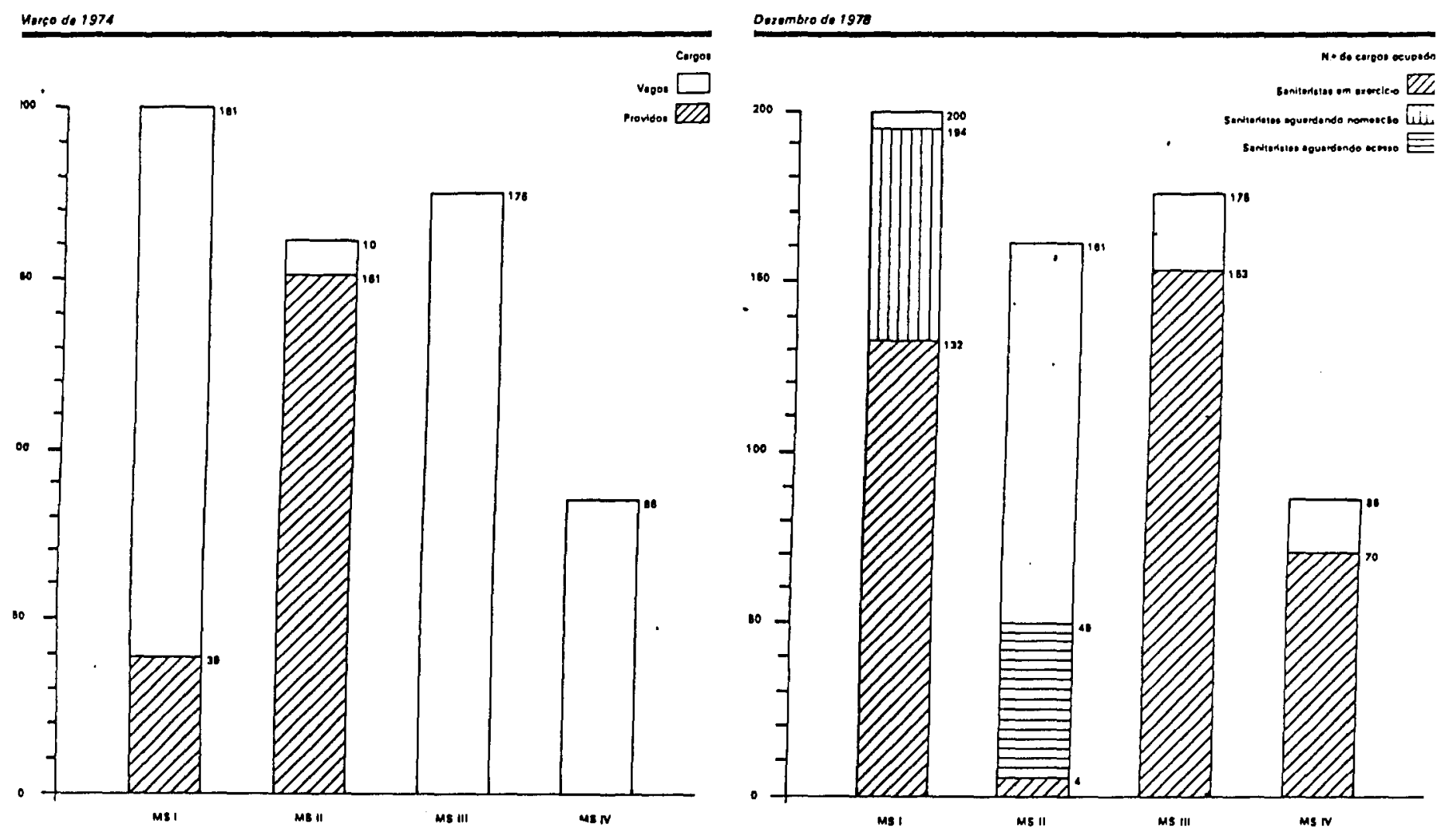

FONTE: SES (1979).

1974 e 1978, demonstrando que, neste último ano, parte dos cargos continuava vaga. Em 1975, dos 622 cargos criados, 432 (698) ainda se encontravam vagos. (SES, 1979:17)

Esse vacāncia, segundo a Secretaria, devia-se a "... inadequação da política de recrutamento para os cursos de saúde püblica, a qual vinha sendo desenvolvida no sentido de serem encaminhados para esses cursos, médicos efetivos do seu quadro, que tivessem um mínimo de dois anos de exercício como médicos consultantes... A maioria desses médicos con sultantes, com atividade profissional consolidada, trabalhan do em tempo parcial e, portanto, com clientela particular já 
formada e mentalidade dirigida para a medicina assistencial e individualizada, muitas vezes não estava disposta a assu mir os pesados encargos exigidos pelo exercício do cargo de médico sanitarista, incluindo o compromisso de trabalhar em regime de dedicação exclusiva" (SES, 1979:17).

Como ressalta o relatório, "... por outro lado de lineara-se novo e fértil campo de recrutamento, constituído por jovens médicos recém-formados nos bancos escolares, espe cialmente nos departamentos de Medicina Preventiva e Pedia tria, que vinham recebendo formação e estímulo para o campo da saúde pública ..." (SES, 1979:17). Isto, provavelmente, de corre da implantação junto àqueles departamentos, via recur sos financeiros internacionais de programas de extensão de cobertura, cuja proposta, com as estratégias de atenção pri mária e participação comunitária fora apresentada na terce ra Reunião Especial de Ministros da Saúde das Américas, em 1972 . (29)

A captação de recursos, contudo, exigia a estreita colaboração entre os órgãos de saúde pública e os de ensino médico, possibilitando "... maiores oportunidades de forma ção profissional e situar o estudante no contexto da realida de sanitária e sócio-econômica, onde vai exercer a sua atividade profissional e dentro dos amplos objetivos da medicina social ..." (NATEL, 1972:204).

(29) Esta proposta torna-se referencia para IV Reunião, cujo informe cons tituiria a contribuição que as regiōes da América deveriam fazer à Conferência Internacional de Atenção Primária a Saúde, de Alma Ata, em 1978 e é incorporada, quase dez anos após, em 1980, no Prev-Saüde. 
Em 1973, ressaltava-se que a "... Secretaria de Saúde, colaborando com o ensino médico celebrou convênios com a Faculdade de Ciēncias Médicas da Santa Casa, Escola Paulista de Medicina, Faculdade de Medicina da Universidade de São Paulo, Fundação Regional de Ensino Superior Araraqua rense, Fundação Luzíadas, Faculdade de Ciências Médicas e Biológicas de Botucatu, Fundação Municipal de Ensino Supe rior de Marilia, Fundação Universitária do $\mathrm{ABC}$, Faculdade de Saúde Pública da USP, objetivando o funcionamento dos Centros de Saúde Escola, na Barra Funda, Vila Mariana e nos Cen tros de Saúde de Paulínia, São José do Rio Preto, Peruíbe, Bo tucatu, Marília e Santo André ... Estas unidades servem à instrução de alunos de medicina no campo da medicina preventiva e ao treinamento de pessoal auxiliar da secretaria ..." (NATEL, 1973:203). Embora alguns convēnios datassem de anos anteriores.

A captação de recursos humanos, também, deve ser vista como resultante das condicões politicas do país, que canalizarão para aqueles departamentos graduandos com participação ativa nas organizações estudantis e desejosos de dar um sentido político ao saber profissional, expresso na vontade de "trabalhar com a população, com a comunidade", e, posteriormente, no planejamento e gerenciamento de serviços de saúde pūblica, dentro de uma perspectiva de transformaçãa Essa opção verifica-se, também antes de 1964, entre os pro fissionais que frequentavam o curso de Saúde pública e, de pois de meados da década de 1970, com o declínio dos movimen tos de guerilha. (30)

(30) Comunicaçōes pessoais. 
Considerando-se, contudo, o pequeno número de va gas para Residência naqueles Departamentos e que, ainda, os residentes deveriam especializar-se em Saūde Pública para sua posterior inclusão no quadro da secretaria, a absorção era bastante limitada.

Esse panorama modificou-se, após 1976, com uma maior disponibilidade de mão-de-obra médica; com o convênio entre a Faculdade de Saúde Pública, Ministério de Saúde e Se cretaria para realização de cursos semestrais com 50 alunos; com $\circ$ aumento de vagas para as Residências de Medicina Pre ventiva ou Medicina Social ou Saúde Pública e, finalmente, a instalação e expansão de cursos particulares de Saúde Públi ca, alēm da equivalēncia de títulos entre os formandos na Fâ culdade de saúde pública e nas Faculdades de Medicina, nas āreas acima referidas, entre 1979/90.

Em 1980, Leser, Secretārio de Saúde nas gestões de 1964/1969 e 1974/1979, declarava que seu cálculo era de 2.200 sanitaristas "... partindo do seguinte ponto: o Estado, vai precisar, na melhor das hipóteses, na mais modesta ava liação, de uns 1.200 Centros de Saúde, chefiados por sanitaristas. Não estou dizendo unidades. Vocē pode ter unidades menores com sanitaristas comandando à distāncia, tipo PASPosto de Atendimento Sanitário ..." (Bol. inf. Ass. med. Sanit, $1980: 31$

E, realmente, são os PAS, previstos pela Reforma, que foram restabelecidos, em 1976, pelo Decreto no 8.648, "... atuando como extensão do Centro de Saúde, o PAS permiti rá atender grupos populacionais em áreas cuja localização di 
ficulta o acesso ao Centro. A medida conta com a participa ção do Poder Püblico Municipal que provê o prédio e os servi dores responsabilizando-se a Secretaria pelo abastecimento e atendimento médico periódico. Já foi firmado o primeiro con vênio com a Prefeitura de Presidente Prudente, para assistên cia a três Distritos do Município, havendo outros em tramita ção ..." (SAUDE, 1977a:1; MARTINS, 1977:1). Em 1977, realizam-se estudos "... para assinatura de acordo com o Departamento de Comunidade (antigo Departamento de Assistência à In fância e à Maternidade - DAIM), da Secretaria de Higiene Mu nicipal (São Paulo) para integração da rede de Centros de Saúde no Município, uniformizando programas e assegurando es treita cooperação ..." (MARTINS, 1977:9)

Esse acordo, provavelmente, soluciona a problemátí ca de expansão de rede da Secretaria na região da Grande são Paulo, uma vez que "... a construção de centros de saúde ain da não atingira as metas fixadas para a Grande são Paulo, em virtude de problemas operacionais e financeiros, ligados à implantação da rede física" (MARTINS, 1977:244), não havendo referência ao interior do Estado.

Em 1978, é vetado o projeto de Lei no 83, que visa va "... a autorizar o Governo do Estado a firmar convênio com as Prefeituras no sentido de serem utilizados os Centros de Saüde estaduais nos períodos ociosos. A medida é justifí cada com a alegação de que tais unidades da secretaria de Saúde não funcionavam aos sábados e domingos e de que essa capacidade ociosa poderá ser usada pelas prefeituras, median te recursos próprios, para atendimento de emergência" (MARTTNS, 
1979:1002-1003). Apesar de recorrer a Lei Federal no 6.229 de 17 de julho de 1975, que dispunha sobre a organização do Sistema Nacional de Saúde e necessidade de articulação das três esferas administrativas e a proposta da criação do Fun do Estadual de Saúde (FUNDES) "... visando implantar aquele sistema no âmbito do Estado ...", o Executivo veta a proposi tura considerando-a inoportuna, devendo ser apreciada "... no conjunto de medidas que comporão o sistema estadual de saúde" (D.O. 20.10.1978), demonstrando que o governo estạ dual não se propunha a assumir a assistência integral, via Secretaria.

Duas razões justificam tal veto: que os Centros de Saúde não dispunham de equipamento próprio para assistência dessa natureza (atendimento de emergência e pronto socorro médico-hospitalar). E uma segunda razão era o convēnio fir mado entre Secretaria e o Instituto Nacional de Assistência Médica e Previdência Social (INAMPS), em 1976 e ratificado em 1977, "... objetivando o melhor aproveitamento de seus recursos humanos e materiais existentes e concedendo ao INAMPS, a utilização das instalações, serviços e pessoal dos Centros de Saúde da Secretaria ..." (MARTINS, 1979:1003)

Como bem assinalado, esse convênio possibilitou, ao INAMPS, uma economia de recursos (instalação, serviços e pes soal dos Centros de Saúde), além de ampliar sua rede de aten dimento e diminuir a pressão da demanda dos seus postos de assistência. Por outro lado, possibilitou à Secretaria o acesso a recursos financeiros federais. Fenōmeno esse (historicamente comum) e que ocorre, também, na década de 1970, 
com a implantação, pelo Decreto n! 52.790, de 20 de agosto de 1971, do Centro de Integração das Atividades Médicas (CIAM), resultante de convênio entre o Ministērio do Trabalho e Previdência Social, via Instituto Nacional de Previdência So cial (INPS) e a Secretaria de saúde, com objetivo de inte grar os serviços médicos de ambos órgãos e prevendo o desenvolvimento dos seguintes programas bāsicos:

"1. assistência médica aos beneficiārios do INPS, mediante utilização de instalações, serviços e pessoal dos Centros de Saúde da Secretaria, fo ra do horário normal do expediente.

"2. admissão de pessoal técnico e auxiliar para sụ prir deficiēncias do quadro de servidores das unidades assistenciais do INPS.

"3. serviços complementares de diagnósticos e tera pia, pelos próprios Centros de saúde ou por outros órgãos da Secretaria ...

"4. implantação, em carāter experimental, de comunidades de saúde com a incorporação de recursos médico-sanitārios, pertencentes aos Poderes Federal, Estadual e Municipal, as. Fundações, às Autarquias e às entidades particulares que operam no setor saúde, obedecida a Política Na cional de Saúde, formulada pelo Ministério da Saúde.

5. "constituição de órgão coordenador das atividạ des referidas no convênio, com a finalidade de administrā-lo e desenvolver outras ações necessárias para a progressiva integração de ativida 
des médicas assistenciais do Estado de São Pau 10..." (CIAM, 1972:34)

Em 1972, o CIAM "... valendo-se dos estudos e le vantamentos, realizados pela Coordenadoria da Saúde da Comunidade, dos recursos disponíveis nos Centros de Saúde da Ca pital e do Interior do Estado de São Paulo, e dentro de uma programação estabelecida, a vista da indicação, pelo INPS, de suas necessidades, selecionou e instalou 71 Centros de Saúde ..." (CIAM, 1972:5). Em 1974, constata-se um total de 240, distribuídos conforme Tabela 21 .

TABELA 21 - Número de Centros de Saúde, convēnio MTPS e Secre taria, por regiões administrativas do Estado, 1971 e 1974

\section{Ano}

Região

1971

1974

Grande São Paulo 30

Litoral

Vale do Paraíba

1

1

Sorocaba

$-6$

Campinas

- 11

Ribeirão Preto

Bauru

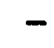

São José do Rio Preto

Araçatuba

26

Presidente Prudente

3.

Marília

$\begin{array}{ll}- & 22\end{array}$

Vale do Ribeira

- 2

$\begin{array}{ll}7 & 10\end{array}$

T $\mathrm{O}$ T A L

71

240

FONTE: Dados brutos CIAM (1972:5, 6, 7, 8); SES (1975). 
Como se pode observar, o convênio foi bastante res trito, cabendo averiguar a que necessidades previdenciārias correspondem a instalação em determinados municípios. A re gião da Grande São Paulo onde se concentra a maior parte da população previdenciária contava com 90 Centros de Saúde lí gados ao Convênio; enquanto São José do Rio Preto com 26, quando esta é caracterizada como uma das regiões com maior população agrícola ou essencialmente rural (SEP, 1976; SUSAM, $\mathrm{s} / \mathrm{d})$, Vale do Paraíba e Bauru, consideradas regiões industriais, contavam com um nümero insignificante de unidades li gadas ao convênio, lembrando, também, que, somente em 1974, - FUNRURAL incorporou-se ao INPS.

o nümero de atendimentos mensais previstos variava de 400 a 1200 e conforme municipios. Dos 460 servidores con tratados para diferentes funções, 75,2\% destinavam-se aos 3 hospitais previdenciários Brigadeiro, Ipiranga e Heliópolis, $17,6 \%$ aos postos de assistência na Capital, 1,7\% às agên cias de São Sebastião, Registro e São José do Rio Preto, 2,4\% ao C.S. Pindamonhangaba e os restantes a serem distribuidos (CIAM, 1972).

De 1971 a 1974, O CIAM atendera 1.737 .629 pessoas sendo $46,4 \%(806.813)$ segurados e 53,6\% (930.816) dependertes Dessas, $1.335 .202,88,4 \%$ tiveram seus casos resolvidos em ni vel de Centros de Saúde; 9,3\% encaminhados a especialistas e 1,6\% hospitalizados, não havendo dados para os encaminhados a exames complementares, em 1974 (SES, 1975).

Em relação aos encaminhados, nos anos de 1972 a 1974, é interessante observar seu crescimento e sua partici- 
pação no total geral, Tabela 22, verificando-se o aumento de participação entre 1972/73, respectivamente 15,6\% e 24,4\%. Em 1974, a falta de dados para exames complementares distor ce essa participação. Observa-se também, um aumento de par ticipação deste tipo de encaminhamento nos dois anos, de caindo aqueles para especialistas e hospitais.

TABELA 22 - Casos encaminhados e total geral de assistência prestada, CIAM, 1972/74

\begin{tabular}{lrrrrrr}
\hline \multicolumn{1}{c}{ Ano } & \multicolumn{2}{c}{1972} & \multicolumn{2}{c}{1973} & \multicolumn{2}{c}{1974} \\
Encaminhamento & No & $\%$ & No & $\%$ & No & $\%$ \\
\hline Exames Complementares & 13.523 & 50,5 & 66.173 & 52,9 & - & - \\
Especialistas & 10.771 & 40,2 & 49.218 & 39,4 & 101.113 & 86,6 \\
Hospitais & 2.505 & 9,3 & 9.661 & 7,7 & 15.696 & 13,4 \\
\cline { 2 - 7 } & 26.799 & 100,0 & 125.052 & & 116.809 & \\
Sub total & \multicolumn{2}{c}{15,6} & 24,4 & & -- & \\
\hline
\end{tabular}

FONTE: SES (1975: anexo)

"... As receitas auferidas, no período, pelo CIAM, elevaram-se de $\operatorname{Cr} \$ 4.823 .899,20$, em 1972 para $\operatorname{Cr} \$ 56.202 .253,80$, em 1974; os resultados financeiros, no período, subiram de Cr\$1.303.902,14 para Cr\$8.124.779,25 ..." (SES, 1975:108)

Em 1976, entre as atividades sistemáticas desenvol vidas pelo governo estadual, destaca-se "... o início de construção de 142 unidades sanitárias e as novas entabulações sobre o convênio com o INPS, objetivando a criação de um me canismo de atendimento nos Centros de saúde ..." (MARTINS, $1976: 24)$. 
No mesmo ano, considerava-se "... um êxito a experiência pioneira do CIAM ..." (SAUDE, 1977b:5) mostrando que, de 1972 a 1976, os Centros de Saúde prestaram 5.952.241 aten dimentos dos quais 608 na área da Grande são Paulo ... os la boratórios Adolfo Lutz realizaram 491.011 exames complementa res. Daquele total, apenas $8 \%$ não tiveram seus problemas re solvidos na própria unitária sanitāria ...". Nesse mesmo ano, planejava-se a reformulação do sistema, "... visando à completa integração das atividades próprias do Centro de Saú de e do atendimento aos previdenciārios. A jornada de traba lho das unidades cobrirá os dois periodos anteriormente re servadas para atividades separadas ..."

Esses dados comprovaram a afirmativa anterior de que a ação da Secretaria permitiu à Previdência bloquear par cela de sua demanda, assim como, possibilitou os encaminhamen tos, não só para os órgãos públicos como privados, se se le var em conta o sistema de diferentes tipos de contratos, es tabelecidos pela Previdēncia com a rede privada.

Não há dados disponíveis sobre o real funcionamento das unidades, em dois turnos. Em geral, a assistência mé dica, prolongava-se por um período de duas horas, servindo pa ra complementar os salários de médicos (31), um dos fatores prioritários no convênio com a Previdência, levantados em 1978, na discussão sobre Política Nacional de Saúde pelo Con selho Estadual de Saúde, como se verá posteriormente.

A politica de integração já se coloca, em 1969, uma vez que, segundo o Decreto no 52.182 de 16 de junho de 1969, (31) Comunicações pessoais. 
a atribuição da Secretaria era "... estudar, planejar, orien tar, coordenar, supervisionar em todo território do Estado, medidas visando à melhoria das condições sanitárias da população, promovendo a saúde, prevenindo a doença bem como participar das medidas de recuperação de saúde ..." (SES, 1972: 9) ou mesmo antes.

Dentro dessa atribuição e ao estabelecer sua política de saūde, assinalava como um dos objetivos"... melhorar - rendimento do sistema de assistência médica, aperfeiçoando o sistema de colaboração técnica e financeira com institui ções privadas, ampliando e melhorando a assistência médicahospitalar ao doente mental definindo adequadamente as condi ções que tornem necessāria a atuação supletiva do Estado,coor denando atividades oficiais e privadas ..." LESER et alii (1968:7)

Não é sem sentido que as primeiras leis aprovadas referem-se à ārea de saúde mental, ārea sujeita a uma Comissão Parlamentar de Inquérito,como já referida. A Secretaria, portanto, apenas se reorganiza para viabilizar uma série de interesses internos e externos, que se encontravam incorpora dos às suas atividades de assistência médica-hospitalar. Ela, realmente, aperfeiçoa como se propõe "... o sistema de colaboração tēcnica e financeira com as instituições privadas ...", ampliando-se os convēnios com hospitais privados na área de saúde mental, assim como outros tipos de convênios.

A Tabela 23 mostra o número de convênios em vigor, em 1974, não implicando como ressaltam GonçALVEs et alii (1974) que o valor do convênio figure no orçamento da unida- 
de orçamentāria.

TABELA 23 - Número de convēnios em vigor, por unidade orçamen tária, Secretaria de Estado de São Paulo, 1974

\begin{tabular}{lrr} 
Unidade orçamentária & No & \% \\
\hline Administração Superior e da Sede e diversos & 31 & 16,0 \\
$\begin{array}{l}\text { Coordenadoria de Serviços Técnicos Especia- } \\
\text { lizados }\end{array}$ & 3 & 1,6 \\
Coordenadoria de Assistência Hospitalar & 53 & 27,5 \\
Coordenadoria de Saúde Mental & 61 & 31,6 \\
Coordenadoria de Saúde da Comunidade & 45 & 23,3 \\
& & 193 \\
\hline T T A L & 100,0
\end{tabular}

FONTE: GONÇALVES et alii (1974:139)

Observa-se que dos 193 convênios, 31,68 ocorrem no âmbito da saúde mental e, principalmente, convênios com hos pitais e sanatórios para manutenção e tratamento de doentes mentais (40 convênios), sendo o restante com Escolas Médicas para uso de hospitais da Coordenadoria, assistência ambulato rial e participação no Programa de Saúde Mental. Em 1967, a Secretaria dispunha de 461 leitos conveniados, passando pa ra 2.410, em 1970 (SES, 1971). Em 1974, o convênio com 40 entidades ampliou para mais de 3.958 leitos (31 convênio com 3.958 e 9 convênios sem especificação de leitos), segundo GONÇALVES et alii (1974). Em 1976, são renovados 39 convēnios com entidades psiquiátricas filantrópicas.

Dos 53 convênios, com a Coordenadoria de Assistēncia Hospitalar sobressaem aqueles referentes à internação e 
tratamento de doentes (18), diagnóstico precoce de câncer gị necológico (13), formação de auxiliares de enfermagem (7) e administração e cessão de hospitais (7), além de outros (8).

Na Coordenadoria da Saúde da Comunidade, dos 45 convēnios, 19 referem-se a consultório dentário, 9 a Centros de Saúde-Escola, 5 a instalação, funcionamento e construção de Unidades Sanitárias; sendo o restante bastante diversificado desde serviços de saúde pública, fiscalização das pro fissões e de entidades veterinárias, realização de trabalhos de estatistica (GONÇALVES et alii, 1974).

Os referentes à Administração Superior destinavamse a acordos internacionais e/ou federais que, também, envol viam as diferentes Coordenadorias e, provavelmente, os novos órgãos criados, (Fundação do Remédio Popular (FURP), Laboratōrios de Vacinas S/A (BRASVACIN) e Superintendência de Sạ neamento Ambiental (SUSAM).

A análise sobre a reforma, realizada por SÁ (1975), GONÇALVES et alii (1974) e TANAKA (1982), revela que a refor ma não conseguiu se implantar, embora considerasse que, apesar das dificuldades "... pode-se considerar já uma realidade a Reforma Administrativa da Pasta ..." (SES, 1975: 113) GONÇALVES et alii $(1974: 134,135)$ afirmam que a "... a admi nistração estadual em macro-estrutura ou não implataram suas reformas ou adotaram figuras juridicas novas e assumiram pa péis diversos e desarticulados para o setor saúde ... em que se pode dizer que a reforma não foi tocada nem para desmanchā la nem para completar sua implantação ...", assinalando "... a dispersão de medidas tomadas dentro e fora da Secretaria,a 
modernização de outras áreas com atuação no setor saúde ... sob a justificativa de maior flexibilidade e a decisão política de impulsionar, prioritariamente, equipamentos sofisticados e de efeito-demonstração tais como Instituto do coração, dos Ambulatórios e a Fundação de oncologia ..."

Essas considerações, contudo, devem ser vistas com ressalvas, pois tratam de "... comparações entre o ser e o dever-ser onde a prática dominante é confrontada com suas de ficiēncias, suas lacunas, permanecendo, no entanto, duvidosa a relevância política de tais indicações ..." como assinala OFFE \& LENHARD $(1984: 13)$.

A pergunta que se coloca, como ressalta o mesmo au tor, é "... como surge a politica de saúde a partir de pro blemas específicos de uma estrutura econômica de classes, bạ seada na valorização do capital e do trabalho assalariado lí vre e quais são as funções que lhe competem, considerando es sas estruturas ..." (OFFE \& LENHART, 1984:13, 14).

E evidente que, dentro deste ponto de vista, a re forma concretiza-se dentro de uma política de saúde nacional e estadual, de privilegiamento do setor privado e os dados demonstram o papel da Secretaria no repasse de recursos pú blicos, fenômeno que sempre a caracterizou, principalmente, quanto à assistência médica-hospitalar. Assim como concre tizou a incorporação dos sanitaristas, que se incluem entre os chamados tecno-burocratas, da década de 1970.

Realmente, os anos recentes são poucos para ava liar uma reforma, aquilo que "... foi o sonho dos sanitaristas que há mais de três décadas vêm procurando retirar as ati 
vidades de saúde pública ... da estagnação anterior onde não havia planejamento geral mas improvisação de última hora, on de existia a avaliação mas apenas estatisticas de : produção sem qualquer valor científico e que eram apresentadas para justificar despesas ou apelos emotivos. Fazem exceção nesse quadro negativista as campanhas de erradicação ou controle de doenças..., através de combates ao vetor ou as campa nhas de imunização contra determinadas doenças transmissíveis ..."(MASCARENHAS, 1973:444)

Contudo, aquilo que foi o sonho dos sanitaristas par mais de vinte anos, implantado por um decreto-lei, já não corresponde mais às novas condições do desenvolvimento capitalista e às novas bases de legitimação que o regime político necessitava.

Em 1970, o próprio Plano Decenal para as Américas demonstra que o sonho acabara ao propor a extensão de cobertura ou, mesmo antes, quando os recursos financeiros externos deslocam-se para a área de assistência médica. Em meados da dećada de 70, a Secretaria vai adequar-se à Politica Nacio nal de Saúde, do II PND, (1975/1979), resultante de um momen to de grandes mobilizações da sociedade brasileira e em que - regime militar busca novas bases legitimação e sua defesa através da Políticas Sociais, principalmente, como no Estado Novo, pela Previdência Social, cuja função era de integrar setores da população crescentemente marginalizados do sistema político e de dar-lhes um sentimento de ser parte dele, como demonstram PIVEN \& CLOWARD (1972), analisando os programas de bem-estar-social. 
Em 1972, a taxa de expansão do setor mais dinâmico da economia, o setor de bens de consumo duráveis, começou a mostrar tendências decrescentes. Ao contrário da produção de bens de capital, esse setor é incapaz de se auto-sustentar, exigindo mecanismos de crédito e financiamento mais amplos e de concentração de renda. Numa fase de economia mundial recessiva, em 1976, o governo ativou um grande nümero de em preendimentos privados no setor de insumos e bens de capital, favorecendo setores financeiros internacionais e setores do mésticos ligados à produção de bens de capital. Com essa po lítica, deflagrou divergências entre os interesses da burgue sia, jā detectadas em 1973, quando se encerrou o período ex pansivo da economia brasileira. Ao mesmo tempo, a manipula ção de índices salariais no mesmo ano e o processo eleitoral mobilizaram grande parte da sociedade brasileira, em que se contestou não só a política econōmica como a estrutura de pô der. Em 1978, após 10 anos, ocorreram as primeiras greves nos setores mais dinâmicos da economia, resultantes de gre ves parciais, paralisações setoriais e "operação tartaruga", ocorridas entre 1973 - 1978. As greves operárias sucederamse as greves do funcionalismo público e os movimentos sociais urbanos contra o custo de vida, a favor de creches, de habitações, de anistia. E, dentro deste contexto, que surgem os movimentos em saúde.

Foi a esse movimento social que respondeu o II $\mathrm{PND}$, que colocou entre outros objetivos a realização de uma política de melhoria de distribuição de renda pessoal e regional. 
cial, canal quase exclusivo da relação governo e classes trá balhadoras. Desmembrando do Ministério do Trabalho, o gover no instituiu o Ministério da Previaência e Assistência So cial (MPAS). Ao mesmo tempo, criou o Conselho de Desenvolvi mento Social, em 1974, composto dos Ministérios do Trabalho, Saūde, Previdēncia e Interior, além do Planejamento, com a finalidade de assessorar o Presidente na formulação de uma po litica social.

No mesmo ano, '1974, criou-se um mecanismo financei ro - Fundo de Apoio ao Desenvolvimento Social (FAS), com a finalidade de agilizar a destinação de recursos financeiros a projetos, envolvendo os setores público e privado. Estabe leceu o Plano de Pronta Ação (PPA), com objetivo de tornaros serviços mais acessíveis aos previdenciários, determinanảo que os casos de urgência deveriam ser atendidos tanto pela rede estadual como privada, independente de vinculação com a Previdência. Ampliou, assim, a extensão de cobertura en quanto criou mecanismos de controle de contas hospitalares e organizou a vinculação do setor público e privado, inclusive com áreas de ensino médico.

o Conselho de Desenvolvimento Social, criado em 1974,"... resolveu que se impunha transformar o sistema es pontâneo existente de fato, em Sistema Nacional de Saúde or ganizado ... evitando que os assuntos de saúde continuassem a ser tratados sem coordenação para diferentes órgãos e instituições do setor público e privado, criando ora ações con correntes numa mesma área, ora ausência em outras ... além de formas distorciadas das atividades ..." (MS, 1979:22) 
O Sistema Nacional de Saúde, criado pela Lei 6229 de 17 de junho de 1975, estabeleceu "... de forma sistêmica, - campo de ação na área de saúde dos setores público e priva do ..." (MS, 1979:22). Com isso, em 1976, nova organização foi dada ao Ministério de Saúde, responsável pela Política Na cional de Saúde.

As áreas programāticas do novo Ministério de Saúde eram:

1. Controle de erradicação de doenças transmissí veis, compreendendo programas nacionais de vigi lância epidemiológica, de controle de doenças (imunização e controle de doenças específicas)

2. alimentação e nutrição

3. pesquisa científica e tecnológica

4. prestação de serviços médicos-assistenciais,com preendendo rede básica de saúde (sistemas inte grados de saúde, ampliação de serviços em áreas de valorização econōmica, plano básico de ação sanitária no Nordeste, interiorização das ações sanitárias, proteção materno-infantil, saúde mental e controle de câncer, etc..) (MS, 1979)

Programas estes que serão incorporados pelo gover no estadual, dentro de sua estratégia governamental em 1976 com "... a montagem do programa de atendimento integral à gestante, à nutriz e ao pré-escolar importante trabalho intersecretarial, montado em detalhe, em 1975 ..." (MARTINS, $1977: 20$ )

(32) Para avaliação dos programas de assisténcia à criança, no Estado de São Paulo, v. TANAKA (1982). 
Somente em 1978 e sob solicitação de uma comissão do Ministério da Saúde e do MPAS, sobre operacionalização do SNS e a viabilidade de implantação de programação integrada, a Secretaria designou una Comissão do Conselho Estadual de Saúde e técnicos da Secretaria, Prefeitura e INAMPs para co mentar e sugerir propostas relativas a Politica Nacional de Saúde.

Neste ano, as propostas voltaram a ser repensadas, "... quando os movimentos reivindicatórios dos médicos e ou tros profissionais de saúde quase levaram ao caos a presta ção de serviços de saúde a população ...

Contudo, não só o momento é outro, como em torno da Saúde e da Previdência giram interesses diversos, mais com plexos como bem colocado pelo documento do Conselho Estadual de Saúde ao abordar o problema da implantação de programação integrada de saūde, "... considerou-se como opção políticajá estabelecida, o caráter multiinstitucional e não monopolísti co do setor saúde, compreendendo órgãos subordinados a vá rios Ministeŕios, várias Secretarias de Estado e de Município - integrado, ainda por agência de caráter beneficiente ou filantrópico, por profissionais liberais e por empresas de caráter lucrativo. As dificuldades institucionais em con seguir a integração decorrem, principalmente, dos obstáculos politicos às diferentes alternativas de subordinação entre as instituições ..." (SES, 1978:3).

o documento enuncia os mecanismos legais existentes

(33) Comunicações pessoais 
para integraçāo como:

- Lei Federal n8 6.259 de 03 de outubro de 1975, Decreto Federal no 78.231 de 12 de agosto de 1976 e Portarias Ministeriais que dispõem sobre a organização das ações de vigilância Epidemioló gica e Programa Nacional de Imunizações, bem co mo Resolução SS no 42 de 12 de outubro de 1977 que regulamenta o credenciamento de Postos de Va cinação no Estado de São Paulo;

- Decreto Estadual no 9.294 de 17 de dezembro de 1976, que estabelece facilidade para o entrosamen to Secretaria da Saúde - Prefeituras Municipais (fornecimento de medicamentos, vacinas e suplemen tos alimentares);

- Portarias do Ministério da Previdência e Assistên cia Social que estabelecem normas de convénios a serem celebrados entre as instituições de previdência social e os governos estaduais e munici pais e outros órgãos públicos;

- Resolução da Secretaria do Planejamento criando Fundos Especiais de Despesa nos Hospitais da Secretaria da Saúde, permitindo convênios com INAMPS, IAMSPE e Prefeituras Municipais;

- Normas do Conselho Estadual de Auxílios e Subvenções para concessão de auxílios e subvenções aos hospitais; assim como, os convēnios existentes na secretaria entre esta e diferentes ōr gãos como:- 
- O Ministērio da Previdência e Assistência Social criando o CIAM, objetivando a integração de serviços médicos no Estado de São Paulo;

- as Prefeituras, nos moldes do Convēnio realizado com a Prefeitura de São Paulo;

- as Prefeituras Municipais para a criação dos Pos tos de Assistēncia Médico-Sanitária (PAS);

- O INPS e os Hospitais-Escolas;

- as Escolas de Auxiliares de Enfermagem;

- as Faculdades de Medicina e Faculdade de Saúde Pública para operação de Centros de Saúde-Escola e Hospitais de Ensino;

- os Hospitais Psiquiátricos e Hospitais Gerais fi lantrópicos e lucrativos;

- o Centro de Controle de Zoonoses da Prefeitura de São Paulo, o Ministērio da Saúde e a OPS;

- Superintendência de Controle de Endemias - SUCEN as Prefeituras Municipais e o Fomento de Urbanização e Melhoria das Estāncias - FUMEST;

- a Prefeitura de São Paulo para fiscalização dos estabelecimentos que comercializam alimentos.

Quanto aos recursos: financeiros para operação-sistema são feitas duas proposições:

a) a curto prazo, dinamização do CIAM, "... que traria, de imediato, substancial apoio financei ro do INAMPS à Secretaria; propõe-se que tais rẹ cursos deveriam ser aplicados prioritariamente na contratação e treinamento de recursos huma 
nos e, sempre que possivel, na melhoria dos ní veis salariais ..." Ressalta que "... a atual tendência do CIAM, de investimentos em reformas, ampliação e equipamentos de Centros de Saúde, deveria ser revista, considerando-se que o ele mento humano é o instrumento mais importante pa ra as ações de saúde, principalmente quando se pretende a adoção de técnicas mais simplificadas ..." (SES, 1978:10) ou seja uma extensão de cobertura com atenção primária à saúde. Além da dinamização do CIAM, propõe-se a regionalizą ção deste, de acordo com a Divisão Regional de Saúde e dos Fundos Especiais de Despesas, recen temente criados nos Hospitais estaduais (SES, 1978) .

b) a longo prazo, a constituição de um Fundo ou uma Fundação Estadual de Saúde, projeto que se con cretiza, no mesmo ano: a criação do FUNDES.

Em relação à prestação de serviços, o documento propõe a integração regionalizada e hierarquizada em diferen tes níveis de complexidade, evitando-se a dicotomia e separa ção entre as redes de assistência médica-sanitāria e médica hospitalar. A rede básica de assistēncia médica-sanitária com preenderia as unidades de assistência primária de dois níveis: "... 1) Postos, operados por auxiliares (com treinamen to específico e supervisão continuada), podendo ou não, rece ber periodicamente um médico geral e 2) Centros de Saúde, executando as atividades dos postos, acrescidas de assistência médica permanente, colheita de material para exames e 
Vigilāncia Epidemiológica. De acordo com tamanho dos municí pios, o atendimento de urgência seria assumido, em primeira instância, pela prōpria rede básica, encaminhando-o a hospitais gerais ..." (SES, 1978:13).

Depois de diagnosticar as caracteristicas da rede hospitalar "... público isoladamente sem condições de operar diretamente ou opera com capacidade ociosa e alto custo de manutenção ...", falta de planos tanto do governo estadual e federal para ampliação de rede; o peso das beneficientes e filantrópicas "... com intensa participação da comunidade ..." (SES, 1978:17, 18) e do setor lucrativo; financiamento hospitalar predominantemente $(80 \%)$ com recursos do INAMPS, o documento propõe: 1) a integração por sete áreas programáti cas (tuberculose, hanseníase, etc...); 2) construção e ampliação de hospitais com recursos públicos (FAs, Comissão Es tadual de Auxílio e Subvenções - CEAS); 3) Utilização dos leitos privados "... condicionada à utilização máxima dos leitos da rede pública, e em se tratando de rede privada, a prioridade deverá ser a utilização dos beneficientes ou filantrópicos ..." Tambēm ressalta "... a necessidade de nor mas e procedimentos de internação, definidos pelo Conselho Deliberativo para evitar que a rede básica venha a se consti tuir em fonte agenciadora de internação remunerada pelo sis tema de pagamento por unidade de serviço ..." (SES, 1978:19) A utilização das filantrópicas e a necessidades de normas e procedimentos para internação resultam, provavelmente, de uma estratégia frente ao setor mais empresarial. 
cações sócio-políticas da sociedade brasileira após o ciclo econômico expansivo de 1969/1973 e recessivo pós-74, como já assinalado anteriormente e colocam questões mais complexas, para Secretaria, na década seguinte, onde "... tudo se transforma mas a misēria permanece e a precariedade dos serviços debilita a consolidação normativa ..." (ANDRADE, 1982: 111) 


\section{CONCLUSŨES}

No presente trabalho, procurou-se analisar a Saúde Pública como uma prática social dentro de uma formação sô cial capitalista tardia e dependente.

Observou-se que, dadas às especificidades do desen volvimento capitalista no Brasil, a Saúde Pública, como par te constituinte de um Estado, foi se implantando conforme o grau deste desenvolvimento. Algumas de suas atividades já se delineavam nos séculos anteriores, correspondendo ao grau de desenvolvimento vigente e à situação de subordinação polí tica ao dominio português. Em decorrência disto, grande par te de suas atividades, sem muita especificidade, ficava sob responsabilidade de associações privadas, filantrópicas e/ou religiosas e englobadas às outras atividades assistenciais. Ressalte-se, contudo, que estas associações sempre contaram com auxilios e recursos financeiros estatais.

Constatou-se que, na medida em que se intensificou - processo de desenvolvimento e sob o impacto do capitalismo internacional numa outra fase, a Saúde Pública passou a de sempenhar um importante papel no processo de circulação de mercadorias, inclusive da mão-de-obra estrangeira. Foi, sob imposição de organismos internacionais, como a Fundação Rockfeller e, posteriormente, da Organização Panamericana de Saúde, que a Saúde Pública procurou organizar-se em um âmbito nacional de atuação, e dentro de um processo de implantação de um Estado burguēs. Nesta, ela adquiriu uma especifi- 
cidade como área de atuação estatal - o controle de doenças coletivas. Observou-se que, dadas as caracteristicas do Es tado brasileiro, federativo mas essencialmente unitário, e dos regimes politicos, a centralização e o autoritarismo mar caram a Saúde pública por um longo período.

Verificou-se uma estratégia sempre presente na in corporação de áreas de atuação, compreendendo a mobilização de classes por meio de reuniōes, intensa propaganda e divulgação, formação de ligas, de cuja direção participavam ele mentos do aparelho estatal. A mobilização foi sempre seguida da implantação no aparelho de estado de um tipo de organi zação provisōria, as Comissões e, dependendo das forças polí ticas (internas e externas ao aparelho estatal), a problemática era formalmente incorporada na estrutura técnico-burocrá tica. Portanto, convertendo o controle de doenças em objeto da atividade estatal, a burocracia subtraia a problemática, do âmbito das relações de classes, passando a organizá-la e controlá-la, de acordo com os interesses de classes e frä ções de classes, ligados à questão estando estes presentes no próprio aparelho estatal ou fora dele. Há, portanto, uma interrelação de interesses públicos e privados.

Verificou-se que a ampliação ou não de uma área na estrutura burocrática dependeu de um jogo de interesses polí ticos, inclusive internacionais, e que, nesta ampliação, hou ve uma seletividade quanto às doenças a serem incorporadas co mo objeto de atuação estatal, incluindo preferencialmente al gumas (febre amarela, malāria, etc..) e, subvalorizando ou tras (tuberculose, lepra, etc..) que atingiam uma grande par 
cela sem no entanto englobar todas as classes de maneira igual. Em sintese, observou-se que, a partir de uma maior definição como área de atuação própria no aparelho estatal, separada de outras atividades assistenciais, a Saúde pública implantou-se, criando, com suas atividades, estruturas técni co-burocrāticas, por meio das quais divulgaram-se idéias, es tabeleceram-se regras e normas legais. Concomitantemente des tinavam-se recursos financeiros iniciais para essa implantação e organizavam-se outras formas de captação dos mesmos que possibilitavam sua participação no circuito do consumo de alguns bens. Esse substrato material possibilitou a sedimen tação da Saúde Pública e deu-lhe a legitimidade para imporse, inclusive de maneira coercitiva, frente à sociedade, via bilizando os diferentes interesses de classes. E na negação das contradições sociais (que determinam o aparecimento das doenças), na impossibilidade de solucionar os problemas, ge radores de doenças e, portanto, de proporcionar saúde, que a Saúde Pública afirma-se. 


\section{REFERENCIAS BIBLIOGRAFICAS}

AID (AGENCY FOR INTERNATIONAL DEVELOPMENT) - Desenvolvimento de comunidade. São Paulo, Sociologia e Política, 1964.

ALMEIDA, A.S. - A integração do hospital na saúde pública. Rev. Serv. Esp. Saúde púb., Rio de Janeiro, $\underline{9}(2): 206-14$, 1957.

ALVES, A.C. - Estado e ideologia; aparência e realidade. São Paulo, Brasiliense, 1987.

AMADO, A. - A política da tuberculose na formação industrial de São Paulo. São Paulo, 1985. (Dissertação - Mestrado Faculdade de Medicina da USP) .

AMIN, S. - o desenvolvimento desigual. Rio de Janeiro, Forense Universitária, 1976.

AMMANN, S.B. - Ideologia do desenvolvimento de comunidade no Brasil. São Paulo, Cortez, 1985.

ANDRADE, R.C. - Política social e normalização institucional no Brasil. In: MAIRA, L. et alii - América Latina: novas estratégias de dominação. 2a. ed. São Paulo, Vozes. CEDEC, 1980. p. 87-114.

ANUARIO ESTATISTICO DO BRASIL (1949) - Instituto Brasileiro de Geografia, Estatistica, Rio de Janeiro, 1950. p.442-5. 
ARQUIVOS DE HIGIENE, São Paulo, $1(1): 41-4,1936$.

$$
\begin{aligned}
& , \underline{5}(8): 336-7,1940 \mathrm{a} . \\
& , \underline{5}(8): 339-44,1940 \mathrm{~b} . \\
& , \underline{5}(10): 285-8,1940 \mathrm{c} . \\
& , \underline{10}(23): 150-4,1945 . \\
& , \underline{25}(83): 5,1960 . \\
& , \underline{27}(91): 93-4,1962 \mathrm{a} . \\
& , \underline{27}(91): 92-4,1962 \mathrm{~b} .
\end{aligned}
$$

ARRUDA, M.O. - Relatório da Inspectoria de Hiḡiene da Provín cia de São Paulo, correspondente ao anno de 1886, dirigido a Exa. Inspectoria Geral do Império, em 19 de janeiro de 1887. Arch. Hyg., São Paulo, $1(1): 89-104,1936$.

BARROS, A. - Plano de desenvolvimento integrado: (PLADI); go verno Adhemar de Barros, 1964/1966. São Paulo, Imprensa Oficial do Estado, 1964.

- Mensagem apresentada pelo governador Adhemar de Barros à Assembléia Legislativa do Estado de São Paulo, em 14 de março de 1964. São Paulo, Imprensa Oficial do Esta do, 1965 .

BARROS BARRETO, J. - Bases para organização da luta anti-tuberculose em face ao momento epidemiológico atual. Arq. Hig., Rio de Janeiro, $10(1): 7$ a 79, 1940 . 
BARROS BARRETO, J. - A organização da saúde pública no Brasil. Arq. Hig., Rio de Janeiro, $12(2): 169-215,1942$.

BERLINCK, C. - A Escola de Sociologia e Política no XXV aniversārio (1933-1958). Sociologia, S. Paulo, 20 (2):127-35, 1958.

BERNIS, G.C. - Economia e saúde. Rio de Janeiro, PESES/PEPDE' ENSP, s.d. (Texto de Apoio no 7).

BLOUNT, J.A. - A administração da saúde pública no Estado de São Paulo: o serviço sanitārio 1892-1918. Rev. Adm. Emp., Rio de Janeiro, $12(4): 40-8,1972$.

BOBBIO, N.; MATTEUCCI, N.; PASQuiNo, G. - Dicionário de polí tica. Brasilia, Editora da Universidade, 1976. p.579-81. - Estado, governo, sociedade; para uma teoria ge ral da política. Rio de Janeiro, Paz e Terra, 1987.

BOLETIM DA ASSOCIAÇÃO BRASILEIRA DE EDUCAÇÃO MEDICA, Rio de Janeiro, $\underline{18}(3): 4,1986$.

BOLETIM INFORMATIVO ASSOCIAÇÃO DOS MÉDICOS SANITARISTAS, São Paulo, (6):3-6, 1980 .

BOLETIM DE LA OFICINA SANITARIA PANAMERICANA, Washington, D. C. , $\underline{42}(1): 6-21,1957$. 
BOLETIM DE LA OFICINA SANITÁRIA PANAMERICANA, Washington, D. C. , $54(3): \underline{266}, 1963 a$.

- $\underline{56}(2): 179,1963 \mathrm{~b}$.

- $\underline{57}(3): 293,1964$.

BRAGA, J.C.S. \& PAULA, S.G. - Saúde e previdência; estudos de politica social. São Paulo, CEBES-HUCITEC, 1981.

BRUNHOFF, S. - Estado y capital. Madrid, Villalar, 1978.

CAMPELLO DE SOUZA, M.C. - Estado e partidos políticos no Brasil (1930 a 1964). 2ąed. São Paulo, Alfa-Omega, 1983.

CARDOSO, F.H. - O modelo político brasileiro e outros ensaios. São Paulo, Difusão Européia do Livro, 1972.

- Partidos e deputados em São Paulo: o voto e a representação política. In: LAMOUNIER, B. \& CARDOSO, F. H., ed. Os partidos e as eleições no Brasil. Rio de Janeiro, CEBRAP/Paz e Terra, 1975. p.45-74. - Dos governos militares a Prudente-Campos Sa les. In: FAUSTO, B., org. O Brasil republicano. 2aed. São Paulo, DIFEL, 1977. v.3, p.13-50.

CARLos, F. - A saúde pública no plano de ação. Arq. Hig., S. Paulo, 23/4:75-82, 1958/1959. 
CARLOS, F. - Atividades da secretaria da Saúde Pública e da Assistência Social em 1959. Arq. Hig., S. Paulo, 25 (83): $41-54,1960$.

- Atividades da Secretaria de Saúde Pública e As sistência Social em 1961. Arq. Hig., S. Paulo, 27(91):7380,1962 .

CARVALHO PINTO, C.A. - Mensagem apresentada pelo governador Carlos Alberto de Carvalho Pinto à Assembléia Legislativa de São Paulo, em 14 de março de 1959. São Paulo, Imprensa Oficial do Estado, 1959.

CIAM (CENTRO DE INTEGRAÇÃO DE ATIVIDADES MÉdICAS) - Relatório anual de atividades; exercício de 1972. São Paulo.

CLEAVER, H. - A economia política e saúde pública e a maläria. Rio de Janeiro, PEC/ENSP/ABRASCO), 1984. p.133-79. (Texto de apoio, Ciēncias Sociais 2).

CLOWARD, R.A. \& PIVEN, F.F. - The professional bureaucracies: benefit systems as influence systems. In: PIVEN, F.F. \& CLOWARD, R.A. The politics of turmoil, essays on poverty, rare and urban crises. New York, Pantheon Books, 1974. p. 7-25.

COHN, A. - Previdência social e processo politico no Brasil. São Paulo, Moderna, 1980.

CORDEIRO, H.A. - As empresas médicas; as transformações capi talistas da prática médica. Rio de Janeiro, Graal, 1984. 
CosTA, N.R. - Lutas urbanas e controle sanitário. Rio de Ja neiro, Vozes, 1985.

CUNHA, M.W.V. - O sistema administrativo brasileiro: 1930 1950. Rio de Janeiro, Centro Brasileiro de Pesquisas Edū cacionais, Instituto Nacional de Estudos Pedagógicos. Mi nistério de Educação e Cultura, 1963. (série VI - Sociedade e Educação).

DIAS, I.M. - A história da psiquiatria no Estado de São Paulo (sob signo da exclusão). São Paulo, 1985. (Dissertação - Mestrado - Faculdade de Medicina da USP).

DIÁRIo OFICIAL, São Paulo, 02 jan. 1952.

, 09 ag. 1952.

, 08 mar 1953.

, 20 fev. 1957

, 15 jan 1958.

, 31 jan 1958.

, 04 fev. 1958.

, 15 fev. 1958.

, 06 mar. 1958.

, 06 mai 1958.

, 24 mai 1958. 
DIARIO OFICIAL, São Paulo, 09 abr. 1958.

, 19 jul. 1958.

, 17 mar 1959.

, 24 mar 1959.

, 08 abr. 1959.

, 17 mai 1959.

, 03 mai 1960.

, 18 mai 1965.

10 mai 1966.

07 nov. 1966.

, 07 jul. 1967.

DONNANGELO, M.C.F. - Medicina e sociedade; o médico e seu mer cado de trabalho. São Paulo, Pioneira, 1975.

- Saúde e sociedade. São Paulo, Duas Ci-

dades, 1976.

- Aspectos da politica social brasileira

e da participação comunitária em saúde, são Paulo, s.d.

ENGELS, F. - A origem da familia, da propriedade privada e

do Estado. Rio de Janeiro, Editorial Vitória, 1964. 
ENGELS, F. - Do socialismo utópico ao socialismo científico. 3a. ed. Lisboa, Editorial Avante, 1975.

EVERS, T. - Sobre o comportamento político das classes médias no Brasil, 1963/1977. In: PEREIRA, L., org. Perspec tivas do capitalismo moderno. Rio de Janeiro, Zahar, 1971. p. $38-57$.

FAUSTO, B. - Pequenos ensaios da história da República: (1988/ 1945). 2ạ ed. São Paulo, Brasiliense, s.d. (Cadernos CE BRAP, 10).

FEE, E. - Disease of discovery: a history of the Johns Hopkins School of Hygiene and Public Health: 1916-1939. Baltimore, The Johns Hopkins University Press, 1987. p.1-95.

FERREIRA, J.R. - La cooperación científico-técnico, universitária en América Latina y la respuesta de los organismos internacionales; (Editorial). Educ. med. y Salud., Washington, DC, $18(1): 1-8,1984$.

FERREIRA, N.G. \& SALUM, E. - Contribuição ao estudo do movimento demográfico-sanitário no interior do Estado de são Paulo em 1951. Arg. Hig., S. Paulo, 18(57):218-66, 1953.

FONSECA FILHO, O. - A Escola de Manguinhos: contribuição pa ra o estudo do desenvolvimento da medicina experimental no Brasil. In: Oswaldo Cruz Monumenta Histórica. São Paulo, 
Graf. "Revista dos Tribunais", 1974. v.2.

FRAIHA, H. - Oswaldo Cruz e a febre amarela no Pará. Belém, Conselho Estadual de Cultura, 1972.

FRANCO-AGUDELO, S. - Saúde e imperialismo: a ação antimalária na América Latina e a Fundação Rockfeller. Rio de Ja neiro, PEC/ENSP/ABRASCO, 1984. p.101-13. (Texto de apoio, Ciências Sociais, 2).

FUNDAÇÃO IBGE - Sinopse preliminar do censo demogrāfico, São Paulo. Rio de Janeiro, 1981 (99 Recenseamento Geral).

FUNDAÇÃO GETULIO VARGAS - CENTRO DE PESQUISA E DOCUMENTAÇÃO DE HISTORIA CONTEMPORANEA (FGV-CPDOC) - Dicionário histórico-bibliográfico brasileiro, 1930-1980. Rio de Janeiro, Forense Universitāria/FINEP, 1984. 4v.

FURTADO, C. - Formação econômica do Brasil. llà ed. São Pau 10, Nacional, 1971.

GAMBETTA, W.R. - Desacumular a pobreza: Santos, limiar do sé culo. Esp. \& Deb., São Paulo, (11):17-27, 1984.

GARCIA, J.C. - Ensaios e políticas da saúde na América Latina. Rio de Janeiro, PEC/ENSP/ABRASCO, 1984. p.13-99. (Textos de Apoio, Ciēncias Sociais, 2). 
GIRALDELLI, B.W. - O coeficiente de separação de óbitos de menores de um ano, São Paulo, 1930/1980. Inf. demog., S. Paulo, (8):70-89, 1983 .

GOMES, A.M.C. - A constituição do homem novo. In: OLIVEIRA, L.L. et alii - Estado Novo; ideologia e poder. Rio de Ja neiro, Zahar, 1982a. p.151-66. - O redescobrimento do Brasil. In: OLIVEIRA, L.L. et alii. Rio de Janeiro, Zahar, 1982b. p.104-50.

GONÇALVES, E.L.; SA, E.N.C.; CAMARGO, G.E.A.; YUNES, J. ; MERCADANTE, O.; PINTO, R.M.G.; QUAGLIA, S.R.; FONSECA, T.F.; ABRAMO, Z.W. - Relatório elaborado pela equipe de saúde. São Paulo, 1974 (mimeografado).

GRAHAM, L.S. - Civil service reform in Brasil. Austin, University of Texas Press, 1968.

GRAMSCI, A. - Introdução ao estudo da filosofia e do materia lismo histórico e a ciência e o príncipe moderno. In: - Obras escolhidas. São Paulo, Martins Fontes, 1978a. p.21-39, 147-236. - Cartas do cárcere no 144. Rio de Janeiro, Civilização Brasileira, 1978b. p.222-5. 
GRAMSCI, A. - A formação dos intelectuais. In:

Os intelectuais e a organização da cultura. 2ą ed. Rio de Janeiro, Civilização Brasileira, 1978c. p.3-23.

HOBSON, W. - Preface. In: - The theory and practice of Public health. 2a ed. London, Oxford University Press., 1965. p.9-11.

HOFFMAN, R. - Tendências da distribuição da renda no Brasil e suas relações com o desenvolvimento econômico. In: TOLIPAN, R. \& TINELLI, A.C., org. A controvērsia sobre distribuição de renda e desenvolvimento. Rio de Janeiro, Zahar, 1975. p.105-21.

IANNI, O. - A formação do estado populista na América Latina. Rio de Janeiro, Civilização Brasileira, 1975. - A classe operāria vai ao campo. São Paulo, lCa dernos CEBRAP, 24). - Revolução e cultura. Rio de Janeiro, Civilização Brasileira, 1983. - Estado e planejamento econômico no Brasil. 4 ạ ed. Rio de Janeiro, Civilização Brasileira, 1986. 
IBGE (INSTITUTO BRASILEIRO DE GEOGRAFIA E ESTATISTICA) - Problemas de base do Brasil. 2a ed. Rio de Janeiro, 1948.

IYDA, M. - Mudanças nas relações de produção e migração: o caso de Botucatu e São Manuel. São Paulo, 1979. (Disser tação - Mestrado - Faculdade de Saúde Pública da USP).

JUNQUEIRA, H.; KFOURI, N.F.; FERREIRA, T.P. - Problemas sociais de alcance regional. Arq. Hig., S. Paulo, 26(90): $271-90,1961$.

KILBOURNE, E.D. - Introduction. In: \& SMILLIE, W.

G. Human ecology and public health and preventive medicine. 4å ed. New York, Macmillan, 1969.

L'ABBATE, S. - Fome e desnutrição: os descaminhos da política social. São Paulo, 1982. (Dissertação - Mestrado-Fą culdade de Filosofia, Ciências e Letras da USP).

LABRA, M.E. - O movimento sanitarista nos anos 20: da conexão internacional à especialização em saúde Pública no Brasil. Rio de Janeiro, 1985. (Monografia, Escola Brasileira de Administração Pública, Fundação Getūlio Vargasł

LAFER, C. - O planejamento no Brasil - observações sobre o Plano de Metas (1956 - 1961). In: LAFER, B.M. Planejamento no Brasil. São Paulo, Perspectiva, 1973. p.29-50. 
LBA (LEGIÃO BRASILEIRA DE ASSISTENCIA) - Relatório das atividades da Comissão Estadual de São Paulo. Mat. e Inf., São Paulo, 16 (1):53-201, 1957 .

LEMOS, M.M. - A Secretaria de Saúde e a realidade sanitária do Estado de São Paulo, São Paulo. Secretaria de Saúde, 1967 .

LENIN, V.I. - o Estado e a revolução. In: - Obras escolhidas. Lisboa/Moscovo, Avante/Progresso, 1978. v.2 p. $218-305$.

LESER, W.; ANTUNES, P.C.A.; MASCARENHAS, R.; PASCALE, H.; TOLEDO PIZA, J.; MELLO, V.H. - Reorganização da Secretaria de Saúde Pública do Estado de São Paulo. In: CONGRESSO BRASILEIRO DE HIGIENE, 16, Salvador, 1968.

LEVY, M.S.F. - O papel da migração internacional na evolução da população brasileira (1872 a 1972). Rev. Saúde públ. S. Paulo, 8 (supl.) $: 49-90,1974$.

LOPES, J.R.B. - Desenvolvimento e mudança social: formação urbano-industrial no Brasil. São Paulo, Nacional/USP. 1968 .

MACCACARO, G. - Clase y salud. In: BASAGLIA, F. et alii. La salud de los trabajadores, aportes para una politica de la salud. México, Nueva Imagen, 1978. p.73-90.

MALLOY, J.M. - Previdência social e classe operária; uma nota de pesquisa. Est. CEBRAP, (15):115-32, 1976. 
MALLOY, J.M. - Política de previdência social no Brasil. São Paulo, Moderna, 1986.

MANHEIN, K. - o homem e a sociedade. Rio de Janeiro, Zahar, 1962.

MARTINS, P.E. - Segunda mensagem anual à Assembléia Legislativa. São Paulo, Impresa Oficial do Estado, 1976. - Terceira mensagem anual à Assembléia Legislativa. São Paulo, Imprensa Oficial do Estado, 1977. - A no 123/77, de 30 de setembro de 1977. In: - Mensagens encaminhadas à Assembléia Legislativa, 1976/1977. São Paulo, Imprensa Oficial do Estado, 1977. v.2, p. 246 . - A no $233 / 78$ de 28 de outubro de 1978. In: - Mensagens encaminhadas à Assembléia Legislativa 1978/1979. São Paulo, Imprensa Oficial do Estado, v.3 p. 1002 .

MARX, K. - Crítica da economia política, (Prefácio). In: - Contribuição para crítica da economia politica. Lisboa, Editorial Estampa, 1971. p.27-31. - O capital, critica da economia política. 2a ed. São Paulo, Civilização Brasileira, 1971b. 2.v, p.23-31. - O 18 Brumário e cartas a Kugelmann. 3ä ed. Rio de Janeiro, Paz e Terra, 1977. 
MARX, K. - Las luchas de clases en Francia de 1845 a 1850.

Moscu, Editorial Progresso, 1979.

\& ENGELS, F. - A ideologia alemã (I Feuerbach). 3ạ ed. São Paulo, Ciências Humanas, 1983.

MASCARENHAS, R.S. - Contribuição para o estudo da administra ção sanitária estadual em São Paulo. São Paulo, 1949. (Tese - Livre-Docēncia - Faculdade de Higiene e Saúde Pública da USP).

- Historia da saúde pública no Estado de São Paulo. Rev. Saüde püblica, S. Paulo, ㅍ:433-46, 1973. MATHIAS, G. \& SALAMA, P. - O Estado super desenvolvido. São Paulo, Brasiliense, 1983.

MELO, M.A.B.C. - A cidade dos mocambos: Estado habitação e lutas de classes, no Recife (1920-1960). Esp. e Deb., S. Paulo, (14):45-66, 1985 .

MELLO, V.H. - Erradicação da malária, nova estratégia na luta anti-malária. Arg. Hig., S. Paulo, 25 (83):7-18, 1960.

MILANO, E.A.; LUCCHESI, B.M.; AYROSA GALVÃO, A.L.; SILVA, M. M.; VALLE, L.R.; MOURA, R.A. - Avaliação dos resultados dé campanha de vacinação contra poliomielite de São Paulo, Brasil. Arq. Hig., S. Paulo, 27 (93):207-22, 1962.

MS (MINISTÉRIO DA SAUDE) - Evolução institucional da saúde pú blica. Brasilia, 1979. 
MONETTI, V. \& SOUTO, C.B. - O papel do Departamento Estadual da Criança no combate à mortalidade infantil no Estado de São Paulo. Arg. Hig., S. Paulo, 25(8):295-300, 1960.

; CARVAlHo, P.R.; MOURA, J.C. de A. - Vacinações na infância. Aspectos técnicos e administrativos dos programas e campanhas desenvolvidas pela secretaria de Saúde do Estado de São Paulo, de 1962 a 1972. Sãn Paulo. Insti tutn de Saūde, Divisão de Saúde Materna e ỏa Criança, 1974. (Publicação, 21, série D, no 7).

\& CARVALHO, P.R. - Mortalidade materna e na infāncia no Estado de São Paulo de 1960 a 1970. São Paulo, Instituto de Saúde. Divisão de Saúde Materna e da Criança, 1975. (Publicação 24, série D, no 8).

MORAIS, J.Q. - A contribuição da LBA na proteção à maternida de e a infāncia em São Paulo. Mater. e Inf., S. Paulo, $\underline{4}$ $(11 / 12): 13-9,1947$.

MULleR, G. - População, emprego e espaço urbano; a dinâmica agrária paulista em 1950/1980. In: ENCONTRO NACIONAL ASSOCIAÇÃO BRASILEIRA DE ESTUDOS POPULACIONAIS, 3. Vitória, 1982. Anais $\cdots$ p. 263-88.

NATEL, L. - Mensagem apresentada pelo governador Laudo Natel à Assembléia Legislativa em 31 de março de 1972. São Pau 1o, Imprensa Oficial do Estado, 1972. p.204. - Mensagem apresentada pelo governador Laudo Natel 
à Assembléia Leqislativa em 31 de março de 1973. São Pau 10, Imprensa Oficial do Estado, 1973. p.203.

OFFE, C. \& LENHARDH, G.H. - Teorias de Estado e política social. In: OFFE, C. - Problemas estruturais do estado capitalista. Rio de Janeiro, Tempo Brasileiro, 1984.

OPS (ORGANIZACIÓN PANAMERICANA DE LA SALUD) - Extensão de cobertura dos serviços de saúde, mediante o uso de estratégias de assistência primária e participação da comunidade Washington, D.C. In: REUNIÃO ESPECIAL DE MINISTROS DA SAODE DA AMERICA, 4, Washington, DC, 1977.

ORTIZ, L.P. - Evolução da mortalidade infantil no Estado de São Paulo, segundo sexo, idade e causas de morte. Inf. demog., S. Paulo, (8):91-136, 1983.

PASCALE, H. - Novos rumos sobre a recuperação do homem rural. Arq. Hig., S. Paulo, 18 (55):3-14, 1953.

PEREIRA, L. - Ensaios de sociologia do desenvolvimento. São Paulo, Pioneira, 1970. p.11-51. - Capitalismo e Saúde. In: - Capitalis mo: notas teóricas. S. Paulo, Duas Cidades, 1977. p.9-36

PIVEN, F.F. \& CLOWARD, R.A. - Regulating the poor: the functions of public welfare. New York, Vintage Books, 1972.

PESSOA, S.B. - Medicina rural e socialização da medicina. In: - Ensaios médico-sociais. Rio de Janeiro, Guanabara-Koogan, 1960. p.181-94. 
POSSAS, C. - Saúde e trabalho; a crise da previdēncia. Rio de Janeiro, Graal, 1978.

POUlANTZAS, N. - Poder politico e classes sociais do estado capitalista. Porto, Portucalense, 1971. 2v. - O Estado, o poder, o socialismo. Rio de Janeiro, Graal, 1980. p.64, 67, 69, 153.

PRADO JR., C. - História econômica do Brasil. 4 ạ ed. São Paulo, Brasiliense, 1956. - Evolução política e outros estudos. 2 à ed. São Paulo, Brasiliense, 1957.

PRADO, W.S. - Aplicação da vacina Sabin no interior do Estado de São Paulo; lạ dose. Arq. Hig., S. Paulo, 27 (94): $353-360,1962$.

PUFFER, R.R. \& GRIFFITH, G.W. - Características de la mortalidade urbana. Washington, DC. Organización Panamericana de la Salud, 1968. (Publicación Científica, 151).

R. NETTO, A. - O caminho para formação do serviço sanitário de São Paulo. Arch. Hyg., S. Paulo, I (14):5-34, 1942.

RAMOS, G. - O problema da mortalidade infantil no Brasil. Sociologia, S. Paulo, (13):1-43, 1951.

RETRATO DO BRASIL - Pouca República depois da monarquia. São Paulo, Politica Ed., 1984. v.1, p.13-6. 
RODEE, C.C.; ANDERSON, T.J.; CHRISTOL, C.Q. - Introdução à ciência politica. Rio de Janeiro, Agir, 1959. v.2, p.207 11 .

RODRIGUES, B.A. - Fundamentos de administração sanitária. Rio de Janeiro, USAID, 1967.

ROSEN, G. - Da polittica médica à medicina social: ensaios so bre a história da assistência médica. Rio de Janeiro, Graal, 1980.

SA, E.N. - Uma experiência da reforma administrativa da Secretaria do estudo de Saúde. São Paulo, 1975. (Disserta ção - Mestrado - Faculdade de Saúde Pública da USP).

SAAD, P.M. - Evolução da população urbana e rural nas onze regiões administrativas do Estado de São Paulo, 1940-1970. Inf. demog., S. Paulo, (1):1-146, 1980.

SALAMA, P. - Estado e capital: o estado capitalista como abs tração real. Est. CEBRAP, Rio de Janeiro, 26:119-56, 1980. SAUDE, São Paulo, (6):1, 1977a. , (6):5, 1977b.

SERRA, J. - Crescimento econômico e condições básicas de vida da população: notas sobre o caso do Brasil. In: ENCON TRO NACIONAL DA ASSOCIAÇÃO BRASILEIRA DE ESTUDOS POPULACIO NAIS, 3, Vitória, 1982a. Anais ... p.51-77. 
SERRA, J. - Ciclos e mudanças estruturais na economia brasileira de pós-guerra. In: BELLUzzo, L.G.M. \& COUTINHo, R., org. Desenvolvimento capitalista no Brasil. São Paulo, Brasiliense, 1982b. p.56-121.

SIMON, M.C. - O positivismo de Comte. In: REZENDE, A., org., Curso de filosofia. Rio de Janeiro, Zahar, 1986. p.12032 .

SINGER, P. - Economia política da urbanização. São Paulo, CEBRAP/Brasiliense, 1973. - Evolução da economia brasileira, 1966-1975. Est. CEBRAP, S. Paulo, (16):61-83, 1976 .

SPOSATI, A. de O. - História da pobreza assistida em São Pau 1o, São Paulo, 1987. (Tese - Doutoramento - Pontifícia Universidade Católica).

STEPHAN, N. - Gênese e evolução da ciência brasileira. Rio de Janeiro, Artenova, 1976.

SEP (SECRETARIA DE ECONOMIA E PLANEJAMENTO) - Primeiro estudo SEMO/SINE/SP, São Paulo, 1976. (Série Estudos e Pesquisa, no 2).

SES(SECRETARIA DE ESTADO DE SAODE) - Relatório de atividades 1967-1970. São Paulo, 1971. (mimeografado).

textos legais e regulamentares, 1967-1970. São Paulo, 1972 
SES(SECRETARIA DE ESTADO DE SAUDE) - Relatório de atividades 1971/1975, São Paulo, 1975. (mimeografado)

- Relatório sobre Política Nacional apresentado ao Conselho Estadual de Saúde, em janeiro de 1978. São Paulo, 1978.

- Relatório setorial do

governo do Estado de São Paulo, 1975-1979. São Paulo, Im prensa oficial do Estado, 1979.

SSPAS (SECRETARIA DE SAÚdE PÚBLICA E ASSISTENCIA SOCIAL) - An teprojeto de Lei. São Paulo, Imprensa Oficial do Estado, 1957 .

SOARES, R. - Campanha de erradicação da variola, vacinação antivaríola em massa da população do Estado de São Paulo; resultados e avaliação. São Paulo, Secretaria de Estado de Saūde, 1971.

SONTAG, S. - A doença como metáfora. Rio de Janeiro, Graal, 1984 .

SUSAM (SUPERINTENDENCIA DE SANEAMENTO AMBIENTAL) - Relatōrio de atividades, 1971/1973, são Paulo, s.d.

TAMEIRÃo, H.P. - Emílio Ribas e Campos de Jordão. Arq. Hig., S. Paulo, $27(91): 67-71,1962$.

TANAKA, O.Y. - Avaliação do programa de assistência à criança da Secretaria da Saúde, São Paulo, 1982. (Dissertação 
Mestrado - Faculdade de Saūde Pública da USP).

TESH, S. - Political ideology and public health in the nineteenth century. Int. J. Hlth. Serv., 12(2):321-42, 1982 .

TEIXEIRA, S.M.F. - Evolução e crise de uma política social. Saúde em debates, Rio de Janeiro, (9):21-36, 1980.

TRUJILLO, A.F. - Pesquisas e publicações nas Ciências Sociais sob a influência da Escola de Sociologia e Política (19331938). Sociologia, S. Paulo, 20 (2):136-47, 1958.

VASQUEZ, A.S. - Filosofia da praxis. 2ą ed. Rio de Janeiro Paz e Terra, 1977.

VIEIRA, E. - Estado e miséria social no Brasil de Getúlio a Geise1, 1951-1978. São Paulo, Cortez, 1983.

WAITZKIN, H. - A marxist view of medical care. Ann. intern. Med., Philadelphia, (89):264-78, 1978.

WAKSMAN, S.A. - A vitória sobre a tuberculose: de Hipócrates à estreptomicina. São Paulo, Cultrix, 1964 .

WEBER, M. - A política como vocação. In: - Ensaios de sociologia. Rio de Janeiro, Zahar, 1964. p.97-153. WEBER, M. - Parlamentarismo e Governo numa Alemanha reconstruída: uma contribuição à crítica do funcionalismo e da política partidária. In: - Textos selecionados. 
3ạ ed. São Paulo, Abril Cultural, 1985. p.1-83.

WEFFORT, F.C. - Participação e conflito industrial. Contagem e Osasco, 1968. São Paulo, CEBRAP, 1972. (Cadernos CEBRAP, 5). 